\title{
Ceza Muhakemesi Hukukunda Moleküler Genetik İncelemelerin Özel Nitelikli Kişisel Verilerin Korunması Açısından Değerlendirilmesi
}

\author{
Evaluation of Molecular Genetic Analysis in Criminal Procedure Law \\ in Terms of Protection of Sensitive Personal Data
}

\section{Ayşe Özge ATALAY' (i)}

${ }^{1}$ Av. Dr., İstanbul Barosu, İstanbul, Türkiye

ORCID: Ö.A. 0000-0001-6969-5312

\section{öz}

Kişisel verilerin korunması, büyük bir önem ve ihtiyaç arz etmekle birlikte, günümüzde hem kişisel veri kapsamına giren unsurların hem de bu verilerin korunması bağlamında hukuka aykırılık teşkil edebilecek durumların çeşitlenmesi, korumayı zorlaştırmakta ve hukuki açıdan yeni koruma imkânlarının oluşturulması gerekliliğini doğurmaktadır. Ceza muhakemesi hukuku, niteliği itibarıyla kişisel verilere en çok ihtiyaç duyan hukuk alanını teşkil etmektedir. 5271 sayılı Ceza Muhakemesi Kanunu'nun 78 ve devamı maddelerinde düzenlenen moleküler genetik incelemeler de bu kapsamda özel nitelikli kişisel verileri konu edinmektedir. Üstelik ülkemiz açısından kurulup kurulmaması yönünde tartışmalar bulunsa da, çoğu ülke açısından DNA veri bankalarının mevcudiyeti, özel nitelikli kişisel verilerin korunması konusunda farklı değerlendirmeler yapılmasını gerektirmektedir. Çalışmamızda, ceza muhakemesi hukukunda moleküler genetik inceleme yöntemi, özel nitelikli kişisel verilerin korunması açısından incelenmiş ve öncelikle Türk ceza muhakemesi hukukuna, daha sonra ise önemli mukayeseli hukuk örneklerine yer verilmiştir. Bu uğurda, moleküler genetik inceleme yöntemine ilişkin yasal düzenlemeler, bu düzenlemelerde öngörülen koruma mekanizmaları ve uygulamaya yansıyan durumlar üzerinde durulduktan sonra, yargı kararlarında ele alınan hususlara da değinilmiştir. Konuya ilişkin olarak tespit edilen bazı önemli noktalar ve özellikle de ülkemizde bir ulusal DNA veri bankası kurulması gerekip gerekmediği hususundaki açıklamalar ile birlikte bir takım öneriler sunularak çalışma tamamlanmıştır.

Anahtar Kelimeler: Moleküler genetik inceleme, Özel nitelikli kişisel verilerin korunması, DNA veri bankası

\section{ABSTRACT}

Although the protection of personal data is a requirement and has a great importance, the diversification of both the data within the scope of personal data and the situations that may cause a violation of the law in terms of protection of this data, makes this protection difficult and necessitates the creation of new legal protection mechanisms. Criminal procedure law is the branch of law which most needs personal data. Molecular genetic analysis is regulated by Articles 78 and thereafter of the Turkish Criminal Procedure Code No. 5271 which is focused on sensitive personal data. Although there are debates on whether or not they should be established in our country, DNA data banks in most countries require different evaluations on the protection of sensitive personal data. In our study, molecular genetic analysis in criminal procedure law is examined in terms of the protection of sensitive personal data and examining firstly Turkish criminal procedure law and then significant comparative law examples. In this regard, the legal regulations related to molecular genetic analysis, the protection mechanisms envisaged in these regulations and the situations reflected in practice are presented and the issues discussed in the judicial decisions are also mentioned. The study was completed by presenting certain important points related to the subject and with specific explanations on whether or not a national DNA database should be established in our country.

Keywords: Molecular genetic analysis, Protection of sensitive personal data, DNA databank

Submitted: 29.07.2019 • Revision Requested: 06.08.2019 • Last Revision Received: 02.10.2019 • Accepted: 03.10.2019 •

Published Online: 12.11.2019

Corresponding author: Ayşe Özge Atalay, E-mail: aysemulder@gmail.com 


\section{EXTENDED ABSTRACT}

If we placed all of our personal data in a circle, the information coming from a molecular genetic analysis of our DNA would be located at the center point. This centre point symbolizes our sensitive personal data.

Compared with other branches of law, criminal procedural law is the branch of law which most needs personal data and therefore performs the most interventions in accordance with its proceedings. Moreover, data in the category of sensitive personal data has a great importance in terms of criminal procedure. Since DNA samples cannot be manipulated and provide results with close to 100 percent accuracy, they offer a valuable type of evidence in terms of revealing the material truth. Depending on the offense committed, the molecular genetic analysis method therefore constitutes an important approach in the investigation and prosecution phases of criminal procedure, as being a method of reading the markers expressed in DNA data.

Making use of DNA samples is important for criminal procedural law, but it requires using sensitive personal data. For this reason, the need for protecting sensitive personal data should be taken into consideration from the very beginning of the criminal procedure through to the conclusion. In this study, the molecular genetic analysis method in criminal procedural law will be evaluated, especially with regard to the protection of personal data. To this end, firstly the definition of personal data and the classification of specific personal data will be given and subsequently the legal provisions in Turkish criminal procedural law will be examined in detail. As will be seen, in terms of molecular genetic analysis, there are important provisions in the Turkish legislation regarding the protection of personal data. The most important one of these provisions is allowing the application of this method only in cases of where a judge renders a decision based on essentiality. In addition to specifically regulating confidentiality, the objectivity of the expert who makes this analysis and the destruction of the samples used in the analysis have also been regulated.

After the evaluation of Turkish legislation, views on the possibility of establishing a national DNA data bank in Turkey, will be discussed. In this regard, opinions in the doctrine shall be presented and the obsolete draft Act on a national DNA data bank in Turkey will be explained.

After this comprehensive analysis of the Turkish law, the next topic will be the 
regulation of molecular genetic analysis in comparative law. In that context, since the related Articles of the Turkish Criminal Procedure Code (CPC) have been translated from the German Criminal Procedure Code (StGB), the first country to be compared will be Germany. In this way, to avoid repeating the same provisions, two different methods will be explained which are regulated in the StGB but which do not appear in the CPC. These are: mass DNA analysis and data storage used for future criminal procedures. In other words a DNA data bank.

The second country to be examined after Germany is the United Kingdom. This is because until the ECtHR's famous decision in the Case of S. and Marper v. the United Kingdom this country had implemented a highly controversial system. Until this decision, the United Kingdom kept DNA cell samples for an indefinite period. Since this kind of application constitutes a very serious interference to the right to privacy regulated in Article 8 of ECHR, the ECtHR ruled against the United Kingdom, and the country made some amendments to its domestic law.

Following the United Kingdom, the United States of America will be examined due to it having the largest DNA data bank in the world. This DNA data bank, named CODIS, is used by the FBI. Subsequently, other countries such as France, Italy and Canada (where national DNA data banks have existed for a long time) will be examined, and the different features of the practices in these countries will be explained.

In the conclusion, a general evaluation and some important suggestions will be made which should be taken into consideration in case of the establishment of a national DNA data bank in Turkey. In this context, countries that have the most positive practices regarding the protection of personal data will be given as examples. Thus, the recommendations will be given for reaching and even going beyond the levels of international standards.

\section{Giriş̧}

Kişisel verilerin korunması, çağımızda şüphesiz ki çok büyük bir önem arz etmektedir. Zira kişisel nitelikteki bilgiler, kişisellik mevhumunun önemine binaen, şahıslar açısından taşıdı̆̆ hizmetler bakımından devletler ve kurumları açısından değer taşımakta, ticari amaçlı şirketler bakımından çoğunlukla bir gelir kaynağı olarak görülmekte, hatta sırf merak uyandırma özelliğinden kaynaklı olarak herhangi üçüncü kişiler açısından dahi önemli 
bir cazibe unsuru teşkil etmektedir. Kişisel verilerimizi hedef alan tüm bu kitle karşısında, onları koruyabilmek oldukça hassas bir boyut kazanmaktadır. Üstelik yıllar geçtikçe özellikle her alanda yaşanan teknolojik gelişmelerle birlikte, bir kişiye ait verilerin sayısında, bunlara ulaşma yöntemlerinde ve hâliyle korunmalarına ilişkin zorluklar açısından da artış ve değişmeler olmaktadır.

Zaman ilerledikçe yüzeysel anlamda çeşitlenmekle birlikte kişisel veriler, hep var olan ve değişmeyen, ancak zaman ilerledikçe kullanılmaya başlanan farklı teknikler ile yeni bilgilere erişilmesini sağlayan bir öze de ilişkin olmaktadır. Bu kapsamda, belki birkaç yıl evvel var olmayan IBAN'ımız, ulaşım kartı numaramız veya sosyal medyada yer alan profil fotoğrafımız da, dün ebeveynlerimizin, bugün geçireceğimiz kalıtımsal hastalıkların, yarın hakkımızda başka bilgilerin öğrenilebilir hâle gelmesini sağlayan DNA örneklerimiz de kişisel veri kapsamında yer almaktadir.

Kişisel verilerimizin tümünün bir çember içinde toplandığını düşünürsek, merkez noktasına doğru ilerledikçe verilerin niteliği hassaslaştığından, korunma konusundaki beklenti de artış gösterecektir. Özellikle ceza muhakemesi hukuku işlemleri, süjelerinin kişisel verilerinin korunması konusunda herhangi bir ihlâl yaratılmamasına en çok dikkat edilmesini gerektiren hukuk dalını oluşturmaktadır. Çünkü özel yaşamın gizliliği hakkına müdahalenin en fazla olduğu ve en çok kişisel verinin toplandığı hukuk dalı, ceza muhakemesi hukuku olmaktadır. Çalışma konumuzu teşkil eden moleküler genetik incelemeler yoluyla elde edilen kişisel veriler de kişisel verilerimizden oluşan dairenin merkezinde yer aldığından, ceza muhakemesi hukukunun kişisel veriler ile ilişkisi bakımından hassas bir alan teşkil etmektedir.

Çalışmamızda, ceza muhakemesi hukuku kapsamında moleküler genetik inceleme yöntemi, özel nitelikli kişisel verilerin korunması bağlamında değerlendirilecektir. Bu uğurda evvela, kişisel verilerin tanımına, kapsamına ve özel nitelikli kişisel veri ayrımına yer verildikten sonra, moleküler genetik incelemelerin hukuki niteliği, mevzuattaki düzenleniş şekli ve yargı tarafından yapılan değerlendirmeler, öncelikle Türk hukuku açısından daha sonra ise mukayeseli hukuk örnekleri bakımından ele alınacaktır. Hukuki düzenleme ihtiyacı bulunan alanlara ve mevcut düzenlemeler çerçevesinde daha fazla korumayı gerektiren hususlara değinildikten sonra, mevcut veya muhtemel temel hak ihlâlleri ve bunlar karşısında yapılması gerekenlere dair çözüm önerileri sunulacaktır. 


\section{Kișisel Veri Kavramı}

\subsection{Tanım}

Kişisel verinin ne olduğuna ilişkin değişik tanımlar yapılabilecek olsa da, uluslararası niteliği olan özlü bir tanım benimsemek adına, Avrupa Konseyi tarafından öngörüldüğü şekilde ifade edersek "kimliği belirli veya belirlenebilir gerçek bir kişiye iliş̧kin her türlü bilgi" kişisel veri oluşturmaktadır. Tek başlarına ele alındıklarında bu niteliği taşımasalar da, şayet farklı bilgi parçaları bir araya getirildiklerinde belirli bir kişinin tanınmasına yol açıyorsa, bu takdirde söz konusu farklı bilgi parçaları da kişisel veri niteliğini haiz olarak kabul edilmektedir. Bu bağlamda, bir kişinin ismi, soy ismi, telefon numarası, kimlik numarası gibi bilgiler kişisel veri kapsamında kabul edilirken niteliği gereği kamuya açık olan bir şirketin ticaret sicil numarası yahut herhangi bir anonimleşmiş bilgi kişisel veri kapsamına girmemektedir. ${ }^{1}$

Avrupa Konseyi’nin benimsediği kişisel veri tanımıyla birlikte, doktrinimizde çok daha sade, ama bir o kadar da açıklayıcı bir başka ifade daha kullanılmak suretiyle kişisel veri, "biz'e ilişkin olan pek çok bilgi"” şeklinde de nitelendirilmektedir. Gerçekten de bizi biz yapan, adeta bir yapboz gibi fiziki varlığımızı ve şahsiyetimizi oluşturan bu verilerin korunması büyük önem arz etmekte, veri sahibinin rızası hilafına yahut bilgisi olmaksızın başka kişilerce öğrenilmesi, saklanması veya işlenmesi o kişinin temel hak ve özgürlükleri açısından maruz kaldığı ağır bir ihlâl anlamına gelmektedir.

Her ne kadar kişisel verilerin korunması henüz müstakil bir hak olarak tanınmıyor olsa da, şüphesiz ki bu verilerin özel yaşam ile yakından ilişkili olması, konunun özel yaşamın gizliliği hakkı kapsamında değerlendirilmesini gerektirmektedir. ${ }^{3} \mathrm{Bu}$ bakımdan, Avrupa İnsan Hakları Sözleşmesi (AİHS) md. 8 (özel hayata ve aile hayatına sayg1 gösterilmesi hakkı) ve iç hukuk bakımından Türkiye Cumhuriyeti Anayasası md. 20 (özel hayatın gizliliği), kişisel verilerin konu olduğu herhangi bir ihlâl durumunda, özel yaşamın gizliliği hakkı üzerinden koruma sağlayacak olan yasal düzenlemeleri teşkil etmektedir. Üstelik 2010 yılında yapılan değişiklik ile Anayasa md. 20'ye eklenen 3'ncü fikrada yer alan düzenleme, her ne kadar özel hayatın gizliliği başlığı altında yer alsa da, kişisel verilere ayrı bir önem verildiğinin

$1<$ https:/ec.europa.eu/info/law/law-topic/data-protection/reform/what-personal-data_en>accessed 13 July 2019.

2 Elif Küzeci, Kişisel Verilerin Korunması (Turhan Kitabevi, Ankara 2010) 1.

3 Doğan Kılınç, ‘Anayasal Bir Hak Olarak Kişisel Verilerin Korunması’ (2012), 61 (3) AÜHFD 1099. 
kanıtı olmaktadır. Buna göre; "Herkes, kendisiyle ilgili kişisel verilerin korunmasını isteme hakkına sahiptir. Bu hak; kişinin kendisiyle ilgili kişisel veriler hakkında bilgilendirilme, bu verilere erişme, bunların düzeltilmesini veya silinmesini talep etme ve amaçları doğrultusunda kullanılıp kullanılmadığını öğrenmeyi de kapsar. Kişisel veriler, ancak kanunda öngörülen hâllerde veya kişinin açık rızasıyla işlenebilir. Kişisel verilerin korunmasına ilişkin esas ve usuller kanunla düzenlenir. ” (AY md. 20/3). Kanaatimizce, bu düzenleme ile Anayasamız, kişisel verilerin korunması gerekliliğini açıkça zikretmek suretiyle, AİHS ile mukayese edildiğinde çok daha nitelikli bir hükme yer vermiş olmaktadır. Elbette ki, bu hakkın yalnızca ismen zikredilmesi onun anayasal düzeyde korunması için yeterli olmadığından, kişisel verilerin korunmasına ilişkin kanun ile uluslararası standartların sağlanması, hatta bunların ilerisine geçilmesi gerekmektedir.

Anayasal bir hak olan kişisel verilerin korunması hakkı konusunda Anayasa Mahkemesi’nin görüşleri de elbette büyük bir önem taşımaktadır. Anayasa Mahkemesi bir kararında, 5237 s. TCK md. 136' da yer alan kişisel verileri hukuka aykırı olarak ele geçirme ve yayma suçundan açılan kamu davasında, ceza mevzuatında kişisel verilerle ilgili bir tanım ve sınırlandırma yapılmadı̆̆ından, anılan kanun düzenlemesinin suçta ve cezada kanunilik ile belirlilik ilkelerine ve Anayasa md. 38'e aykırı olduğu iddiası üzerine inceleme yapmıştır. ${ }^{4}$ Anayasa Mahkemesi bu kararında, kişisel veri kavramının, belirli veya kimliği belirlenebilir olmak şartıyla, bir kişiye ilişkin bütün bilgileri ifade ettiğine dikkat çekmiştir. Bununla birlikte, zaman içinde kişisel veri kavramının anlam ve içeriğinin gelişip değişeceği hususunda kuşku bulunmadığını da belirterek "kişisel veri" kavramının teknolojik gelişmelere bağlı olarak çok farklı şekillerde ortaya çıkabileceğine vurgu yapmış ve bu kapsama giren tüm verilerin kanun koyucu tarafından öngörülebilmesi ya da tek tek sayılabilmesinin mümkün olmadığının altını çizmiştir. Somut başvuru açısından ise, TCK md. 136 düzenlemesinde suç olan hareketin ve yaptırımının açıkça gösterilmiş olması nedeniyle, başvuru konusu edildiği şekilde herhangi bir anayasal ihlâl bulunmadığına hükmetmiştir.

Avrupa Konseyi üyesi ülkeler tarafından imzalanan, Kişisel Verilerin Otomatik İşlenmesine İlişkin Olarak Bireyin Korunması Hakkındaki Sözleşme ${ }^{5}$ ise, kişisel

4 Anayasa Mahkemesi'nin 2015/32 E 2015/102 K sayılı ve 12/11/2015 tarihli karar1.

5 Convention for the Protection of Individuals with regard to Automatic Processing of Personal Data (ETS No 108) Sözleşmenin tam metni için bkz. <http://conventions.coe.int/Treaty/en/Treaties/Html/108.htm> accessed 13 July 2019. 
verilerin toplanmasına ve işlenmesine ilişkin suistimallere karşı koruyucu nitelik taşıyan ve bağlayıcı olan ilk uluslararası araç olma özelliğini taşımaktadır. Bu Sözleşme, esasen ülkemiz tarafından da 1981 yılında imzalanmış, ancak hayli uzun bir gecikme ile, 2016 y1lında onaylanmış ve yürürlüğe girmiştir. Yaşanan bu gecikmenin nedeni, ülkemiz nezdinde kişisel verilerin korunmasına ilişkin bir kanunun yürürlüğe girmesinin diğer ülkelere nazaran oldukça gecikmeli gerçekleşmiş olmasıdır. 6698 sayılı Kişisel Verilerin Korunması Kanunu, Türkiye'de 2016 yılında yürürlüğe girmiş ${ }^{6}$ ve bunun hemen ardından anılan Sözleşme de onaylanarak iç hukukumuzun bir parçası hâline gelmiştir.

Sözleşme'nin 2'nci maddesinde de kişisel veri, yukarıda yer verdiğimiz şekilde, "kimliği belirli veya belirlenebilir gerçek bir kişiye ilişkin her türlü bilgi" olarak tanımlanmaktadır. Görüldüğü üzere, gerek ulusal gerekse uluslararası metinlerde kişisel verinin tanımı bakımından müşterek bir yaklaşım sergilenmekte, kişisel veri kapsamına dâhil olan hususlar ise önceden belirlenemeyecek bir nitelik taşıdığından, yalnızca örneklendirme yoluyla açıklanmaktadır. Ancak kullanılan tanım, nelerin kişisel veri kategorisine girip nelerin girmediğini belirleyebilmek bakımından son derece fayda sağlamaktadır.

\section{2. Özel Nitelikli Kişisel Veri Ayrımı}

Kişisel veriler kapsamında yer alan bazı veriler, diğerlerine nazaran çok daha hassas bir nitelik arz etmektedir ve bir kademe daha fazla korunma ihtiyacına muhtaç olmaktadır. Kişisel Verilerin Otomatik İşlenmesine İlişkin Olarak Bireyin Korunması Hakkındaki Sözleşme de bazı kişisel verilerin bu açıdan özel olarak ele alınması gerektiğini kabul etmiştir. Sözleşme'nin “özel veri kategorileri” başlıklı 6'ncı maddesi uyarınca, iç hukukta uygun güvenceler sağlanmadıkça, ırk menşeini, politik düşünceleri, dini veya diğer inançları ortaya koyan kişisel nitelikteki veriler ile sağlık veya cinsel yaşamla ilgili kişisel nitelikteki veriler ve ceza mahkûmiyetleri otomatik bilgi işlemine tabi tutulamamaktadır.

6698 sayılı Kişisel Verilerin Korunması Kanunu'nda da tıpkı Sözleşme'de yer aldığı gibi, özel nitelikli veri hususu ayrı bir madde olarak düzenlenmiştir. Avrupa Konseyi tarafından belirlenen tanımları benimseyen ve Sözleşme ile paralel bir düzenleme arz eden Kanun'un 6'ncı maddesinde, özel nitelikli kişisel verilerin işlenme şartlarına yer verilmiş, ancak Sözleşme'ye nazaran daha geniş kapsamlı bi düzenleme

$6<$ http://www.mevzuat.gov.tr/MevzuatMetin/1.5.6698.pdf> accessed 23 July 2019. 
yapılmıştır. Buna göre, özel nitelikli kişisel verilerin tanımı ve işlenme şartları şu şekilde belirlenmiştir;

“(1) Kişilerin ırkl, etnik kökeni, siyasi düşüncesi, felsefi inancl, dini, mezhebi veya diğer inançlarl, kllık ve klyafeti, dernek, vaklf ya da sendika üyeliği, sağllğl, cinsel hayat, ceza mahkûmiyeti ve güvenlik tedbirleriyle ilgili verileri ile biyometrik ve genetik verileri özel nitelikli kişisel veridir.

(2) Özel nitelikli kişisel verilerin, ilgilinin açık rızası olmaksızın işlenmesi yasaktır.

(3) Birinci fikrada sayllan sağllk ve cinsel hayat dlşındaki kişisel veriler, kanunlarda öngörülen hâllerde ilgili kişinin açık rızası aranmaksızın işlenebilir. Sağlık ve cinsel hayata ilişkin kişisel veriler ise ancak kamu sağglığının korunması, koruyucu hekimlik, tıbbî teşhis, tedavi ve bakım hizmetlerinin yürütülmesi, sağlık hizmetleri ile finansmanının planlanması ve yönetimi amacıyla, sır saklama yükümlülüğ̈̈ altında bulunan kişiler veya yetkili kurum ve kuruluşlar tarafından ilgilinin açık rızası aranmaksızın işlenebilir.

(4) Özel nitelikli kişisel verilerin işlenmesinde, ayrıca Kurul tarafindan belirlenen yeterli önlemlerin alınması şarttır."

Doktrinde de kişilerin hücre örneklerinin, kişisel veri olmanın ötesinde, oldukça hassas bilgiler içeren, sağlığa ilişkin detaylar da sunan, kişiler arası genetik ilişkiler ile etnik kökenleri ortaya koyabilen ve kişinin benzersiz genetik kodunu içeren oluşumlar olduğuna dikkat çekilmektedir. ${ }^{7}$ Özellikle ceza muhakemesi hukuku açısından gerek suçların önlenmesi gerekse bir suçun işlenmesinin ardından soruşturma ve kovuşturma işlemleri kapsamında, hatta infaz aşamasında, aralarında kişiye ait hücre örneklerinin de yer aldığı, özel nitelikli pek çok kişisel verinin toplanması ve işlenmesi söz konusu olmaktadır. 5271 sayılı Ceza Muhakemesi Kanunu'nda 77 ila 80'nci maddeler arasında düzenlenmiş olan moleküler genetik incelemeler de 6698 sayılı Kanun md. 6/1'de açıkça ifade edildiği üzere, özel nitelikli kişisel verilerin kapsamında kalan hücre örneklerini konu almaktadır ve özel nitelikli kişisel verilerin korunması bakımından iç hukukta sağlanacak güvencelerin varlığı bu nedenle konu bakımından büyük önem taşımaktadır.

Ceza muhakemesi hukuku kapsamında moleküler genetik inceleme yönteminin uygulanabilmesi amacıyla bir kişinin vücudundan örnek alındığı durumlar, Anayasamızın kişi dokunulmazlığının düzenlendiği 17 'nci maddesi açısından da değerlendirme 
yapılmasını gerektirmektedir. Anayasa md. 17, tıbbi zorunluluklar ve kanunda yazılı hâller dışında, kişinin vücut bütünlüğüne dokunulamayacağı, rızası olmadan bilimsel ve tıbbî deneylere tabi tutulamayacağını hüküm altına almaktadır. Yukarıda açıklandığı üzere, ceza muhakemesi hukuku amaçları çerçevesinde moleküler genetik inceleme yöntemine başvurulması, kanun ile düzenlenmiş yasal bir dayanağa sahip olduğundan, Anayasa'ya herhangi bir aykırılık teşkil etmemektedir. Yasal bir dayanak bulunmaksızın veya mevcut yasal dayanağa aykırı şekilde hareket etmek suretiyle şüpheli veya sanık da olsa bir kimsenin vücut bütünlügüne yönelik olarak gerçekleştirilen müdahaleler ise hukuka aykırılık teşkil edecektir. ${ }^{8}$

Ayrıca şunu da belirtmek gerekir ki, moleküler genetik incelemelerin temel amacı, hücre örneği alınan bireyin genetik özelliklerine ulaşmak, herhangi bir hastalık ya da karakteristik durumunu tespit etmek değil, onun suç mahalli veya mağdur ile olan ilişkisini ortaya koyabilmektedir. Bu açıdan bakıldığında, moleküler genetik inceleme yönteminin başlı başına insan onuruna aykırı bir müdahale teşkil ettiği söylenemeyecektir.9 Ancak tabii ki önemli olan, kanunla düzenlenmiş, evrensel hukuk ilkelerine bağlı bir yöntemin uygulanmasını sağlamaktır. Bunun aksi bir uygulama, işlemi hem insan onuruna aykırı hem de temel hak ve özgürlükleri ihlal eder hâle dönüştürecektir. Zira moleküler genetik inceleme yöntemiyle bireyin adeta genetik şifresi çözülmektedir ve bu yöntemin kötüye kullanılmasının önüne geçmek zor, ancak aynı zamanda çok da önemli olduğundan, bu uygulamaya imkân sağlayan hükümlerin en ince ayrıntısına kadar düşünülüp yasalaştırılması ihtiyacı bulunmaktadır. ${ }^{10}$

Özel nitelikli kişisel verilerin korunması açısından gerek duyulan koruma mekanizmalarının sağlanıp sağlanamadığını, eksik ve aksayan yanların neler olduğunu ve bunlara ilişkin yapılması gerekenleri belirtmeden evvel, moleküler genetik inceleme yönteminin ifade ettiği hususları ortaya koyabilmek adına, bu kavramı daha yakından incelemek gerekmektedir. Bu doğrultuda, aşağıda öncelikle Türk ceza muhakemesi hukukunda, ardından ise mukayeseli hukukta moleküler genetik inceleme yöntemine ilişkin olarak yer alan yasal düzenlemelere ve uygulamalara dair bazı açıklamalara yer verilecektir.

8 Özge Apiş, 'Ceza Muhakemesi Hukukunda Şüpheli/Sanığın Beden Muayenesi ve Vücudundan Örnek Alınması' (2012) 18 (1) MÜHFHAD 293.

9 Veli Özer Özbek, CMK İzmir Şerhi, (Seçkin Yayıncılık, Ankara 2005) 277.

10 Ibid 278, dipnot 128. 


\section{Türk Ceza Muhakemesi Hukukunda Moleküler Genetik İncelemeler}

\subsection{Genel Olarak}

Öncelikle, doktrinimiz açısından kavramsal birlik sağlanamadığını ve moleküler genetik inceleme yöntemi için farklı isimlendirmeler kullanıldığını belirtmek isteriz. $\mathrm{Bu}$ yönde doktrindeki bir görüş, DNA analizinin, moleküler genetik bir araştırma olduğunu belirterek en uygun ifadenin "adli DNA analizi" olduğunu savunmuştur. ${ }^{11}$ Bu görüşe hak vermekle birlikte, kanunda yer alan ifadeyi kullanmayı tercih ettiğimizi, bu nedenle "moleküler genetik inceleme" kavramı ile devam edeceğimizi, "DNA analizi” kavramını ise eş anlamlı olarak kullanacağımızı belirtmek isteriz.

Şüphesiz ki ceza muhakemesi açısından deliller büyük bir önem taşımaktadır. Sağlkklı bir muhakeme süreci, toplanan deliller ile beslenerek gelişmektedir. Deliller kapsamında, özellikle de tahrip edilme veya değiştirilme olanağı bulunmamasından ötürü net sonuçlara ve suç faillerine doğrudan ulaşılmasını sağlayan, insan vücudundan elde edilen deliller büyük değer kazanmaktadır. Bu kapsamda değerlendirilen moleküler genetik inceleme sonuçları da ceza yargılamasının neticelenmesi açısından belirleyici hususları ortaya koymaktadır. Moleküler genetik inceleme olarak adlandırılan husus, esasen DNA analizlerini ifade etmektedir ve elde edilen bu bilimsel deliller üzerinde yapılan analizlerden \%100'e yakın netlikte sonuçlara varılabilmektedir. DNA analizi sonucu profil çıarma yöntemi, İngiliz bilim insanı Alec Jeffreys tarafından keşfedilmiştir ve DNA profili esasen kişinin genetik kimliğini belirleyen, tek yumurta ikizleri hariç olmak üzere, her insanın kendine özgü olma niteliği taşıyan bir olguyu ifade etmektedir. ${ }^{12}$

DNA analizi yöntemiyle varılan sonuçların önemi çok büyüktür. ${ }^{13}$ Çünkü bu veriler, diğer delil türlerine nazaran çok daha doğru sonuçlara ulaşılmasına rehberlik etmektedir. Zira örneğin, olay yerinde bulunan parmak izleri ile mukayese yapılması imkânını ortadan kaldırmayı amaçlayan bir failin, asit kullanarak kendi parmak izlerini yok etmesi olasılık dâhilindedir, ancak buna mukabil, DNA analizi suretiyle failin saç,

11 Gülsüm Ayhan Aygörmez Uğurlubay, 'Almanya, İsviçre ve Avusturya Hukuku Bağlamında Türk Ceza Muhakemesi Hukukunda Adli DNA Analizleri’ (2017) 5 (2) Ceza Hukuku ve Kriminoloji Dergisi (Journal of Penal Law and Criminology) 37-39.

12 Oğuz Polat, Klinik Adli Tıp, (Seçkin Yayıncılık, Ankara 2007) 490; Bahri Öztürk and others, Nazari ve Uygulamalı Ceza Muhakemesi Hukuku (Seçkin, Ankara 2018) 339; Yener Ünver and Hakan Hakeri, Ceza Muhakemesi Hukuku (Adalet Yayınevi, Ankara 2018) 281.

13 Tarihsel süreç içinde, şüphelilerin olay yerinde bulunan kan lekelerinin boya olduğunu iddia etmelerinden başlanarak, kanın bir insana mı yoksa bir hayvana mı ait olduğunun belirlenmesinden, hangi insana ait olduğunun belirlenebilmesine uzanan bir ilerleme kaydedilmiştir. Öztürk, Tezcan, Erdem et al (n 13) 338. 
tırnak, deri parçası gibi dokularının yahut kanının incelenmesi, değiştirilmesi mümkün olmayan net sonuçlara varmayı sağlayacaktır. ${ }^{14}$ Tabiidir ki, bir kişinin görünüşünü yahut el yazısını değiştirmesi, hatta yukarıda ifade edildiği üzere, kendi parmak izlerine dahi müdahale etmesi mümkün iken, üstelik her yüzeyde parmak izi kalmazken, kişinin kendisine ait olan ve DNA analizi yapılmasına müsait dokularında herhangi bir değişiklik yapması mümkün olmayacaktır.

Şunu da belirtmek önemlidir ki, DNA analizi bakımından dikkat edilmesi gereken önemli bir husus bulunmaktadır: Negatif çıkan sonucun örnek sahibi kişinin fail olmadığını kesinlikle gösterdiğinin kabul edilmesine rağmen, pozitif çıkan neticelerin mahkûmiyet için tek başına yeterli olmayacağının dikkate alınması gerekmektedir. ${ }^{15}$ $\mathrm{Bu}$ bakımdan, moleküler genetik inceleme sonuçları, her zaman için suçlayıcı nitelik taşımamakta, aynı zamanda bir kişinin masumiyetinin ispatlanması bakımından da önem taşımaktadır. ${ }^{16}$

Moleküler genetik inceleme yönteminin hukuki niteliği açısından doktrinde farklı görüşler yer almaktadır. Bunun, ceza muhakemesi hukukunda bağımsız bir tedbir olmayıp aslında beden muayenesinin bir parçası, keşif veya olay yeri incelemesinin bir uzantısı olduğunu savunanlardan ${ }^{17}$ biri olan Özbek'e göre, moleküler genetik incelemelerin kendine özgü bir niteliği ve iki farklı yönü bulunmaktadır. Çünkü bu inceleme, hâkim bakımından bir keşif, analizi uygulayacak doktor veya yetkili bakımından ise bir bilirkişi incelemesi niteliği taşımaktadır. ${ }^{18}$ Başka bir görüş tarafından moleküler genetik inceleme yöntemi, beden muayenesinin bir biçimi olarak görülmektedir. ${ }^{19}$ Doktrindeki bir diğer görüş ise, bu incelemelerin bir koruma tedbiri olarak nitelendirilmesinin yanlış olmayacağını belirtmektedir. ${ }^{20}$ Kanaatimizce ise, beden muayenesi ve moleküler genetik incelemeler birbirlerinden farklı işlemler olduğundan, moleküler genetik incelemenin, beden muayenesinin bir şekli olduğunu

14 Ibid 339.

15 Ünver and Hakeri (n 13) 281.

16 Mark Alexander Zöller and Diana Thörnich, 'Rechtliche Möglichkeiten und Grenzen der Ausweitung von DNA-Analysen im Strafverfahren' (2017) 6 ZIS 331.

17 Veli Özer Özbek, 'Ceza Muhakemesi Hukukunda DNAAnalizi', <http://www.hukuki.net/ www.saglikhukuku. net/bilgi/a044.asp> accessed 14 July 2019; Fatih Selami Mahmutoğlu, 'Moleküler Genetik İncelemenin Ceza Yargılaması Hukuku Bağlamında Analizi', <http://fsmahmutoglu.av.tr/ pdf/27b485a20728432f3c6b2f169f7a8f80c62998517818071225.pdf > accessed 21 July 2019.

18 Veli Özer Özbek, 'Tıp Ceza Hukukunda DNA İncelemesi', v. Türk-Alman Tip Hukuku Sempozyumu-Tip Ceza Hukukunun Güncel Sorunları (Türkiye Barolar Birliği Yayınları, Ankara 2008) 1088.

19 Ünver and Hakeri (n 13) 281.

20 Aygörmez Uğurlubay (n 12) 40; Mahmutoğlu (n 18) 3. 
söylemek mümkün olmayacaktır. Ancak bizce, beden muayenesi adeta moleküler genetik incelemenin "zımni ön koşulu" niteliği taşımaktadır. Zira beden muayenesi hükümleri çerçevesinde hücre örnekleri alınmadan, moleküler genetik inceleme yapılması mümkün olmayacaktır.

Moleküler genetik incelemeler, bir yandan kriminal vakaların aydınlatılmasını sağlamakta iken diğer yandan toplanan bulguların özel nitelikli kişisel veri kategorisinde yer alması, yapılacak işlemler bakımından hassas bir duruma yol açmaktadır. Bu bağlamda en çok üzerinde durulan husus, saklanan verilerin veya DNA örneklerinin kötüye kullanımının mümkün olup olmayacağıdır. ${ }^{21}$ Gerçekten de ceza muhakemesi işlemlerinde, maddi gerçeğe ulaşma hedefi ile bireyin korunması şeklindeki iki önemli menfaat çatışmaktadır. Günümüzün modern ceza muhakemesi hukuku anlayışı çerçevesinde, her ne olursa olsun maddi gerçeğe ulaşma gayesi terk edildiğinden, kişilerin temel hak ve hürriyetlerine verilen önem ağırlık kazanmıştır. ${ }^{22}$ Üstelik, yalnızca bu anlayış nedeniyle değil, başlı başına biyoteknolojinin günümüzde eriştiği düzey, insan onurunu korumak adına yeni hakların güvence altına alınmasını veya mevcut hakların ek güvenceler ile desteklenmesini gerektiren bir tablo ortaya koymaktadır. ${ }^{23}$ Bir yandan mağdur ve suçtan zarar gören kişilerin ya da bunların belli kişiler olmaması durumunda toplumun, diğer yandan ise şüpheli veya sanık konumundaki kişilerin haklarının korunması ihtiyacı bulunmaktadır. Birbiriyle çatışan menfaatler arasında gereken dengenin kurulması için özgürlüklerin en önemli ve belki de tek güvencesi olarak, ceza hukukunun tüm demokratik ilkelere bağlılık ile işletilmesi ihtiyacı bulunmaktadır. ${ }^{24}$

\section{2. İlgili Yasal Düzenlemeler}

1412 sayılı mülga CMUK' da yer almayan moleküler genetik incelemeler, 5271 sayılı Ceza Muhakemesi Kanunu'nda 3 madde hâlinde düzenlenmektedir. Bunlar; moleküler genetik incelemeler başlıklı 78'nci madde ${ }^{25}$, hâkimin kararı ve inceleme yapılmasını

21 İbrahim Semizoğlu, Adli DNA Analizleri (Adalet Yayınevi, Ankara 2013) 325.

22 Hakan Kızılarslan, 'Hukuka Aykırı Delil Açısından Vücudun Muayenesi ve Örnek Alma İşlemleriyle İlgili 5271 S. CMK Düzenlemesi ve Uygulamada Sorunlar', Ceza Muhakemesi Kanununun 3 Yılı (TCHD Yayınları No 11, İstanbul 2009) 319.

23 Oktay Uygun, Kamu Hukuku İncelemeleri (XII Levha Yayıncılık, İstanbul 2011) 71.

24 Ahmet Mumcu and Elif Küzeci, İnsan Hakları ve Kamu Özgürlükleri (Turhan Kitabevi, Ankara 2011) 138.

25 Madde 78 - (1) 75 ve 76 ncı maddelerde öngörülen işlemlerle elde edilen örnekler üzerinde, soybağının veya elde edilen bulgunun şüpheli veya sanığa ya da mağdura ait olup olmadığının tespiti için zorunlu olması hâlinde moleküler genetik incelemeler yapılabilir. Alınan örnekler üzerinde bu amaçlar dışında tespitler yapılmasına yönelik incelemeler yasaktır. (2) Birinci fikra uyarınca yapılabilen incelemeler, bulunan ve kime ait olduğu belli olmayan beden parçaları üzerinde de yapılabilir. Birinci fikranın ikinci cümlesi, bu hâlde de uygulanır. 
düzenleyen 79 'ncu madde ${ }^{26}$ ve genetik inceleme sonuçlarının gizliliğine ilişkin olan 80 'nci maddedir. ${ }^{27}$ Ancak bu maddeler kapsamında düzenlenen moleküler genetik incelemelerin yapılabilmesi için elde edilmesi gereken hücre örnekleri, CMK md. 75 (şüpheli veya sanığın beden muayenesi ve vücudundan örnek alınması) ve md. 76'da (diğer kişilerin beden muayenesi ve vücuttan örnek alınması) öngörülen işlemler yoluyla elde edildiğinden, konuyla bağlantılı tüm hususlara değinebilmek adına hem bu maddeleri hem de Ceza Muhakemesinde Beden Muayenesi, Genetik İncelemeler ve Fizik Kimliğin Tespiti Hakkında Yönetmelik ${ }^{28}$ hükümlerini irdelemek ihtiyacı bulunmaktadır.

Her ne kadar moleküler genetik incelemelere ilişkin hususlar esasen CMK' da düzenlenmiş olsa da, bu incelemelerin kapsamına ya da herhangi bir tanımına yer verilmemiştir. Moleküler genetik incelemenin tanımı, Ceza Muhakemesinde Beden Muayenesi, Genetik İncelemeler ve Fizik Kimliğin Tespiti Hakkında Yönetmelik’te yapılmıştır. Buna göre, moleküler genetik inceleme; gereken tür ve miktardaki biyolojik materyali kullanarak, kişiyi diğer kişilerden ayıran ve kalıtım kurallarına uygun olarak aktarılan hastalık dışındaki özelliklerinin moleküler düzeyde araştırılmasını ifade etmektedir (md. 3). Bu yönetmelik ile, CMK'da yer alan beden muayenesi, fizik kimliğin tespiti ve moleküler genetik inceleme hususları ayrıntılı olarak düzenlenmiştir ve bu düzenlemeler, kanun hükümleri ile paralellik arz etmektedir.

Vücuttan örnek alma, bedene yapılan bir müdahale olmasına rağmen, beden muayanesinden farklı bir işlem niteliği taşımaktadır. Çünkü beden muayenesinde, muayene konusu şüpheli, sanık veya diğer kişilerin bedeni iken, vücuttan örnek alınmasında işlemin konusu alınan örnek olmaktadır. ${ }^{29}$ Dış beden muayenesi yapılabilmesi

26 Madde 79 - (1) 78 inci madde uyarınca moleküler genetik incelemeler yapılmasına sadece hâkim karar verebilir. Kararda inceleme ile görevlendirilen bilirkişi de gösterilir. (2) Yapılacak incelemeler için resmen atanan veya bilirkişilikle yükümlü olan ya da soruşturma veya kovuşturmayı yürüten makama mensup olmayan veya bu makamın soruşturma veya kovuşturmayı yürüten dairesinden teşkilât yapısı itibarıyla ve objektif olarak ayrı bir birimine mensup olan görevliler, bilirkişi olarak görevlendirilebilirler. Bu kişiler, teknik ve teşkilât bakımından uygun tedbirlerle yasak moleküler genetik incelemelerin yapılmasını ve yetkisiz üçüncü kişilerin bilgi edinmesini önlemekle yükümlüdürler. İncelenecek bulgu, bilirkişiye ilgilinin adı ve soyadı, adresi, doğum tarihi bildirilmeksizin verilir.

27 Madde 80 - (Değişik 25/5/2005 - 5353/4 md) (1) 75, 76 ve 78 inci madde hükümlerine göre alınan örnekler üzerinde yapılan inceleme sonuçları, kişisel veri niteliğinde olup, başka bir amaçla kullanılamaz; dosya içeriğini öğrenme yetkisine sahip bulunan kişiler tarafından bir başkasına verilemez. (2) Bu bilgiler, kovuşturmaya yer olmadığı kararına itiraz süresinin dolması, itirazın reddi, beraat veya ceza verilmesine yer olmadığı kararı verilip kesinleşmesi hâllerinde Cumhuriyet savcısının huzurunda derhâl yok edilir ve bu husus dosyasında muhafaza edilmek üzere tutanağa geçirilir.

28 Resmi Gazete Tarihi 01/06/2005, Sayıs1 25832.

29 Pervin Aksoy İpekçioğlu, 'Vücuttan Örnek Alma İşleminin Hukuki Niteliği ve Anayasaya Uygunluğu', Prof. Dr. Nur Centel’e Armağan (Beta Yayınları, İstanbul 2013) 1159. 
için şüpheli veya sanığa isnat edilen suç bakımından herhangi bir ayrıma gidilmemiştir. Ancak bir kişi üzerinde iç beden muayenesi yapılabilmesi, kişiden kan veya benzeri biyolojik örnekler ile saç, tükürük, tırnak gibi örnekler alınabilmesi için üst sınırı iki yıldan daha fazla hapis cezasını gerektiren bir suçun söz konusu olması gerekmektedir (CMK md. 75/5). Kişiye isnat edilen birden fazla suç bulunduğu durumlarda, her suçun bağımsız olarak değerlendirilmesi gerektiği, cezasının üst sınırı iki yıldan az hapis cezası gerektiren suçlar açısından bu tedbirin uygulanamayacağı belirtilmelidir. ${ }^{30}$

Bu düzenleme ile CMK, basit suçların soruşturulmasında ağır sonuçları olan bir müdahaleye izin vermemeyi amaçlamaktadır. Fakat herhangi bir engel bulunmaması nedeniyle, iki yıldan daha az hapis cezasını gerektiren bir suç bakımından da şüpheli veya sanığın aleyhine olan suç şüphelerinden kurtulmak üzere bizzat kendisinin hekim veya sağlık kuruluşuna başvurup beden muayenesi yaptırmak veya örnek vermek suretiyle, sonuçlarını mahkemeye delil olarak sunması da söz konusu olabilecektir. ${ }^{31}$ Böyle bir yöntem sayesinde hem kişinin suçsuzluğunu kanıtlaması hem de muhakemenin daha hızlı ve doğru bir şekilde sonuçlanmasına katkı sağlanması mümkün olabilecektir.

Hem CMK md. 75/3 hem de Beden Muayenesi Yönetmeliği md. 6/2'de belirtildiği üzere, vücuttan örnek alınması işlemi açısından yalnızca tabip veya sağlık mesleği mensubu kişiler yetkili kılınmıştır. Belirtilen bu kimseler dışındaki kişilerce işlemin gerçekleştirilmesi mümkün olmayacak, eğer mevzuata aykırı şekilde vücuttan örnek alımış ise, bu örnek üzerinde moleküler genetik inceleme yapılamayacaktır. Bu sayede kanun koyucu, işlemin mevzuata uygun şekilde gerçekleştirilmemesi durumunda, moleküler genetik inceleme yapılması yolunu kapatmış olmaktadır.

Son olarak şuna da dikkat çekilmelidir ki, CMK kapsamında yapılacak olan moleküler genetik incelemelerde, eldeki bulgular şüpheli ve sanığa ilişkin olabileceği gibi, bunların dışında kalan mağdur, tanık vb. kişilere ilişkin de olabilecektir.

Tüm bu genel hükümler dışında, konumuz bakımından önem arz eden esas husus, yasal düzenlemelerde, moleküler genetik inceleme yöntemi ve uygulanan işlemler

30 Fatih Selami Mahmutoğlu, 'Beden Muayenesi ve Vücuttan Örnek Alınması', < http://fsmahmutoglu.av.tr/ pdf/76b00da1de336791f454b4977f6319d9cdf4656d7818071225.pdf> accessed 14 July 2019; Örneğin, üst sınırı iki yıldan az hürriyeti bağlayıcı ceza gerektiren basit taksirle yaralama durumunda, mağdura çarpan aracın belirlenebilmesi için aracın üzerinden elde edilebilecek biyolojik örnekler ile mağdurdan alınacak örnekler karşılaştırılabilecektir, ancak aynı amaçla şüpheli kişiden örnek alınması mümkün olmayacaktır. Örnek için bkz. Necat Batur, 'Ceza Yargılamasında Moleküler Genetik İnceleme’ (2016) 126 TBB Dergisi 79.

31 Faruk Turhan, 'Ceza Muhakemesinde Beden Muayenesi ve Tıp Hukuku (Özellikle AİHM Kararları Işı̆̆ında Şüpheli veya Sanığın Zorla Muayenesi Konusunun Değerlendirilmesi)', in V. Türk-Alman Tıp Hukuku Sempozyumu-Tıp Ceza Hukukunun Güncel Sorunları (TBB Yayınları, Ankara 2008) 1043. 
neticesinde elde edilen sonuçlar bakımından, özel nitelikli kişisel verilerin korunması hususunda hangi tedbirlerin getirildiğini ve bunların ne şekilde uygulandığını ortaya koymaktır. Bu nedenle aşağıda özel nitelikli kişisel verilerin korunmasına ilişkin olarak düzenlenen hükümler ayrı başlıklar altında detaylı şekilde incelenecektir.

\section{3. Özel Nitelikli Kişisel Verilerin Korunmasına İlişkin Hükümler}

Moleküler genetik inceleme sonuçlarının özel nitelikli kişisel veri olma vasfını taşıdı ğ konusunda herhangi bir tereddüt bulunmamaktadır. Bu nedenle de 5237 sayılı TCK'da düzenlenen, kişisel verilere ilişkin suçların konusu bu tür veriler de olabilecektir. Yani, moleküler genetik inceleme sonuçlarının, kişisel verilerin hukuka aykırı olarak kaydedilmesi (TCK md. 135), verilmesi-yayılması-ele geçirilmesi (TCK md. 136) ve yasada gösterilen süreler içinde yok edilmemesi (TCK md. 138) suçlarına konu olması mümkündür. ${ }^{32}$ Üstelik, TCK md. 138'e 2014-6526 sayılı Kanun ile eklenen ikinci fikra bilhassa bu hususa ilişkin bir düzenleme içermektedir. Fıkraya göre; verileri yok etmeme suçunun konusunun, Ceza Muhakemesi Kanunu hükümlerine göre ortadan kaldırılması veya yok edilmesi gereken verilerden olması hâlinde, faile verilecek olan ceza bir kat artırılmaktadır. Bilgilerin verilmesi yasağına aykırı davranışları gerçekleştirenler, aynı zamanda TCK md. 285'de düzenlenen soruşturmanın gizliliğini ihlâl suçunu da işlemiş olacaklardır. ${ }^{33} 6698$ sayılı Kişisel Verilerin Korunması Kanunu da ilgili suçlar bakımından TCK hükümlerine atıf yapmakla yetinmiştir (md. 17), ancak md. 18 'de kişisel verilerin konu olabileceği kabahatleri ve yaptırımı olan idarî para cezalarını göstermiştir.

Bununla birlikte, bir suç işlendikten sonra fail hakkında yaptırım uygulamak yerine, henüz bir hak ihlâli gerçekleşmeden evvel, bunu önleyecek düzenlemelerin yapılması maksadıyla, özel nitelikli kişisel verilerin korunmasına ilişkin olarak moleküler genetik inceleme hükümleri kapsamında kanunda önemli bazı koşullar öngörülmüştür. Bunlara uyulması hâlinde, kişisel verilerin gizliliği korunmuş olacağından herhangi bir hak ihlâli de yaşanmayacaktır. Bu özel tedbirler; moleküler genetik inceleme yapılabilmesinin yalnızca sınırlı amaçlara bağlanması ve sadece zorunluluk durumunda gerçekleştirilebileceği, işlemin yapılabilmesi için hâkim kararının mevcudiyeti şartı ve örnekler üzerinde inceleme yapacak olan bilirkişiler açısından öngörülen şartların yanı sıra, inceleme sonuçlarının gizliliği ile örneklerin imhasının gerekliliğinin

32 Nur Centel and Hamide Zafer, Ceza Muhakemesi Hukuku (Beta, İstanbul 2018) 329.

33 Nurullah Kunter, Feridun Yenisey and Ayșe Nuhoğlu, Açıklamalı Ceza Muhakemesi Kanunu (Beta, İstanbul 2013) 698. 
düzenlemesi şekillerinde kendilerini göstermektedir. Kanuni düzenlemede yer alan ve aşağıda tek tek ayrıntılı olarak açıklanacak olan bu koşullara riayet edilmemesi durumunda, moleküler genetik inceleme yapılmış olsa dahi, bu incelemenin sonucu hukuka aykırı yöntemle elde edilmiş bir delil niteliği taşıyacak ve bu nitelikteki delillerin ceza muhakemesinde kullanılması elbette ki mümkün olmayacaktır. ${ }^{34}$

\subsubsection{Amaca Bağlılık Koşulu}

CMK md. 78 metninde belirtildiği üzere, sayılan amaçları gerçekleştirmek için elde edilen örnekler üzerinde, söz konusu bu amaçlar dışında tespitler yapılmasına yönelik incelemeler yasaklanmıştır. Kanunda belirli amaçlar ile sınırlı olarak düzenleme yapıldığından, soybağının incelenmesi ve elde edilen bulgunun şüpheli, sanık ya da mağdura ait olup olmadığının incelenmesi dışında kalan başka herhangi bir amaçla moleküler genetik inceleme yapılamayacaktır. ${ }^{35}$

Şuna da dikkat çekilmelidir ki, soybağına ilişkin moleküler genetik inceleme, yalnızca bir suçun aydınlatılması bakımından soybağının tespit edilmesinin gerekli olduğu hâllerde yapılabilecektir. Bu hâller örneğin, alt ve üst soy ilişkisinin nitelikli hâl sayıldığı suçlar ya da doğrudan doğruya soybağına yönelik suçlar olabilecektir. ${ }^{36}$ Bu nedenle, herhangi bir suç ile ilişkisi bulunmayan, hukuk muhakemesini ilgilendiren soybağı tespitleri açısından CMK md. 78'in uygulanması ve bu kapsamda moleküler genetik inceleme yapılması söz konusu olmayacaktır.

Kanun hükmü gereği amaca bağl1lık arandığından, moleküler genetik inceleme yönteminin, elde edilen örnek sahibinin kökeninin tespit edilmesi gibi bir işlemi yapmak amacıyla kullanılması imkânı bulunmamaktadır. Fakat doktrindeki bir görüş tarafından, işlenen suçun veya şüphelinin niteliği itibarıyla, bu vasfı taşıyan tespitlerin yapılmasının zorunlu olması durumunda, bunların da gerçekleştirilmesi ihtiyacı olduğu savunulmaktadır. ${ }^{37}$ Unutulmamalıdır ki, bu yöndeki bir yaklaşım kabul edildiği takdirde, soruşturma veya kovuşturma konusu olayın çözülmesi bakımından ilerleme kaydedilebilecek olsa da, böyle bir uygulamanın hayata geçirilebilmesi için, kanunilik ilkesi gereğince, öncelikle

34 Mehmet Gödekli, 'Türk Ceza Muhakemesinde Maddi Gerçeğe Ulaşmanın Ön Koşulu Olarak Hukuka Aykırı Delillerin Değerlendirilmesi Yasağı’ (2016) 65 (3) Ankara Üniversitesi Hukuk Fakültesi Dergisi 1827.

35 Doğan Soyaslan, Ceza Muhakemesi Hukuku (Yetkin Yayınevi, Ankara 2018) 274; Ahmet Gökcen, Murat Balcı, Mehmet Emin Alşahin and Kerim Çakır, Ceza Muhakemesi Hukuku (Adalet Yayınevi, Ankara 2018) 347; Ünver and Hakeri (n 13) 281.

36 Centel and Zafer (n 33) 328; Cumhur Şahin and Neslihan Göktürk, Ceza Muhakemesi Hukuku II (Seçkin Yayıncilik, Ankara 2019) 89.

37 Ünver and Hakeri (n 13) 282. 
kanun metninde bu şekilde bir düzenleme yapılması gerekmektedir. Aksi takdirde, şüphelinin kimliğini tespit etmek amacı ardına gizlenerek farkı amaçlarla da inceleme yapılması sonucu ortaya çıkabilecek ve düzenleme suistimal edilmiş olacaktır.

Moleküler genetik incelemelerin bir diğer özelliği, yalnızca insan vücudundan alınan örnekler ile sınırlı tutulmamış olmasıdır. Bu bakımdan, olay yerinde bulunan ve kime ait olduğu bilinmeyen beden parçaları üzerinde inceleme yapılması da olanaklı kılınmıştır. Özellikle bu gibi durumlarda, karşılaştırma materyali bulunamasa da elde edilen bulgunun insana $\mathrm{m} 1$ ait olduğu, eğer bir insana ait ise, bir kadına mı yoksa bir erkeğe mi ait olduğu, hatta bu kişinin saç rengi ve göz rengi gibi özellikleri ile ırksal özelliklerinin neler olduğunun belirlenmesi mümkün olacaktır. ${ }^{38}$ Elbette ki, bu şekilde yapılacak olan bir incelemede amaç yine mağdur, sanık veya şüphelinin kimliğini belirlemektir. ${ }^{39}$

Bir hususa daha dikkat çekmek gerekir ki, kimi zaman moleküler genetik inceleme yöntemi, muhakeme sonucunda maddi gerçeğin ortaya çıkarılması amacına hizmet etmekten ziyade, doğrudan doğruya ceza muhakemesine ilişkin kurumlarla da bağlantılı olabilmektedir. Örneğin, maktulün kardeşi olduğunu iddia eden ve bu nedenle kamu davasına katılma talebinde bulunan yabanc1 uyruklu bir kimsenin, bu talebinin değerlendirilebilmesi için DNA incelemesi yapılmaksızın eksik inceleme ile hüküm kurulması, Yargıtay CGK tarafından bir kararda bozma gerekçesi yapılmıştır. ${ }^{40}$

Amaca bağlılık koşulunun bir diğer anlamı da, moleküler genetik inceleme sonucunda elde edilen kişisel veri niteliğindeki bilgilerin farklı bir suç ile ilgili olarak başlatılan bir soruşturma kapsamında kullanılamayacak olmasıdır. Yani veriler, yalnızca hangi suç ile alakalı olarak inceleme yapılmışsa o suçun aydınlatılması için kullanılabilecektir. Ancak, eldeki verilerin farklı bir soruşturma konusu için kullanılması ihtiyacı doğması durumu karşısında, doktrinde önerilen görüş, adeta yeni bir moleküler genetik inceleme yapılacakmış gibi CMK md. 79 uyarınca hâkim kararı alınması suretiyle eldeki verinin kullanılabilmesinin yolunun açılmasıdır. ${ }^{41}$ Kanaatimizce de, bu görüş yerindedir ve özel nitelikli kişisel verilerin korunabilmesini sağlamak adına, farklı bir suç için ihtiyaç duyulması hâlinde yeniden hâkim kararı alınması gerekecektir.

38 Erhan Büken, 'Adli Tipta Genetik Araştırmalar' (2009) 22 İKU (İyi Klinik Uygulamalar) Dergisi 33.

39 Süheyl Donay, Ceza Muhakemesi Kanunu Şerhi (Beta, İstanbul 2009) 135.

40 Yargitay CGK 2017/1-225 E 2018/129 K say1l 27/3/2018 tarihli karar.

41 Centel and Zafer (n 33) 330. Doktrinde ayrıca, DNA analizi yapılmasının esas sebebi olan soruşturma ve kovuş̧urma dışında kalan, ancak yine de bununla bağlantılı olan diğer bir yargılamada da örneklerin kullanılabileceği görüşü bulunmaktadır. Bu yönde bkz. Ünver and Hakeri (n 13) 283. 


\subsection{2. İncelemenin Zorunlu Olması Koşulu}

Belirtildiği üzere, moleküler genetik incelemede amaç; soybağının tespit edilmesi veya elde edilen bir bulgunun şüpheli veya sanığa ya da mağdura ait olup olmadığının belirlenmesidir. CMK md. 78 metninde bu yönteme başvurulabilmesi için "zorunlu olma koşulu" getirildiğinden, moleküler genetik inceleme yönteminin uygulanması zorunlu olmadıkça, yani bir diğer deyişle, başka bir yol ile delil elde etme olanağı söz konusu olduğu takdirde, moleküler genetik inceleme yöntemine başvurulamayacaktır. ${ }^{42}$

$\mathrm{Bu}$ şekildeki bir koşulun varlığı, uygulamanın hem zorunluluk hem de ikincillik özelliği taşıdığııı göstermektedir. ${ }^{43}$ Çünkü delil elde etmek bakımından başka bir olanak bulunuyorsa veya yöntem daha önce kullanılmışsa, artık moleküler genetik incelemeye başvurmak gerekli olmayacaktır. Öngörülen bu koşulun, özel nitelikli kişisel verilerin korunması bakımından bir güvence sağladığı söylenebilecektir. ${ }^{44} \mathrm{Zira}$ kanaatimizce de moleküler genetik inceleme yönteminin yalnızca zorunlu olan hâller ile sınırlı tutulması, kamusal yarar ile bireyin çıkarları arasında kurulması gereken dengenin ihlâl edilmemesi açısından önem arz etmektedir.

Doktrinde belirtildiği üzere, zorunluluk değerlendirmesi yapılırken, moleküler genetik inceleme işlemine başvurulmasının muhakeme sürecini uzatacağının ve yargılama masraflarını artıracağının da nazara alınması gerekmektedir. ${ }^{45}$

Doktrindeki bir görüş tarafından ise, CMK md. 78 açısından aranması gereken hususun "zorunluluk" şartı yerine "ölçülülük" ilkesine uygunluk olması gerektiği savunulmaktadır. Zira bu görüşe göre, zorunluluk şartına riayet edilmesi, moleküler genetik inceleme yöntemine başvurulabilecek olan durumları bir hayli azaltmakta, dolayısıyla da yöntemin uygulanabilirliğini oldukça fazla kısıtlamaktadır. ${ }^{46}$ Ölçülülük ilkesi esas alınarak moleküler genetik inceleme yöntemi uygulandığında ise, kamu yararı ve özel hayatın korunması arasında genel bir değerlendirme yapılması yanında, tedbirin gerekliliği ile istenen amaca ulaşılıp ulaşılamayacağı da dikkate alınacağından, bu usulde de yine bir hukuk devleti açısından olması gerektiği şekilde bir uygulama

42 Uygulamada, zorunluluk koşulunun gerçekleşip gerçekleşmediğine dair kimi tereddütler söz konusu olabilmektedir Bu nedenle, moleküler genetik inceleme yapılması gereken durumlarda yapılmaması, tam askine yapılması zorunlu olmayan hallerde ise yapılması mümkün olabilmektedir. Bu yönde bkz. Batur (n 31 ) 83 .

45 Batur (n 31) 84.

46 Ünver and Hakeri (n 13) 282. 
gerçekleştirilmesinin mümkün kılınacağı belirtilmektedir. ${ }^{47}$ Ölçülülük kavramı, zorunluluk kavramından daha göreceli bir anlam ifade ettiğinden ve ülkemizde çok farklı konularda tartışmalara sebep olabildiğinden, bu kavramın esas alınması durumunda özel nitelikli kişisel verilerin yeterli bir korumaya sahip olmayacağı endişemizden ötürü, moleküler genetik inceleme yöntemine başvurulması bakımından zorunluluk koşulunun muhafaza edilmesi gerektiğini düşünmekteyiz.

Yine bu kapsamda ele alabileceğimiz önemli bir husus da işlenen her suç için moleküler genetik inceleme yöntemine başvurulamayacak olmasıdır. Bilindiği üzere, CMK md. 78 uyarınca soybağının veya elde edilen bulgunun şüpheli veya sanığa ya da mağdura ait olup olmadığının tespiti amaçlarıyla moleküler genetik inceleme yapılabilmektedir. Ancak, CMK md. 75/5 hükmü gereğince, kişi üzerinde iç beden muayenesi yapılabilmesi, kişiden kan veya benzeri biyolojik örnekler ile saç, tükürük, tırnak gibi örnekler alınabilmesi için bu kişinin üst sınırı iki yıldan daha fazla hapis cezasını gerektiren bir suçun faili olması gerekmektedir. Bu nedenle eğer bir kişi, üst sınırı iki yıldan daha az hapis cezasını gerektiren bir suçun faili ise, kendisinden moleküler genetik incelemeye konu yapılacak örnekler alınamayacağından, söz konusu suç açısından moleküler genetik inceleme yapılması yolu da kapanmış olacaktır. Zira, vücuttan örnek alınmasının esas sebebi zaten moleküler genetik inceleme yapılabilmesine olanak sağlamaktadır. ${ }^{48}$ Yargıtay tarafından da bir kararda bu hususa dikkat çekilmiş olduğu görülmektedir. ${ }^{49}$

Zorunluluk değerlendirmesi bakımından son olarak değinmek istediğimiz husus, moleküler genetik inceleme yöntemine başvurulabilmesi için şüphenin kuvvet derecelerinden hangisinin aranacağına ilişkin herhangi bir ibareye yer verilmemiş olmasıdır. ${ }^{50} \mathrm{CMK}$ hükümlerinin geneline baktığımızda, zorunluluk koşuluna riayet etmek esas olduğundan, tarafımızca bu hususta basit başlangıç şüphesi ile yetinilmeyeceği düşünülmektedir. Her ne kadar kanunumuzda bu konuda bir açıklık olmasa da, daha sonra aşağıda ayrıntılı olarak yer vereceğimiz Alman Ceza Muhakemesi Kanunu StPO § 81h düzenlemesinde yer verildiği gibi “somut olgular” bulunması koşulu düşünülebilecektir. Fakat her hâlükârda kanun koyucunun bu husustaki tereddütleri gidermesi ve zorunluluk koşulu ile uyumlu bir anlayışın benimsenmesini sağlaması gerekmektedir.

47 Özbek (n 19) 1094.

48 Şahin and Göktürk (n 37) 88; Mahmutoğlu (n 18$) 3$.

49 Yargitay 23 CD 2015/20329 E 2015/7193 K say1l 25/11/2015 tarihli karar.

50 Mahmutoğlu (n 18) 6-7. 


\subsubsection{Hâkim Kararı Bulunması Zorunluluğu}

Türk ceza muhakemesi hukukuna göre, moleküler genetik inceleme yöntemine başvurulabilmesi için bir ceza soruşturması veya kovuşturmasının mevcudiyeti gerekmektedir. Bunun anlamı, Alman uygulamasında söz konusu olduğu gibi, gelecekte gerçekleşebilecek, yani müstakbel bir ceza muhakemesi için veri analizi yapılmasının önünü kapatmaktadır. Zira CMK böyle bir yönteme olanak tanımamaktadır. ${ }^{51} \mathrm{CMK}$ md. 79 gereği, moleküler genetik inceleme yapılması kararı yalnızca hâkim tarafından verilebilecektir. Bu nedenle, tabiidir ki soruşturma evresinde karar, sulh ceza hâkimliği tarafindan verilecektir.

Moleküler genetik inceleme yapılabilmesi için hâkim kararının varlığının aranması, bu görevin, tarafsızlığ 1 ve bağımsızlığ 1 gerek ulusal mevzuatımız ve gerekse uluslararası etik ilkeler ile kabul edilmiş olan kişilere verilmesi bakımından yerinde bir yaklaşım olmuştur. Fakat doktrindeki bir görüş tarafından, moleküler genetik inceleme yapılması yönündeki kararın, yalnızca hâkim tarafından verilebiliyor olması eleştirilmiş, bu şekildeki usulün, uygulamadaki ihtiyaçlara cevap vermediği gibi, suçla mücadeleyi de aslında engellediği ifade edilmiştir. Üstelik bir kararın, hâkim tarafından veriliyor olması durumunda, söz konusu kararın mutlaka hukuka uygun ve tehlikesiz olacağı anlayışının da gerçek ile örtüşmediği belirtilmiştir. ${ }^{52}$ Kanaatimizce, bir kararın sırf hâkim tarafından veriliyor olmasının, bu kararı mutlaka hukuka uygun hâle getirmeyeceği şeklindeki bu tespit yerinde olmakla birlikte, özel nitelikli kişisel verilerin korunması gerekliliği bakımından, karar verme görev ve yetkisinin münhasıran tarafsızlık ve bağımsızlık ilkeleri uyarınca hareket eden hâkimlere tanınmış olması önemli bir güvence sağlamaktadır. Bu sebeple, beşeri hataların asgari düzeyde kalmasını sağlayarak yasaya ve hukukun üstünlüğüne bağl11ık anlayışı çerçevesinde verilen hâkim kararları üzerine moleküler genetik inceleme yöntemine başvurulması yerinde bir yaklaşım olmaktadır. Zira temel hak ve özgürlüklere yönelik önemli bir müdahale arz eder nitelikteki bu kararların, aynı niteliği taşıyan diğer kararlar açısından söz konusu olduğu gibi hâkimler tarafından verilmesi gerekmektedir.

Beden muayenesi yapılabilmesi için gecikmesinde sakınca olan hâllerde, Cumhuriyet

$51 \quad$ Ibid 8.

52 Bu yönde bkz. Yener Ünver and Hakan Hakeri, Ceza Muhakemesi Hukuku, vol 1 ( $8^{\text {th }}$ Edn, Adalet Yayınevi, Ankara 2013) 393. 
savcısı tarafından bu hususta karar verilebilmesi mümkün k1lınmışıır ${ }^{53}$, çünkü örneklerin bozulup özelliklerini yitirme ya da kaybolma ihtimalleri bulunmaktadır. Ancak bu örnekler laboratuvarda uygun koşullarda muhafaza altına alındıktan sonra, moleküler genetik inceleme yapılıp yapılmayacağına karar verilmesi için herhangi bir aciliyet söz konusu olmadığından, her hâlükarda hâkim kararının alınması beklenecektir.

Daha evvel de ifade ettiğimiz üzere, moleküler genetik incelemeler, beden muayenesi hükümleri uyarınca elde edilen vücut örneklerini konu aldığından, öncelikle CMK 75 ve 76'ncı maddeler gereğince vücuttan örnek alınması için bir hâkim kararı bulunması, daha sonra ise, alınan bu örnekler üzerinde moleküler genetik inceleme yapılabilmesi için de ayrı bir hâkim kararı bulunması gerektiğine dikkat çekilmelidir. Görüldüğg̈ üzere, esasında moleküler genetik inceleme yapılabilmesi için ikinci bir hâkim kararının varlığı aranmakta, çift aşamalı bir karar sürecinin tamamlanması gerekmektedir. ${ }^{54}$

Beden Muayenesi Yönetmeliği md. 23'de belirtildiği üzere, kişinin vücut yüzeyinde bulunan atış artığı gibi biyolojik olmayan örnekler, elbiseleri ve diğer eşyaları üzerinde bulunan örnekler ile vücut yüzeyinden başkasına ait olduğu açıkça belli olan kıl, tüy, lif gibi örneklerin alınması "diğer işlemler" olarak nitelendirilmektedir ve bu kategoriye giren örnekler, olay yeri inceleme uzmanları tarafindan toplanabilmekte, bu konuda hâkim kararı veya Cumhuriyet savcısı emrinin bulunması gerekmemektedir. Niteliği gereği bu örneklerin derhâl muhafaza altına alınması ihtiyacı bulunduğundan bu düzenleme zorunludur ve yerindedir. Ancak kanaatimizce, alınan bu materyaller, eğer moleküler genetik incelemeye konu olabilecek vasıfta ise, örneğin henüz kime ait olduğu belirsiz bir k1l ise, CMK md. 78/2 gereği bulunan ve kime ait olduğu belli olmayan beden parçası özelliğini taşıdığından, bu örnek üzerinde moleküler genetik inceleme yapılmadan evvel yine bu hususa ilişkin bir hâkim kararının varlığı aranacaktır.

Moleküler genetik inceleme yapılabilmesi için hâkim kararının bir zorunluluk olarak aranması, ilgilinin rızasına dayalı olarak bu incelemelerin yapılamayacağının kabul edilmesi anlamına da gelmektedir. Yargitay tarafindan da beden muayenesi ve vücuttan örnek alınması işlemi açısından, mağdurun rıza göstermesi durumunda, hâkim veya Cumhuriyet savcısı kararı bulunmasına gerek olmamasına rağmen (CMK md. 76/2), mağdurdan alınan örnekler ile suça ilişkin olarak elde edilen bulguların

53 Gecikmesinde sakınca olan hallerde Cumhuriyet savcısı tarafından verilen kararın, 24 sat içerisinde hâkim veya mahkeme onayına sunması gerektiğinden, doktrinde ifade edilen bir görüşe göre, zaman tasarrufu yapılabilmesi adına, Cumhuriyet savcısının onay sırasında ayrıca genetik inceleme yapılması yönünde karar talep etmesi de uygun olacaktır. Bu yönde bkz. Ünver and Hakeri (n 13) 282.

Kunter and others, (n 34) 691. 
karşılaş̧ırılması, diğer bir ifadeyle moleküler genetik inceleme işleminin yapılabilmesi için hâkim kararının bulunması gerektiğine dikkat çekilmektedir. Bunun, kanunun amir hükmü olduğuna ve riayet edilmediği takdirde bozma gerekçesi yapılacağına dikkat çekilmektedir. ${ }^{55}$

Şüphesiz ki Yargıtay'ın bu değerlendirmesi son derece yerindedir. Zira moleküler genetik inceleme özel ve hassas bir durum teşkil etmektedir ve açıklandığı üzere CMK'da ayrıca düzenlenmiş ve ilgili yönetmelikte de yer almıştır. Kanunda açıç̧a belirtildiği üzere, veri sahibi kişinin haklarını korumak amacıyla bu işlem hâkim kararına bağlanmıştır. Kanun, emredici şekilde hâkim kararının bulunmasını ararken ve bu kararın özelliklerine ilişkin detaylı düzenlemelere yer verirken, uygulamada ilgilinin rızasının bulunması gerekçe olarak gösterilmek suretiyle moleküler genetik inceleme yapılması, kanuna açıkça aykırılık teşkil edecektir. Moleküler genetik incelemenin konusunu oluşturan örnekler, belirttiğimiz üzere kişisel verilerin sınıflandırılması açısından özel nitelikli kişisel veri kategorisine girmektedir. Bu nedenle, örneklerin alınması ve örnekler üzerinde yapılacak olan işlemler hâkim kararına bağlanmıştır, çünkü bir kimsenin böyle bir inceleme için gerçekten özgür iradesi ile rıza gösterip göstermediği ya da bu rızanın kapsamını tespit etmek her zaman kolay olmayacaktır.

Yargıtay tarafından ayrıca, hâkim kararı bulunması şartı ile olay mahallinden elde edilen bulgular üzerinde de moleküler genetik inceleme yapılabileceği vurgulanmaktadır. Bu konuya ilişkin olarak Yargıtay 6. Ceza Dairesi'nin bir kararında ${ }^{56}$; hırsızlık suçunun işlenmesi ardından olay yerinde bulunan ve delil olması nedeniyle muhafaza altına alınan 2 adet eldiven poşeti üzerinde DNA incelemesi yapılmasına yönelik Cumhuriyet Başsavcılığı'’nın talebinin, ilk derece mahkemesi tarafından, CMK'nın ilgili maddelerinde olay yerinden elde edilen materyaller üzerine DNA incelemesi yapılabilmesi işleminin belirtilmediği, CMK'nın 78. maddesinde hâkim kararı gerektiren inceleme konusu olarak yalnızca 75 ve 76. maddelerde öngörülen işlemlerle elde edilen örneklerin sayılmış olduğu, olay yerinden elde edilen herhangi bir eşya veya materyal (somut olay açısından eldiven poşeti) üzerinde DNA incelemesi yapılmasının CMK'da öngörülmediği gerekçesi ile reddedilmesine ilişkin kararın bozulmasına hükmetmiştir. 
$\mathrm{Bu}$ kararda da Yargıtay yine olması gerektiği şekilde hükme varmıştır. Zira CMK md. 78/2'de, bulunan ve kime ait olduğu belli olmayan beden parçaları üzerinde de moleküler genetik inceleme yapılmasına izin verilmektedir. Görüldüğü üzere, kanunda belirtilen incelemeler yalnızca insan vücudundan alınan örnekler ile sınırlı tutulmamıştır. Olay mahallinde bulunan materyaller üzerinde yapılacak olan inceleme sonuçları, mukayese edilecek bir örnek bulunamasa dahi, suçun çözümlenmesi açısından aşama kaydedilmesine fayda sağlayacaktır. Yukarıda ilgili bölümde belirttiğimiz üzere, bu nitelikteki bir inceleme sonucunda elde edilen bulgunun insana $\mathrm{m} 1$ ait olduğu, eğer bir insana aitse bir kadına mı yoksa bir erkeğe mi ait olduğu, bu kişinin saç rengi ve göz rengi gibi özelliklerinin belirlenmesi ve böylece belki de faile ulaşılması mümkün olabilecektir. Kanun bu konuda herhangi bir kısıtlama getirmezken ve üstelik buna izin verirken, uygulamada bu şekilde kısıtlamalar yaratılması, suçla mücadele açısından etkililik sağlanmasına engel olacak niteliktedir.

Ezcümle, Yargıtay tarafından verilen kararlarda da, CMK'ya uygun şekilde, moleküler genetik incelemelerin yapılabilmesi için mutlaka hâkim kararı bulunması gerektiği vurgulanmaktadır. Her ne kadar kanunun bu konuda açık ve amir hükmü bulunsa dahi, Yargitay tarafindan verilen kararlar vasıtasıyla, uygulamada meydana gelen yanlışlıkların düzeltilmesi ve bu hususta başkaca yanlış uygulamalara taviz verilmemesi son derece önem taşımakta ve yerindelik arz etmektedir.

\subsubsection{Bilirkişinin Objektifliğinin Sağlanması}

Ceza muhakemesi kapsamında, kimi zaman bir suçun, bilirkişi raporu dışındaki deliller ile ispatlanması mümkün olmadığında, bilirkişi incelemesi daha da önem kazanmaktadır. ${ }^{57}$ Kimi zaman ise, özel veya teknik bilgi gerektiren durumlarda hâkimin bilirkişiye başvurması gerekmektedir. İşte moleküler genetik incelemeler de, bilirkişiye başvurulmasını gerektiren durumlardan birini teşkil etmektedir. Gerçekten de Yargıtay kararları da incelendiğinde görüleceği üzere, bilirkişi raporu alınmasını zorunlu kılan durumlar arasında, akıl hastalığı ve parada sahtecilik ile birlikte moleküler genetik incelemeler de sayılmaktadır. Zira belirtilen bu durumlar, kanun koyucu tarafindan, uzmanlık, teknik veya özel bilgi gereksinimi arz ettiği baştan kabul edilen hâller arasinda yer almaktadir. ${ }^{58}$

57 Ali Parlar and Muzaffer Hatipoğlu, 5271 Sayılı Ceza Muhakemesi Kaпипи Yorumu, vol 1 (Ankara 2008) 383.

58 Bu yöndeki kararlar için bkz. Yargıtay CGK 2017/12-709 E 2019/5 K say1l 15/1/2019 tarihli ve Yargıtay CGK 2015/12-1149 E 2016/182 K say1l 5/4/2016 tarihli kararlar. 
CMK md. 79' da da bu doğrultuda, bilirkişiye yönelik açık bir ifadeye yer verilniştir. Buna göre, yalnızca hâkim tarafından verilebilecek olan moleküler genetik inceleme yapılması kararında, bu incelemeyi yapmakla görevlendirilen bilirkişinin de gösterilmesi gerekmektedir. CMK md. 79/2'de kimlerin bilirkişi olarak görevlendirilebileceği ayrıca düzenlenmiştir. ${ }^{59}$

Bununla birlikte, bilirkişi olarak görev yapacak kişilere bazı sorumluluklar da yüklenmiştir. Bilirkişi olarak görevlendirilen kişi, teknik ve teşkilat bakımından uygun tedbirleri alarak yasak moleküler genetik incelemelerin yapılmasını ve yetkisiz üçüncü kişilerin bilgi edinmesini önlemekle yükümlü kılınmıştır (CMK md. 79/2). Bu kişi ayrıca, yalnızca kararda hâkim tarafından belirtilen işlemi yapabilecek, bunun dışında başka herhangi bir inceleme yapamayacaktır. ${ }^{60}$ Bilirkişi tarafından yapılan analizler sonucu elde edilen bulgular ilgili makama gönderilecek, bulgular üzerinden moleküler genetik analizler için izole edilen DNA örnekleri bilirkişi tarafından rapor hazırlandıktan sonra imha edilecek ve bu husus raporda açıkça belirtilecektir (Beden Muayenesi Yönetmeliği md. 14/3).

Bilirkişi olarak görev yapacak kişi açısından bir yükümlülük daha getirilmiş ve Beden Muayenesi Yönetmeliği md. 14/4 düzenlemesi ile, moleküler genetik inceleme yapılırken, özel kalıtsal karakterler hakkındaki açıklamayı içermediği bilinen kromozom bölgesi ile sınırlı kalınmasına özen gösterilmesi gerektiği belirtilmiştir (md. 14/4). Kanaatimizce bu şekildeki düzenleme, bir yanıyla örnekler üzerinde inceleme yapılırken dahi kişisel verilerin mümkün mertebe korunması amacını esas almak suretiyle kanun koyucu tarafından sergilenen bir hassasiyeti ifade etmekte, diğer yanıyla da aslında

59 Maddede belirtildiği üzere: Yapılacak incelemeler için resmen atanan veya bilirkişilikle yükümlü olan ya da soruşturma veya kovuşturmayı yürüten makama mensup olmayan veya bu makamın soruşturma veya kovuşturmayı yürüten dairesinden teşkilât yapısı itibarıyla ve objektif olarak ayrı bir birimine mensup olan görevliler, bilirkişi olarak görevlendirilebilirler. Yapılacak incelemeler için resmen atanan veya bilirkişilikle yükümlü olan ya da soruşturma veya kovuşturmayı yürüten makama mensup olmayan veya bu makamın soruşturma veya kovuşturmayı yürüten dairesinden teşkilât yapısı itibarıyla ve objektif olarak ayrı bir birimine mensup olan görevliler, bilirkişi olarak görevlendirilebilirler. Doktrinde, raporun uzman bir bilirkişi tarafından hazırlanması yeterli görülmeyip aynı zamanda bilirkişinin sahip olduğu teknik olanakların da bu şekilde bir rapor hazırlanmasına elverişli bir düzeyde bulunmasının gerekli olduğu; bu nedenle moleküler genetik incelemeye ilişkin test konusunda bilirkişilik yapacak özel veya resmi merkezler için teknik olanakalar açısından bir standart getirilmesi gerektiği düşünülmektedir. Bu yönde bkz. İsmail Malkoç and Mert Yüksektepe, Ceza Muhakemesi Kanunu I. Cilt, (Malkoç Kitabevi, Ankara 2008), 413. Yine doktrinde, bilirkişi incelemelerinde görev yapan bir tür tekel haline gelmiş Adli Tıp Kurumu (ATK), Emniyet Genel Müdürlüğü Kriminal Polis Laboratuvarları Dairesi (KLP) ve Jandarma Kriminal Daire Laboratuvarları (JKDB)'nın devletin idari yapılanması içinde yer alan müesseseler haline gelmiş olması nedeniyle, "silahların eşitliğii" prensibine uygun biçimde özerk, objektif, bilimsel, tenik araç-yaklaşım ve uzmanlar bakımından ileri düzeyde olan ve TBB inisiyatifinde olacak bir Adli Tıp Akademisi kurulması görüşü de bulunmaktadır. Bu yönde bkz. Hamit Hancı and S Sinan Kocaoğlu, 'Savunma Adli Tıp Akademisi TBB-ATA', Adli Tıp ve Ceza Hukuku (Seçkin Yayıncılık, Ankara 2012) 15. 
moleküler genetik inceleme yönteminin amaca bağl1lık özelliği ile yakından ilişki içinde bulunmaktadır. Zira amaç, örnek sahibinin kalıtsal karakteri hakkında bilgi elde etmek olmadığından, yapılan incelemede bu hususa ilişkin bilgiler içeren alandan uzak durulmaya gayret edilmesi yükümlülüğü getirilmiştir.

İncelemeyi yapacak olan bilirkişinin tarafsızlığını sağlamak adına ${ }^{61}$, moleküler genetik incelemeye konu olacak bulgunun, bilirkişiye verilirken ilgilisinin adı, soyad,, adresi ve doğum tarihinin bildirilmeyeceği de kanunda düzenlenmiştir. Gerçekten de bilirkişinin objektif olması, inceleme bakımından büyük önem taşımaktadır. ${ }^{62}$ Fakat doktrinde, inceleme konusu olacak bulguların bilirkişiye, ilgilisinin isim, adres, doğum tarihi gibi bilgileri olmaksızın teslim edilecek olması nedeniyle, zaten üçüncü kişilerin bunlardan bilgi edinmesinin olanaksızlığına vurgu yapılmak suretiyle, maddenin Alman Ceza Muhakemesi Kanunu'ndan tercüme olması nedeniyle bu yanlışlığı barındırdı $\breve{g}$, maddenin daha anlaşı1ır bir hâle gelebilmesi için yeniden kaleme alınması gerektiği şeklinde bir görüş bulunmaktadır. ${ }^{63}$

Bu noktada dikkat çekilmesi gereken husus şudur ki, CMK md. 79 uyarınca bilirkişiye teslim edilen bulgularda isim, adres, doğum tarihi gibi bunların kime ait olduğunu belirleyici unsurlara yer verilmemesi nedeniyle, söz konusu bulgular henüz kişisel veri niteliğini taşımamaktadır. Bulgular üzerinde yapılacak olan inceleme sonucunda bunlar şüpheli, sanık veya başka bir kişi ile ilişkilendirilirse ve kime ait olduğu bilgisi ortaya çıkarsa, bu takdirde kişisel veri olma niteliğini de kazanmış olacaktır. ${ }^{64}$ Kanun koyucunun bu kadar özenli davranmasının sebebi, söz konusu genetik incelemenin kişilik haklarına ilişkin olmasından kaynaklanmaktadır. ${ }^{65}$ Üstelik, incelemeye konu edilen bulguların özel nitelikli kişisel veri kategorisinde olması, daha özenli bir değerlendirme yapılmasını gerektirmektedir.

\subsubsection{Moleküler Genetik İnceleme Sonuçlarının Gizliliği}

Beden Muayenesi Yönetmeliği md. 14'te moleküler genetik inceleme sonuçlarının gizliliği ayrı bir düzenleme olarak yer almaktadır. Düzenleme kapsamında, örnekler üzerinde yapılan inceleme sonuçlarının kişisel veri niteliği taşıdığı kabul edilmiş olup

61 Osman Yaşar, Yeni İçtihatlarla Uygulamalı ve Yorumlu Ceza Muhakemesi Kanunu, vol 1 (Seçkin Yayınları, Ankara 2011), 1031.

62 Ünver and Hakeri (n 13) 283.

63 Donay (n 40) 136.

64 Ünver and Hakeri (n 13) 283.

65 Soyaslan (n 36) 275. 
bunların farklı amaçlar ile kullanılması, yahut dosya içeriğini öğrenme yetkisine sahip bulunan kişiler tarafından bir başkasına verilmesi yasaklanmıştır (md. 14/1). Yasaklara uyulmaması durumunda, TCK hükümleri uyarınca çeşitli suçlar oluşacaktır ve sorumluluk açısından bu yönde bir değerlendirme yapılması gerekecektir. Somut olayın özelliklerine göre, TCK md. 135 (kişisel verilerin kaydedilmesi), md. 136 (verileri hukuka aykırı olarak verme veya ele geçirme), md. 137 (nitelikli hâller), md. 138 (verileri yok etmeme), md. 257 (görevi kötüye kullanma) veya md. 285 (gizliliğin ihlâli) hükümlerinde yer alan suçların işlenmiş olması nedeniyle ceza sorumluluğu doğabilecektir.

Görüldüğü üzere, moleküler genetik inceleme sonuçlarının gizliliğinin sağlanması bakımından gerek bilirkişilere gerekse dosya ile ilgili inceleme yetkisi bulunan diğer kişilere bir takım sorumluluklar yüklenmiştir. Zira defaatle belirttiğimiz üzere, moleküler genetik incelemenin sonucunda ortaya çıkacak olan veriler, kişinin sağlığı, 1rk1 ve benzeri diğer hususlara ilişkin oldukça hassas ve en üst nitelikli korumaya layık bilgiler içermektedir. ${ }^{66}$ Ancak şuna da dikkat çekmek gerekir ki, inceleme yapan bilirkişi dahi verilerin sahibini bilmezken, kovuşturma evresine geçildiğinde, alenilik ilkesi gereğince, bu bilgiler artık öğrenilebilir hâle dönüşecektir. ${ }^{67} \mathrm{Bu}$ nedenle, en azından dosya ile ilgili görev ve yetkisi olmayan üçüncü kişilerin dosya kapsamında yer alan tüm bilgilere kolayca erişiminin engellenmesi yolunda bir çalışma yapılması gerekmektedir.

\subsection{6. Örneklerin İmha Edilmesi Zorunluluğu}

CMK md. 80/2 düzenlemesinde, bilgilerin, kovuşturmaya yer olmadığı kararına itiraz süresinin dolması, itirazın reddi, beraat veya ceza verilmesine yer olmadığı kararı verilip kesinleşmesi hâllerinde Cumhuriyet savcısının huzurunda derhâl yok edileceği ve bu hususun dosyasında muhafaza edilmek üzere tutanağa geçirileceği düzenlenmiştir. Beden Muayenesi Yönetmeliği md. 14/2'de de aynı düzenleme tekrarlanmıştır. Ancak bu düzenlemelerde kullanılan "bilgiler" ifadesi ile neyin kastedildiği yeterince açıklık taşımamaktadır.

Doktrinde yer alan ve bizim de iştirak ettiğimiz bir görüşe göre, kanun koyucu tarafindan burada kastedilen husus, CMK md. 80/1'de olduğu gibi CMK md. 75, 76 ve 78 uyarınca elde edilen bilgiler olmaktadır. Bu nedenle de bilgilerin yok edilmesi zorunluluğu sadece moleküler genetik inceleme sonucu elde edilen bilgileri değil, aynı

66 Sedat Erdem Aydın, AİHM İçtihatları Bağlamında Kişisel Verilerin Kaydedilmesi Suçu (On İki Levha Yayınc1lık, İstanbul 2015) 103.

67 Soyaslan (n 36) 275. 
zamanda sanık, şüpheli ve diğer kişilerin beden muayenesi yoluyla elde edilen bilgileri de kapsamaktadır. ${ }^{68}$ Doktrindeki başka bir görüşe göre ise bu hüküm, üzerinde inceleme yapılan materyalin imhasını değil, yalnızca inceleme yapılması suretiyle elde edilen sonuçların imhasını düzenlemektedir ve bir kimse hakkında ortaya çıkan yeni deliller sonucu yeniden soruşturma açılması veya yargılamanın yenilenmesi ihtimalleri göz ard1 edilmiş olduğundan, esasında söz konusu hüküm hatalı bir şekilde düzenlenmiştir. ${ }^{69}$

Doktrinde yer alan bu görüşlerden ikincisini benimsemek, hem kişisel verilerin korunması hususunda ihlâl ve suistimalleri beraberinde getirecektir hem de ülkemizde ulusal DNA veri bankası bulunmaması nedeniyle, üzerinde inceleme yapılan materyalin imha edilmemesi durumunda, kanuna aykırı bir şekilde muhafazası anlamına gelecektir ve bunların kabul edilmesi asla mümkün değildir. Bu nedenle, yeterince açık olmayan ve gerekçesinde de bu hususa değinilmeyen CMK md. 80/2 ifadesinin değiştirilmesi, ancak o zamana dek "bilgiler" ifadesinin CMK md. 80/1'de belirtilen tüm hususlar1 kapsayacak şekilde yorumlanması gerekmektedir.

CMK md. 80/2'de, imha zorunluluğunun öngörüldüğü hâller, kovuşturmaya yer olmadığ kararına itiraz süresinin dolması, itirazın reddi, beraat veya ceza verilmesine yer olmadığı kararı verilip kesinleşmesi olarak belirlenmiştir. Bu hüküm, 2005-5353 sayılı kanun ile değiştirilmiştir. Değişiklik öncesinde metinde, bilgilerin kovuşturmaya yer olmadığı kararına itiraz süresinin dolması, itirazın reddi veya hükmün kesinleşmesi hâllerinde en geç on gün içinde Cumhuriyet savcısının huzurunda yok edileceği yazmakta idi. Bu nedenle, 5353 sayılı kanun ile olumlu yönde bir değişiklik yapıldığ görülmektedir. Değişiklik öncesinde kesinleşen hüküm çeşidi açısından bir ayrım yapılmamışken, değişiklik ile her türlü hükmün değil, beraat veya ceza verilmesine yer olmadığına ilişkin hüküm verildiği takdirde bilgilerin yok edileceği belirtilmiştir. Üstelik değişiklik öncesinde yok etme işlemi için sebebi belirsiz bir şekilde en geç on günlük süre tanınması yerine, şu an söz konusu olduğu hâliyle, imha işleminin derhâl gerçekleştirilmesi, kişisel verilerin korunmasına ilişkin hassasiyet bakımından, kanaatimizce daha isabetli olmuştur.

Kanun koyucu tarafından, bilgilerin yok edilmesi işleminin yapılmasının emredildiği hâller, sayım yöntemi ile gösterilmiş olduğundan, bunlar dışında kalan kararların varlığı durumunda bu bilgilerin yok edilmesi gerekmediği sonucu ortaya çıkmaktadır. $\mathrm{Bu}$ 
durum nedeniyle doktrinde, özellikle veri sahibi kişi hakkında mahkûmiyet kararı verilmesi hâlinde bilgilerin muhafazasının mümkün kılındığg düşünülmektedir. ${ }^{70}$ Fakat daha evvel de ifade ettiğimiz üzere, ulusal DNA veri bankamız mevcut olmadığından, hükümlü kişilere ait verilerin muhafazası da hukuka aykırılık teşkil edecektir.

Verilerin imha edilmesi açısından kullanılacak olan yöntem, Beden Muayenesi Yönetmeliği md. 16' da "Cumhuriyet savcısının uygun göreceği usuller" denilerek ifade edilmiştir ve bunun dışında herhangi bir açıklık getirilmemiştir. ${ }^{71}$ İmha prosedürüne ilişkin olarak mevzuatta özel bir düzenleme bulunmamakla birlikte, genel olarak tıbbi atıkların imhasına ilişkin hükümler içeren Tıbbi Atıkların Kontrolü Yönetmeliği’nde ${ }^{72}$ düzenlenen esasların uygulanması olanaklı görülmektedir. ${ }^{73} \mathrm{Bu}$ açıdan, anılan Yönetmelik'te md. 20'de düzenlenen, tıbbi atıkların yakılması usulünün izlenmesi, imha bakımından en uygun yöntem olacaktır.

Verilerin imha edilmemesi durumunda ise, TCK md. 138/2 uyarnnca verileri yok etmeme suçunun nitelikli hâli işlenmiş olacaktır. Bilindiği üzere, TCMK 138/1'de verileri yok etmeme suçu düzenlenmiş, kanunların belirlediği süreler geçmiş olmasına karşın, verileri sistem içinde yok etmekle yükümlü olan kişilerin, bu görevlerini yerine getirmemeleri durumunda hapis cezasına mahkûm edilecekleri belirtilmiştir. TCK md. 138/2'de ise açıkça ceza muhakemesi hukukuna atıfta bulunulmuş ve 2014-6526 say1lı Kanun ile eklenen bu fikra uyarınca, suçun konusunun CMK hükümlerine göre ortadan kaldırılması veya yok edilmesi gereken verilerden olması hâlinde, faile verilecek olan cezanın bir kat artırılacağı kabul edilmiştir. Özel nitelikli kişisel veri olma vasfi taşıyan moleküler genetik inceleme sonuçlarının ve hücre örneklerinin imha edilmemesi durumunun, söz konusu suç bakımından nitelikli bir hâl olarak düzenlenmesi ve faile verilecek olan cezanın ağıllaştırılacağının kabul edilmesi yerinde bir yaklaşım olmaktadır.

Son olarak şunu da belirtmek isteriz ki, moleküler genetik inceleme yapılmasına ihtiyaç bulunmadığı veya bu yönde hâkim kararı verilmediği takdirde, beden muayenesi sonucu elde edilen bulgular da, eğer istenilen amaca ulaşılmış ise, aynı şekilde imha prosedürüne tabi tutulacaktır.

70 Yaşar (n 62) 1031.

71 Beden Muayenesi Yönetmeliği md. 14/2: Kovuşturmaya yer olmadığı kararına itiraz süresinin dolması, itirazın reddi, beraat veya ceza verilmesine yer olmadığı kararı verilip kesinleşmesi hâllerinde bu Yönetmeliğin 15 inci maddesi hükümleri uyarınca elde edilen veriler, Cumhuriyet savcısının huzurunda ve uygun göreceği usullerle derhâl yok edilir ve bu husus tutanağa geçirilir.

72 Resmi Gazete Tarihi 22/07/2005, Sayıs 25883

73 Hakan Kızılarslan, Vücudun Muayenesi \& Örnek Alma (Kızılarslan Serisi I, Ankara 2007) 145. 


\section{Türkiye'de DNA Veri Bankası Kurulmasına İlişkin Değerlendirmeler}

Özgürlük ve güvenlik dengesinin kurulmasına dair problemlerden biri de DNA veri bankalarının varlı̆̆ına ilişkin olmaktadır. Bu konuda sergilenen iki temel yaklaşımdan biri, biyoteknolojik ilerlemelerden faydalanmak suretiyle kriminolojik olayların çözümünü kolaylaştırmak ve hızlandırmaktan yana olurken, diğeri temel hak ve özgürlüklere ilişkin müdahalelerin söz konusu olacağı endişesi ile çeşitli çekinceler ileri sürmektedir. Daha sonra ayrıntılı olarak inceleyeceğimiz üzere, mukayeseli hukukta ABD, Birleşik Krallık ve Almanya gibi gelişmiş ülkeler kendi ulusal DNA veri bankalarına sahip iken, ülkemiz açısından bu konu yalnızca bir kanun tasarısından ibaret olarak kalmıştır.

Türkiye'de de ulusal bir DNA veri bankası kurulması amaciyla 2007 yılında Adalet Bakanlığı tarafından "DNA Verileri ve Milli DNA Veri Bankası Kanunu Tasarısı" hazırlanmıştır. ${ }^{74}$ Ancak geçen uzun yıllar boyunca bu konuda herhangi bir çalışma yapılmadığı ve konu TBMM gündemine alınmadığı için tasarı artık kadük hâle gelmiştir. Yine de konuya ilişkin olarak hazırlanmış bir metin olmasından ötürü ve ileride ülkemizde ulusal DNA veri bankası kurulması konusu yeniden ele alınacak olursa önem kazanacağından, söz konusu kadük tasarının kısaca değerlendirilmesi gerekmektedir. Zira gelecekte yeni bir yasal düzenleme hazırlanırken, kadük tasarıya yöneltilen eleştirilerin dikkate alınması da fayda sağlayacaktır.

Söz konusu tasarının amacı, kimlik tespiti veya adli amaçla DNA örneklerinin alınmas1, analiz yapılması, verilerin saklanması, verilerden yararlanılması ve veri bankasının kuruluş ve görevlerini düzenlemek olarak belirtilmiştir (md. 1). Ancak özellikle dikkat çeken birkaç madde, veri bankası kurulması konusundaki çekinceleri artırır nitelik taşımaktadır. Zira DNA analizi yapılabilecek biyolojik örnekler sayılırken, görevleri sebebiyle hayatî risk taşıyan kişilerden ve gönüllü kişilerden alınan örnekler de kapsama dâhil edilmiştir (md. 5). Tüm kolluk görevlileri, itfaiyeciler, maden ocaklarında çalışanlar ve diğer bazı tehlikeli faaliyetlerde bulunan kişilerin sayısının çokluğu düşünüldüğünde, "görevi sebebiyle risk altında bulunan kişi” kavramı çok geniş ve belirsiz bir hâl almaktadır. "Gönüllü olma" hususunun ne şekilde belirleneceğinin ise ayrıca ve açıkça düzenlenmesi gerekmektedir. Bu muğlak ifadeler, kanaatimizce göze çarpan ilk eksiklikler olmaktadır.

74 Tasarının tam metni için bkz. <http://www.ttb.org.tr/haberarsiv_goster.php?Guid=665acfee-9232-11e7b66d-1540034f819c > accessed 21 July 2019. 
Dikkate değer bir başka önemli husus, DNA analizi yapmaya yetkili olarak gösterilen kurumlara ilişkin olmaktadır. Bunlar, Adli Tıp Kurumu, Jandarma Genel Komutanlığ Kriminal Daire Başkanlığı ve Emniyet Genel Müdürlüğü Kriminal Polis Laboratuvarları Dairesi Başkanlığı olarak belirtilmiştir (md. 6). Fakat takdir edileceği üzere, yürütmeye bağlı olan bu kuruluşlar tarafindan gerçekleştirilecek işlemler ile objektif bir işleyişin ne derecede sağlanabileceği hususunda önemli soru işaretleri oluşmaktadır. Bu nedenle, yeni bir düzenlemede tarafsızlık konusunda güven veren, en azından sivil denetim imkânını tanıyan bir yapının oluşturulması önem taşımaktadır.

Bir başka husus ise, tasarıda DNA profillerinin yurtdışına aktarılmasına ilişkin düzenleme bulunması (md. 11) konusundaki tereddütlerdir. Yabancı ülkelere veri aktarımı konusunda özellikle zorunluluk ve mütekabiliyet ilkelerine sıkı surette bağlılık ve hassas bir değerlendirme yapılması büyük önem taşımaktadır.

Elbette ki, diğer ülkelerde olduğu gibi, bizim ülkemizde de kriminolojik vakaların daha hızlı ve kolay bir şekilde çözümlenebilmesi için ulusal DNA veri bankası oluşturulması fayda sağlayacaktır. Ancak konu son derece hassas olduğundan, herhangi bir suistimalin söz konusu olamayacağı bir biçimde düzenleme yapılması gerekmektedir. Hazırlanacak yasal bir düzenlemede, verilerin elde edilmesi ve saklanmasına dair yasaklamalar açık olarak belirtilmekle birlikte, ne tür verilerin kimler tarafindan ve ne kadar süre ile saklanabileceğine dair ayrıntılı ifadelere yer verilmesi gerekmektedir. ${ }^{75}$ AİHM de, verdiği kararlarda gördüğümüz üzere, ceza yargılaması sisteminde, modern bilimsel tekniklerin kullanımına ne pahasına olursa olsun, yani bu tekniklerin kullanımının sağlayacağı faydalar ve özel yaşamın korunmasına ilişkin hususlar arasında denge kurulmaksızın, izin verilmesi hâlinde AİHS md. 8'in sağladığı güvencenin etkisinin düşmüş olacağına işaret etmektedir. Bu nedenle, bizim de temel hak ve özgürlükler bakımından herhangi bir ihlâle mahal vermeyecek ve AİHM tarafindan belirtilen hususlara uygun şekilde bir yapı oluşturmamız gerekmektedir.

Ülkemizde bir DNA veri bankası kurulması, doktrinde yoğun şekilde desteklenmektedir. ${ }^{76}$ Özellikle suç faillerinin tespiti açısından kullanılan DNA analizinin

75 Yücel Arısoy, Çiğdem Eresen and Veli Özer Özbek, 'Yeni Yasal Düzenlemeler ve Moleküler Genetik İncelemeler' (2008) 28 (2) Türkiye Klinikleri Journal of Medical Sciences 181.

76 Veli Özer Özbek, 'DNA Verileri ve Türkiye Milli DNA Veri Bankası Kanunu Tasarısı Hakkındaki Görüşlerimiz' (2007) 1 Ceza Hukuku Dergisi 65; Ünver and Hakeri (n 13) 283; Faruk Turhan, Ceza Muhakemesi Hukuku (Asil Yayın Dağıtım, Ankara 2006) 301; Aygörmez Uğurlubay (n 12) 71; Rahime Erbaş, 'The Tension between Genome Privacy and Criminal Justice in the Wake of DNA Databases' (2017) 5 (2) Ceza Hukuku ve Kriminoloji Dergisi (Journal of Penal Law and Criminology) 167. 
mukayeseye dayanan ve kısa sürede sonuç veren önemli bir işlem olması nedeniyle, daha önce bir şekilde ceza muhakemesi işlemlerine maruz kalmış olan kişilerden vücut materyali alınarak bunların DNA analizi sonuçlarının bilgisayar ortamında saklanması, yani bir DNA veri bankası oluşturulması gerekli görülmektedir. Hatta Türkiye’nin DNA profillerini veri bankasına kaydetmiyor olmas1, hem ulusal hem de uluslararası suçların aydınlatılması konusunda çağın gerisinde kalmasına sebep olarak gösterilmekte ve mevcut analiz sonuçlarını imha ederek israf yaptığı da savunulmaktadır. ${ }^{77}$

Diğer yandan, DNA veri bankası kurulması durumunda, elde tutulan verilerin kötüye kullanılacağı, herkesin fişleneceği endişesi, DNA içeriğinin kişilik haklarından ayrı tutulamayacağı ve bu yüzden de bilgilerin DNA veri bankasında toplanmasının bile başlı başına kişilik haklarına yönelik bir saldırı olacağı da düşünülmektedir. ${ }^{78}$

Kanatimizce de DNA veri bankası kurulması gerektiğini savunanlar tarafından belirtilen gerekçeler yerindedir ve ülkemizde bir ulusal DNA veri bankası kurulması ihtiyacı bulunmaktadır. Ancak evvela şunu belirtmek gerekir ki, DNA örneği ve DNA profili birbirlerinden farklı anlamlara gelmektedir. DNA örneği, kişiden alınan ve üzerinde inceleme yapılan kan, tükürük, saç gibi unsurlardan elde edilecek orijinal hücreleri ifade ederken, DNA profili bu örneklerin incelenmesi sonucunda oluşturulan ve dijital ortama aktarılan bilgi anlamına gelmektedir. ${ }^{79}$ Daha basit bir şekilde ifade etmemiz gerekirse, suç şüphelisinden alınan bir damla kan, DNA örneği teşkil etmektedir, ancak bu kişinin A (rh) + kan grubuna sahip olduğunun belirlenmesi DNA profili oluşturulması anlamına gelmektedir. Görüldüğü gibi, örneklerin muhafazası başka ne tür incelemelerin yapılabileceğinin belirli olmaması nedeniyle temel hakların ihlâli bakımından çok daha riskli, farklı amaçlarla kötüye kullanıma ve suistimallere açık bir durum meydana getirmektedir. Bu nedenle, daha sonra ayrıntılı olarak inceleyeceğimiz üzere, AİHM tarafından da kabul görmemektedir. Buna mukabil, inceleme sonucu

77 Aygörmez Uğurlubay (n 12) 71.

78 İmdat Elmas and Gökhan Ersoy, 'Adli Olgulardan Biyolojik Örnek Alınması ve Moleküler Genetik İncelemelerde Yasal Boyut' (2009) 22 Klinik Gelişim Dergisi Adli Tıp Özel Sayısı 113.

79 Azeem Suterwalla, 'Collection and Retention of Personal Data' Human Rights in the Investigation and Prosecution of Crime (Oxford University Press, Oxford 2009) 185. Bu fark, doktrinde şöyle açıklanmaktadır: "Adli DNA bankası ve DNA veri tabanı kavramlarının iyi bilinmemesi ve bu iki farkl kavramın çoğu zaman yanlış olarak birbirinin yerine kullanılması kayglların nedenlerinden biri olarak değerlendirilebilir. DNA bankaları, DNA profili çıkarılmak üzere alınmış doku, hücre veya izole edilmiş DNA'nın daha sonra analizini gerçekleştirmek amacı ile uzun süre depolandığı merkezlerdir. Adli DNA bankasında suçluya ait biyolojik örnekler, suçlunun ayrıntılı kimlik bilgileri, olayla ilgili örnekler, analiz bilgileri ve sonuçları saklanmaktadır. Buna karşın DNA veri tabanı, suç ve suçlu bağlantısının araştırllması için gereken minimal bilgiyi içermekte, tüm işlemler kodlarla yürütülmekte, kişiye ait kimlik bilgileri tutulmamaktadır.” Bkz. Ayşim Tuğ, 'Adli DNA Bankalarına Toplumun Yaklaşımı’ (2007) 21 (2) Adli Tıp Dergisi, 7. 
ortaya çıkan veriler ile oluşturulan profillerin saklanması bakımından aynı tehlike doğmamaktadır. Zira bu profiller üzerinden farklı sonuçları ortaya koyacak yeni incelemeler yapılması mümkün olmayıp yalnızca diğer profiller ile karşılaştırma yapılması imkânı sunulmaktadır. Oluşturulacak DNA veri bankası bu nedenle, biyolojik örneklerin saklandığı bir bankayı değil, bir dizi rakamdan oluşan DNA profillerinin dijital olarak saklandığı ve birbiri ile karşılaştırılabildiği bir bilgisayar programını, bir veri tabanını ifade etmektedir. ${ }^{80}$

DNA veri bankası oluşturulması, özellikle suçların çözülmesi açısından büyük bir kolaylık imkânı sağlamakla birlikte, hak ve özgürlükler temelinde ihlâllere yol açmayacak bir yapılanmayı gerektirmektedir. Bu bakımdan, DNA veri bankasında kimlerin verilerinin saklanması gerektiği, yalnızca suça karışan kişilerin verileri saklanacaksa hangi suçlar açısından bu uygulamanın geçerli olacağı ve verilerin ne zamana kadar saklanacağı gibi sorulara yanıt aranmaktadır. ${ }^{81}$

İfade edildiği üzere, mevcut yasal düzenlemelerimiz çerçevesinde bir DNA veri bankası kurulması imkânı bulunmamaktadır. ${ }^{82}$ Yargıtay tarafından da DNA örneklerinin saklanmasının herhangi bir yasal dayanağı olmadığı, adli soruşturma sebebiyle alınan örnekler üzerinde yapılan inceleme sonuçlarının bir sisteme kaydedileceğine dair mevzuatımızda bir hüküm bulunmadığına dikkat çekilmektedir. ${ }^{83}$ Anılan kararda yer verilen tespitler son derece yerindedir, ancak ne yazık ki muhalif üyenin görüşleri olarak yer almaktadir.

80 Semizoğlu (n 22) 325.

81 Büken (n 39) 35.

82 "Her ne kadar Ceza Muhakemesinde Beden Muayenesi, Genetik Incelemeler ve Fizik Kimliğin Tespiti Hakkında Yönetmeliğin 17. maddesine göre, mahkûmiyet kararl verilmesi halinde bu Yönetmeliğin 15. maddesinin birinci ve ikinci fikraları uyarınca elde edilen veriler (fotoğrafi, iris görüntüsü, beden ölçüleri, diș izi, parmak ve avuç içi izi, bedeninde yer almıș olup teșhisini kolaylaștıracak eșkal bilgileri, kulak, dudak gibi organların biraktığl kimlik tespitine yarayabilecek vücut izleri ile sesi ve görüntüleri) kolluk tarafindan, üçüncü fikrasında belirtilen diş izleri ise bu işlemi yapan sağllk kuruluşu tarafindan arşivleneceğ $i$ belirtilmiş ise de bu bilgilerin fizik kimliğinin tespiti ile ilgili olup, DNA verilerini içermediği açıktır. Kaldı ki, fizik kimliğin tespitine dair verilerin arşivlenebilmesinin ön koşulu da kişi hakkında mahkûmiyet kararı verilmesidir. Yönetmeliğin bu hükmü, DNA verilerinin arşivlenmesine kesinlikle izin veren bir hüküm değildir ve Türkiye Cumhuriyeti Anayasası'nın 20/3 ncü maddesi hükmü nazara alındığında bu şsekilde yorumlanması da mümkün değildir." Bkz. Yargitay 17 CD 2016/10020 E 2016/11226 K say1lı 1/11/2016 tarihli karar.

83 Kararda, AïHM' in "S and Marper v Birleşik Krallık" kararına gerekse TC Anayasa Mahkemesi'nin 02/11/2015 tarihli, 2015/32 E ve 2015/102 K sayılı kararına atıf yapılarak, sanığın daha evvel işlediği başkaca bir suç nedeniyle hukuka uygun olarak alııı alınmadığı dahi tespit edilmemiş vücut örnekleri üzerinde yapılan çalışma sonucu elde edilen genotip özelliklerin hukuka aykırı olarak bir sisteme kaydedildiği ve yargılama konusu olayda olay mahallinde bulunan çorap üzerinden alınan epitel hücreler üzerinde genotip incelemesi yapılarak sisteme yüklenen sonuçlarla karşılaştırllıp sanığa ait olduğunun tespit edilmesinin CMK md. 217/2'de öngörülen "Yüklenen suç, hukuka uygun bir şekilde elde edilmiş her türlü delille ispat edilebilir" hükmüne açıkça aykırı olduğu sabit görülmüş ve bu gerekçelerle ilk derece mahkemesi kararının bozularak beraat hükmü verilmesi gerektiği ifade edilmiştir. Bkz. Yargıtay 17 CD 2016/10020 E 2016/11226 K sayılı 1/11/2016 tarihli karar. 
Neticede vardığımız sonuç, ülkemizde DNA veri bankası kurulmasının bir ihtiyaç olduğu, ancak bunun için öncelikle yasal bir dayanak hazırlanması gerektiğidir. Bu uğurda yapılması gereken hususlardan biri ve belki de en önemlisi, mukayeseli hukuk örneklerini incelemek suretiyle özel nitelikli kişisel verilerin korunması bakımından örnek teşkil edebilecek uygulamaları benimserken, temel hak ve özgürlükler açısından ihlâller yaşanmasına müsait olması bakımından eleştirilen yönlerden kaçınmak olacaktır. Ulusal DNA veri bankasına uzun yıllardır sahip olan farklı ülkelerin uygulamaları, mukayeseli hukukta moleküler genetik inceleme yönteminin ele alınışı çerçevesinde, aşağıda ayrıntılı olarak incelenecek ve ardından, sonuç bölümünde, ülkemiz açısından tavsiye niteliğindeki görüşlerimize yer verilecektir.

\section{Mukayeseli Hukukta Moleküler Genetik İncelemeler}

\subsection{Almanya}

\subsubsection{Genel Olarak}

Moleküler genetik inceleme yöntemi, Alman ceza muhakemesi hukuku bakımından da başvurulan bir yöntem teşkil etmektedir. Bu kapsamda, Alman Ceza Muhakemesi Kanunu StPO § 81e'de moleküler genetik incelemelerin düzenlendiği görülmektedir. ${ }^{84}$ Üstelik bu madde, moleküler genetik inceleme yöntemine yasal bir dayanak kazandıran ilk hukuki düzenleme olarak bilinmektedir. ${ }^{85}$ StPO § 81e ile birlikte, StPO § 81g'de DNA ile kimlik tespiti ve StPO $\S 81$ h'de ise toplu DNA incelemesi yap1lması düzenlenmiştir.

Öncelikle belirtmek isteriz ki, Alman ceza muhakemesi hukukunun, moleküler genetik incelemeler konusunda Türk ceza muhakemesi hukukundan temel farkı, bu tür incelemelerin mevcut bir ceza muhakemesi kapsamında yapılması ve gelecekte gerçekleşebilecek olan bir ceza muhakemesinde kullanılmak üzere yapılması şeklindeki

84 StPO § 81e Moleküler Genetik İncelemeler

(1) Soy bağının araştırılması veya ele geçirilen suç izi bulguların şüpheli veya mağdura ait olup olmadığının belirlenmesi için gerekli ise, 81a madde 1'inci fikrası uyarınca elde edilen bulgular üzerinde moleküler genetik incelemelerde yapılabilir; bu esnada kişinin cinsiyeti de belirlenebilir. Birinci cümlede sözü edilen incelemeler, aynı tespitlerin yapılabilmesi amacı ile, $81 \mathrm{c}$ madde uyarınca uygulanan tedbirler sirasında elde edilen bulgular üzerinde de yapılabilir. Birinci cümlede tanımlananların dışında kalan olgulara ilişskin tespitler yapılamaz; bu amaçlara yönelik olarak yapılan incelemeler hukuken kabul edilmemiştir. (2) Birinci fikra uyarınca yapılmasına hukuken izin verilen incelemeler, bulunan, muhafaza altına alınan veya elkonulan suç izi bulguları üzerinde de yapılabilir. Birinci fikranın üçüncü cümlesi ve 81a madde 3'üncü fikrasının birinci yarı cümlesi uygulanır. Tercüme için bkz. Feridun Yenisey and Salih Oktar, Alman Ceza Muhakemesi Kanunu Strafprozeßordnung (StPO) Almanca Metin-Türkçe Çeviri ( $2^{\text {nd }}$ Edn, Beta, İstanbul 2015) 63-64.

Aygörmez Uğurlubay (n 12) 34. 
ikili bir ayrıma tabi tutulması olmaktadır. Genel itibarıyla ise, CMK'nın ilgili madde gerekçelerinde de belirtildiği üzere ${ }^{86}$, bizdeki mevcut bir ceza muhakemesi kapsamında yapılan incelemelere ilişkin düzenlemeler, StPO'ya paralel bir biçimde yapılmıştır. $\mathrm{Bu}$ nedenle, Türk hukuku açısından üzerinde durulan hususları tekrarlamak yerine, bu bölümde iki ülke arasındaki farkları ortaya koyacak hususlara değinilmekle yetinilecektir.

İlk olarak, CMK md. 78'in karşılığı olan StPO § 81e'de, moleküler genetik incelemenin amacı bakımından bir farklılığa yer verildiği dikkat çekmektedir. Zira StPO uyarınca, moleküler genetik inceleme yönteminin uygulanma amaçları arasında cinsiyet tespiti yapılabilmesi de sayılmaktadır. Doktrinimizde bu düzenleme, Türk hukuku açısından örnek gösterilmekte ve aynı amacı CMK'ya da eklememiz durumunda, cinsiyetin belli olduğu bazı durumlarda tüm DNA profillerini tarama ihtiyacı hissetmeksizin zamandan tasarruf edilebileceğine dikkat çekilmektedir. ${ }^{87}$ Alman doktrininde ise, StPO § 81e’de amaç bakımından değişiklik yapılmak suretiyle, moleküler genetik inceleme yöntemi sayesinde failin dışarıdan tanınabilirliğini sağlayacak yönde, saç, göz, ten rengi belirlemek gibi, incelemeler yapılabilmesine de olanak yaratılması gerektiği düşünülmektedir. ${ }^{88}$

İki ülkenin yasal düzenlemeleri arasındaki bir diğer önemli fark, moleküler genetik inceleme yönteminin rızaya dayalı olarak gerçekleştirilebilmesi konusunda ortaya çıkmaktadır. ${ }^{89}$ Esasında, Alman ceza muhakemesi hukukunda da moleküler genetik incelemeye karar verme yetkisi yalnızca hâkime tanınmıştır, ancak bizdeki düzenlemeden farklı olarak, Alman uygulamasında ilgilinin yazılı rızasına dayanılarak savcılık tarafından da işlemin gerçekleştirilmesine karar verilebilmektedir ve bunun için aranan tek koşul, ilgilinin bu konudaki rızasının yeterince aydınlatılmış hâldeyken verilmiş olmasıdır. Ayrıca gecikmesinde sakınca bulunan hâllerde, doğrudan savcı tarafından karar verilmesi de mümkün kılınmıştır. ${ }^{90}$

Görülmektedir ki, büyük paralellik arz eden Türk ve Alman ceza muhakemesi hukuku düzenlemeleri bu noktada da ayrılmaktadır. Zira CMK'da moleküler genetik inceleme yönteminin uygulanmasına ilişkin kararın yalnızca hâkim tarafından

86 <www.ceza-bb.adalet.gov.tr/mevzuat/cmkmaddegerekce.doc> accessed 27 July 2019.

87 Aygörmez Uğurlubay (n 12) 60.

88 Zöller and Thörnich (n 17) 334.

89 Aygörmez Uğurlubay (n 12) 62.

90 Ünver and Hakeri (n 53) 389-390; Zöller and Thörnich (n 17) 334. 
verilebileceği düzenlenmiş, gecikmesinde sakınca bulunan hâller bakımından herhangi bir istisna getirilmemiş ${ }^{11}$ ve ilgilinin rızasının bulunmasına dair farklı bir husus belirtilmemiştir. Her ne kadar StPO § 81 düzenlemesinde rizaya dayalı olarak moleküler genetik inceleme işleminin yapılabileceği belirtilmişse olsa da, bu rızanın ne şekilde verileceği çok ayrıntılı bir biçimde kanunda düzenlenmiştir. Böylece her durumda, ilgilinin rızasının varlığına dayanılarak genetik inceleme işleminin kolaylıkla gerçekleştirilmesinin önü de kapatılmıştır.

Alman ceza muhakemesi hukukunda, ihtiyaç hâlinde toplu DNA incelemesi yapılabilmesi de ülkemizde uygulanan duruma kıyasla büyük bir farklılık teşkil etmektedir.

Bunlar haricinde, son bir önemli fark da, daha evvel de zikrettiğimiz üzere, Alman sistemi açısından, gelecekte gerçekleşme ihtimali bulunan, yani müstakbel, ceza muhakemeleri için de moleküler genetik inceleme yapılması olanağının tanınması ve verilerin ulusal DNA veri bankasında saklanmasıdır.

Türk ceza muhakemesi hukuku sistemimiz açısından yabancı olduğumuz, gelecekte gerçekleşme ihtimali bulunan muhakemeler için veri muhafazası ve toplu DNA incelemesi yöntemleri aşağıda detaylı olarak incelenecektir.

\subsubsection{Müstakbel Ceza Muhakemeleri İçin İnceleme Yapılması ve Ulusal DNA Veri Bankası}

Almanya'da ileride işlenebilecek olan suçların aydınlatılmasını amaçlayarak DNA profillerinin saklanmasına olanak tanındığı görülmektedir. ${ }^{92}$ StPO $§ 81 \mathrm{~g}$

91 CMK md. 75'te gecikmesinde sakınca olan hallerde şüpheli veya sanığın beden muayenesi veya vücuttan örnek alınması işlemleri hakkında Cumhuriyet savcısının da karar verebileceği düzenlenmiştir. Ancak alınan bu örnekler üzerinde moleküler genetik inceleme yapılabilmesi yalnızca hâkim kararı ile mümkün olmaktadir.

92 Aygörmez Uğurlubay (n 12) 34. Şunu da ifade etmek gereklidir ki, bu veriler, gelecekte işlenmesi muhtemel suçlar bakımından toplanan ve saklanan verileri ifade etmektedir. Zira ceza muhakemesi hukukuna ilişkin diğer kişisel veriler açısından StPO § 484 ve devamında yer alan hükümler uygulanmaktadır. Friedrich Christian Schroeder and Torsten Verrel, Ceza Muhakemesi Hukuku (Salih Oktar trs, Yetkin Yayınları, Ankara 2019) 76. 
düzenlemesi ${ }^{93}$ ile, cinsel özgürlüğe karşı veya başka önemli bir suç şüphelisinin varlığı durumunda, fiilin işleniş biçimi, şüphelinin kişiliği veya sair bilgilere göre, bu kişinin ileride önemli bir suçtan yargılanabileceğinin kabulünü gerektiren nedenler mevcutsa, gelecekte bu kişinin aleyhinde açılabilecek ceza davasında kullanılmak üzere, kimliğin veya cinsiyetin tespiti için moleküler genetik inceleme yapılabilmesine olanak tanınmıştır. Tekerrür durumu da bu kapsamda önemli suç kategorisine dâhil edilmiştir (StPO § 81g fikra 1). Görüldüğü üzere, yalnızca belli ağırlıktaki suçlar için tanınmış bir yöntem söz konusu olmaktadır. ${ }^{94}$

Amaçlanan bu hususlar çerçevesinde, artık gerek kalmaması durumunda, kişiden alınan örneklerin gecikmeksizin imha edileceği de düzenlenmiştir (StPO $§ 81 \mathrm{~g}$ fikra 2). Ancak imha gerekliliği haricinde, moleküler genetik inceleme sonuçları kayıt altında tutulmaktadır. Zira StPO § 81g fikra 5 ile, elde edilen verilerin Federal Suç Kolluğu Bürosu'nda kayıt altına alınabileceği ve Federal Suç Kolluğu Kanunu hükümlerine göre kullanılabileceği düzenlenmiştir. İşte bu düzenleme, Alman hukuku bakımından DNA veri bankasının temel yasal dayanağını oluşturmaktadır.

93 StPO 81g DNA tespiti

(1) Şüphelinin önemli bir suç işlediği veya cinsel özgürlüğe karşı bir suç işlediğinden şüphe ediliyorsa ve fiilin işleniş biçimi, şüphelinin kişiliği veya sair bilgilere göre, ileride önemli bir suçtan yargılanabileceğinin kabulünü gerektiren nedenler varsa, gelecekte aleyhinde açılabilecek ceza davasında kimliğin tesbiti için, şüphelinin bedeninden hücreler alınarak, DNA'sının ve cinsiyetinin tespiti amacı ile, moleküler genetik inceleme yapılabilir. Sair suçların tekraren işlenmesi, önemli bir suçun haksızlık içeriğine eşdeğerli sayılabilir. (2) Alınan vücut hücreleri sadece 1'inci fikrada belirtilen moleküler genetik incelemelerin yapılması amacı ile kullanılabilir; bu amaçla kullanılmasına gerek kalmadığı takdirde, geciktirilmeden imha edilir. Yapılan incelemede, DNA ve cinsiyetinin tespit edilmesi için yapılması gereken tespitlerin dışında başka bir tespit yapılamaz; bu yöndeki incelemeler dahi yasaktır. (3) Şüphelinin yazılı rızası olmaksızın, vücudundan hücre alınması, sadece mahkeme; gecikmesinde tehlike bulunan hallerde Savcılık ve savcılı̆̆ın dedektifleri (§ 152 Mahkemelerin Kuruluşu Kanunu) karar verebilir. Şüphelinin yazılı rızası olmaksızın, vücut hücreler üzerinde moleküler genetik inceleme yapılmasına, sadece mahkeme karar verilebilir. Rıza gösteren kişiye, elde edilecek olan verilerin hangi amaçla kullanılacağı öğretilir. 81 f madde 2'nci fikrası uygulanır. Mahkemenin yazılı olarak hazırladığı gerekçede, somut olaya ilişkin olarak aşağıdaki hususlara yer verilir: 1. Suçun önemli bir suç olup olmadığını değerlendirmek için belirleyici olgular, 2. Gelecekte şüpheli hakkında ceza muhakemesi yürütülebileceğini kabul etmeyi gerektiren bulgular ile 3. Her bir olayda esaslı şartların değerlendirilmesi. (4) Aşağıdaki hallerde 1 ile 3’üncü fikralar uygulanır: eğer ilgili kişi fiil nedeni ile kesin hükümle mahkûm olmuşsa veya sadece, 1 . kusur ehliyeti bulunmadığı ispatlandığı veya kusur ehliyetine sahip olup olmadığı şüpheli kaldığı için, 2. akıl hastalığına dayanan yargılanma ehliyetsizliği veya 3 . sorumluluğu bulunmadığı (işlediği fiilin hukuki anlam ve sonuçlarını algılayamaması) ( $\begin{aligned} & \S \\ & 3\end{aligned}$ Jugendgerichtsgesetzes) veya sorumluluğunun bulunup bulunmadığının şüpheli kalması nedeni ile, hakkında mahkûmiyet kararı verilememiş ise ve bu konuda Federal Adli Sicile veya Eğitim Siciline yapılmış olan kayıtlar, henüz silinmemiş ise. (5) Elde edilen veriler Federal Suç Kolluğu Bürosunda kayda alınabilir ve Federal Suç Kolluğu Kanunu hükümlerine göre kullanılabilir. Aynı hükümler, 1. bir şüpheli hakkında, 81e madde 1'inci fikrası uyarınca, 1'inci fikrada belirtilen koşullar altında toplanan veriler ile, 2. 81e madde 2'nci fikrası uyarınca toplanan veriler hakkında da geçerlidir. Veriler, ceza muhakemesi, tehlikenin önlenmesi ve milletlerarası adli yardım amaçları ile başka makama aktarılabilir. İkinci cümlenin 1 numaralı bendine giren hallerde, şüpheliye geciktirilmeksizin verilerin kaydedildiği bildirilir ve mahkeme kararı almak için talepte bulunma hakkı bulunduğu söylenir. Tercüme için bkz. Yenisey and Oktar (n 85) 66-69.

Aygörmez Uğurlubay (n 12) 63. 
Almanya'da DNA verilerinin gelecekte işlenebilecek suçların aydınlatılmasında kullanılmak üzere bu şekilde saklanması, AİHM tarafindan da incelenen bir konu olmuştur. Peruzzo ve Martens v. Almanya kararında ${ }^{95}$, başvuruculardan birinin çeşitli uyuşturucu suçları, diğerinin ise şiddet suçlarından ötürü mahkûmiyetlerinin ardından, DNA örneklerinin veri bankasına kaydedilmesinin, özel yaşamın gizliliği hakkı açısından ihlâl oluşturduğu iddiasıyla yapılan başvuru üzerine, açıkça dayanaktan yoksun olma gerekçesiyle başvurunun kabul edilemez olduğuna karar verilmiştir. Zira AİHM, ağır suçlardan mahkûm olan ve gelecekte aleyhine cezai işlemler yürütülebilecek olan kişilerin verilerinin saklanmasının, suçla mücadele bakımından önemli olduğunu belirterek, iç hukuktaki düzenlemelerin suistimallerin önüne geçecek şekilde yeterli olduğu ve kamu yararı ile özel kişilerin çıkarları arasında denge sağladığı sonucuna varmıştır.

Alman ceza muhakemesi doktrininde, DNA veri tabanlarının daha etkin bir şekilde kullanılabilmesi için yapılacak bir yasal düzenleme ile, kişilerden veri alınırken örnek sahibinin saç, göz ve ten rengi ile yaşının da belirlenebilir hâle getirilmesi önerilmekte ve bu sayede, kapsam dışında kalan diğer kişilere ait özel nitelikli verilerin daha fazla korunabileceği belirtilmektedir. ${ }^{96}$

Almanya Federal Suçlar Bürosu kayıtlarında belirtildiği üzere, 2019 yılının ilk çeyreği sonunda, INPOL (Das polizeiliche Informationssystem) Polis Bilgi Sistemi'nde kayıtlı olan DNA profillerinin sayıs1 1.207.907 olmuştur. ${ }^{97}$ Saklanan örnek sayısının makul düzeyde olması ve yasal metinler ile tüm prosedürün ayrıntılı olarak düzenlenmesi, kanaatimizce Almanya'da uygulanan sistemi, güvenlik kaygısı ağır basan, ancak özel nitelikli kişisel verilerin korunmasına da saygılı bir yaklaşım sergiler duruma getirmektedir.

\subsubsection{Toplu DNA İncelemesi}

Moleküler genetik incelemeler bahsinde, Alman ceza muhakemesi hukukunda tartışmalı bir husus teşkil etmekle birlikte kendisine yer bulan, ancak CMK'da karşı1l $\breve{g}_{1}$ olmayan bir diğer uygulama türü ise toplu DNA incelemesi (Massengentests) olarak

95 Antonio Peruzzo against Germany and Uwe Martens against Germany (Applications nos. 7841/08 and 57900/12).

96 Zöller and Thörnich (n 17) 340.

97 Ayrıntılı istatistik için bkz. <https://www.bka.de/DE/UnsereAufgaben/Ermittlungsunterstuetzung/DNAAnalyse/DNAstatistik/dnaStatistik_node.html> accessed 21 July 2019. 
adlandırılan yöntem olmaktadır. StPO $\S 81$ h'de düzenlenen bu yöntem ${ }^{98}$, çok sayıda kişinin bir suçun faili olma ihtimalinin bulunduğu durumlarda, hâkim kararına dayanarak bu kişilerden alınan örnekler üzerinde moleküler genetik inceleme yapılması usulüne dayanmaktadır. Örneğin, küçük bir yerleşim yerinde veya bir yurtta işlenen nitelikli cinsel saldırı suçu akabinde, o yerdeki şüpheli tüm erkeklerden alınacak DNA örnekleri üzerinde bu yöntem uygulanabilecektir.

Toplu DNA incelemesi, her suç açısından başvurulabilecek bir yöntem olarak düzenlenmemiştir. StPO $\S 81$ h'de açıkça belirtildiği üzere, hayata, vücut dokunulmazlığına veya cinsel dokunulmazlığa karşı bir suç işlendiği şüphesi bulunması hâlinde, gereklilik ve orantılılık ilkeleri de dikkate alınmak suretiyle, bu yönteme başvurulmasına izin verilmektedir. Üstelik, söz konusu işlemin yapılabilmesi için aranan şüphe, kanun tarafından "somut olgulara dayalı şüphe” olarak belirlenmiştir (§ 81h fikra 1).

Yasal düzenlemede ayrıca, kendisinden örnek alınacak olan ilgilinin yazılı rızasının bulunması şartına, işlemin yalnızca ilgili kişi sayısının çok fazla olması ve suçun ağırlığı ile mukayese edildiğinde ölçülülüğün sağlanması durumunda uygulanabileceğine ( $\$ 81 \mathrm{~h}$ fikra 1), işlemin gerçekleştirilebilmesi için mahkeme kararı bulunması gerektiğine ( $\$ 81 \mathrm{~h}$ fikra 2) ve en önemlisi, yönteme başvurulmasının sebebini oluşturan suç ile kişinin herhangi bir ilgisinin bulunmadığının tespit edilmesi durumunda, örneklerin gecikmeksizin silineceğine ve toplanan verilerin ileride yapilabilecek olan ceza muhakemelerinde kimlik tespiti amacı ile saklanmayacağına ( $§ 81 \mathrm{~h} \mathrm{fikra} \mathrm{4)} \mathrm{yer}$ verilmiştir.

98 StPO $\S 81 \mathrm{~h}$ Toplu DNA incelemesi

(1) Eğer somut olgular, hayata, vücut dokunulmazlığına, özgürlüğe veya cinsel yaşamını tayin özgürlüğüne karşı bir cürüm işlendiği şüphesini gösteriyorsa, failin taşıdığ 1 tahmin edilen inceleme özelliklerine uyan kişilerin, yazılı rızalarıyla ve olay yerinden elde edilen bulguların bu kişilerden kaynaklanıp kaynaklanmadığını tespit etmek için gerekli görülmesi ve uygulanacak bu tedbir, ilgili kişilerin sayısının çokluğu nedeni ile, suçun ağırlığına oranla, ölçüsüz olmayacaksa, 1. vücut hücreleri alınabilir, 2. bunlar, DNA-kimliğinin ve cinsiyetinin belirlenmesi amacı ile moleküler genetik açıdan incelenebilir ve 3. tespit edilen DNA-kimliğinin, olay yerinden elde edilen izlerdeki DNA-kimliği ile, otomatik olarak örtüşüp örtüşmediğinin belirlemek için otomatik olarak karşılaştırabilir. (2) Birinci fikra uyarınca bir tedbir uygulanabilmesi için, mahkemenin karar vermesi gerekir. Bu karar yazılı olarak verilir. Kararda, ilgili kişiler, inceleme özelliklerine dayanılarak tanımlanır ve karar gerekçelendirilir. İlgili kişilerin önceden dinlenmelerine gerek yoktur. Tedbire hükmeden karara karşı kanun yolu yoktur. (3) Tedbirin uygulanmasında 81f madde 2'nci ve 81g madde 2'nci fikraları uygulanır. Tedbirin uygulanması neticesinde elde edilen DNA-kimliği ile ilgili kayıtlara, cürümün aydınlatılması bakımından ihtiyaç duyulmadığı takdirde, bunlar geciktirilmeksizin silinir. Silme işlemi tutanağa bağlanır. (4) İlgili kişilere, tedbirin ancak rıza gösterdikleri takdirde uygulanabileceği, yazılı olarak öğretilir. Bu yazıda; 1. alınan vücut hücrelerinin sadece 1'inci fikrada belirtilen incelemelerin yapılması amacı ile kullanılacağı ve bunun için artık buna ihtiyaç duyulmadığ 1 takdirde, geciktirilmeksizin imha edileceği ve 2. tespit edilen DNA-kimliğinin, ileride yapılabilecek ceza muhakemelerinde kimlik tespiti amacı ile, Federal Suç Kolluğu tarafından bilgisayar ortamında saklanmayacağı, hususlarına yer verilir. Tercüme için bkz. Yenisey and Oktar (n 85) 69-71. 
StPO'nun bu düzenlemesi, şüphesiz ki suç failinin tespiti bakımından, özellikle de şüpheli konumundaki kişilerin sayısının fazla olduğu durumlarda, çok büyük bir kolaylık ve sürat sağlamaktadır. Kanaatimizce, maddenin detaylı bir şekilde düzenlenmesi ve inceleme sonucunda söz konusu suç ile ilgisi bulunmadığ 1 tespit edilen kişilerin verilerinin silinecek olması, esasında özgürlük ve güvenlik hususları arasında önemli bir denge kurulmasını da sağlamaktadır. Zira biyoteknolojinin sunduğu bu imkândan istifade ederek suç faillerini kısa sürede tespit etmek ve diğer yandan kişisel verilerin ihtiyaç kalmaması durumunda geciktirilmeksizin silineceğini bilmek, özel nitelikli kişisel verilere dair herhangi bir temel hak ihlâline yol açmayacaktır. Şayet ülkemiz açısından da toplu DNA incelemesi hususunda bir yasal düzenleme yapılması yoluna gidilecekse, StPO § 81h'nin bu detaylı düzenlemesi örnek alınabilecektir. Maalesef ki, özellikle cinsel istismar suçunun sıkça işlendiği bir ülke olarak, benzer bir düzenlemeye CMK'da yer vermemiz suç faillerinin kısa sürede tespit edilmesi ve gecikmeksizin cezalandırılması bakımından çok faydalı olacaktır.

\subsection{Birleşik Krallık}

\subsubsection{Yasal Düzenlemeler}

Moleküler genetik inceleme yönteminin uygulandığı ve sonuçların saklandığ1 ülkelerden bir diğeri Birleşik Krallık'tır. Hatta öyle ki, dünyanın en geniş kapsamlı DNA veri bankalarından birini Birleşik Krallık Ulusal DNA Veri Tabanı NDNAD (The United Kingdom National Criminal Intelligence DNA Database) teşkil etmektedir. ${ }^{99}$ Bu veri tabanı, 1994 yılında ülkede yürürlüğe giren Ceza Adaleti ve Kamu Düzeni Kanunu (Criminal Justice and Public Order Act) dayanak alınarak kurulmuştur. Polise, kanun uyarınca kaydedilebilir olarak sınıflandırılan DNA örneklerini rıza aranmaksızın toplama ve sistem üzerinden eşleştirme yapabilme yetkisi verilmiştir (md. 54). ${ }^{100}$ Polis bu yetkilerini, 1984 tarihli Polis ve Suç Delilleri Kanunu (Police and Criminal Evidence Act-PACE) hükümleri uyarınca kullanmaktadır. Zira farklı türdeki verilerin toplanmasına ilişkin hususlar esasen PACE ile düzenlenmiştir. ${ }^{101}$

NDNAD sistemi ilk oluşturulduğunda cinsel suçlara ilişkin veriler ağırlıkta olsa da 2003 yılına kadar sürekli genişleme yapılmasına olanak tanıyan yasal düzenlemeler ile sisteme tüm suçlardan, hatta en çok da hafif suçlardan mahkûm olan kişilerin verileri

99 Jason M Swergold, 'To Have and To Hold: The Future of DNA Retention in the United Kingdom' 33 (1) Boston College International and Comparative Law Review 179; Suterwalla (n 80) 186.

$100<$ https:/www.legislation.gov.uk/ukpga/1994/33/contents> accessed 21 July 2019.

101 Suterwalla (n 80) 186. 
kaydedilmeye başlanmıştır. ${ }^{102}$ Öyle ki, işlemeye başladıktan bir yıl sonra bile, olay yerinden toplanan örnekler, gözaltına alınan ya da tutuklanan kişilerden alınan örneklerden oluşan ve kişiler yargılama sonunda beraat etse dahi DNA verilerini saklamaya devam eden bu sistem, Birleşik Krallık İçişleri Bakanlığı verilerine göre yaş ve cinsiyete göre sınıflandırılmış şekilde, 6 milyondan fazla kişiye ait olan verileri kapsar hâle gelmiştir. ${ }^{103}$

NDNAD sisteminin kapsamının bu denli genişliğinden ziyade, AİHM'in S. ve Marper v. Birleşik Krallık kararı öncesine kadar, yarattığı en büyük problem yalnızca DNA profillerinin değil, üzerinde inceleme yapılan DNA örneklerinin de saklanması olmuştur. ${ }^{104}$ AİHM'in bu ünlü kararı ve kısa bir süre sonra yine aynı konunun ele alındığ 1 Goggins ve Diğerleri v. Birleşik Krallık kararının, ülkenin iç hukuku açısından yarattığı etkiler ise aşağıda ayrıntılı olarak incelenecektir.

\subsubsection{AİHM Kararlarının Birleşik Krallık Hukukundaki Etkileri}

Birleşik Krallık, DNA inceleme teknolojisinde kaydedilen ilerlemeden faydalanmak arzusuyla, yasal altyapısını buna uygun şekilde oluşturmuş olsa da, bu kapsamlı ve kalıcı veri saklama sistemi, özel yaşam, insan hakları ve devletin denetimi konularında pek çok endişeyi beraberinde getirmiştir. ${ }^{105} \mathrm{Bu}$ durumu sonlandıran husus ise, AİHM' in ünlü S. ve Marper v. Birleşik Krallık kararı olmuştur. ${ }^{106}$

Söz konusu davada, başvurucular temel olarak, kendileri hakkında beraat ve kovuşturmaya yer olmadığı kararları verilmiş olmasına rağmen, soruşturma ve kovuşturma işlemleri sırasında toplanan parmak izlerinin, hücre örneklerinin ve genetik profillerinin resmî makamlar tarafindan hâlen muhafaza ediliyor olmasının, AİHS md. 8 (özel yaşama ve aile yaşamına saygı hakkı) ve md. 14 (ayrımcılık yasağı) açısından ihlâl teşkil ettiği iddiasında bulunmuşlardır. ${ }^{107}$

102 Eleanor A M Graham, 'DNA reviews: the national DNA database of the United Kingdom' (2007) 3 (4) Forensic Science, Medicine, and Pathology 286.

103 Helen Wallace, 'The UK National DNA Database: Balancing crime detection, human rights and privacy' (2006) 7 EMBO Reports 26. Güncel sayllar için bkz. <https://www.gov.uk/government/statistics/nationaldna-database-statistics> accessed 23 July 2019.

104 Suterwalla (n 80) 192.

105 Robin Napper, 'A National DNA Database the United Kingdom Experience' (2000) 32 (2) Australian Journal of Forensic Sciences 66.

106 Case of S. and Marper v. The United Kingdom (4 December 2008. Applications nos. 30562/04 and 30566/04).

107 Başvuruculardan ilki 11 yaşında iken hırsızlık suçu nedeniyle yakalanmış, parmak izleri ve DNA örnekleri alınmış, yargılama sonucunda ise beraat etmiştir. İkinci başvurucu ise birlikte olduğu kişiyi taciz etmek suçlaması ile yakalanmış, onun da parmak izi ve DNA örnekleri alınmış, daha sonra şikâyetin geri alınması üzerine kovuşturmaya yer olmadığına karar verilmiştir. İki başvurucu da PACE uyarınca alınan ve NDNAD sistemine kaydedilen parmak izi ve DNA örneklerinin imha edilmesini talep etmişlerse de polis bu taleplerini reddetmiştir. 
Karara yansıdığı şekliyle, Birleşik Krallık hükümeti tarafından sergilenen yaklaşım, saklanan örneklerin daha sonra pek çok suç olayının aydınlatılmasında faydalı olduğuna vurgu yapılmak suretiyle, DNA örneklerinin muhafazasının özel yaşam ve aile yaşamına saygı hakkını hiç ihlâl etmediği ya da en azından çok hafif bir şekilde ihlâl ettiğinin belirtilmesi yönünde olmuştur. ${ }^{108}$ Buna karşıllı, başvurucular ise, bu örneklerin saklanmaya devam edilmesinin, bir kişi beraat etse dahi ondan şüphelenilmeye devam edildiği anlamına geldiğini ifade etmişlerdir ${ }^{109}$.

AİHM, değerlendirme yaparken öncelikle "özel hayat"1n sınırlı tanımı olmayan geniş bir kavram olduğunu ve bir kişinin hem fiziksel hem de ruhsal bütünlüğünü kapsadığını belirtmiştir. Zira AİHM genel anlamda, "özel hayat"ın her zaman için geçerli olacak bir tanımını yapmanın güç olduğunu ve bu nedenle önüne gelen her somut olayın kendine özgü koşullar içinde değerlendirilip özel hayat kavramına dâhil olup olmadığının belirlenmesi gerektiği ilkesini benimsemektedir. ${ }^{110}$

Gerek hücre örneklerinin gerekse moleküler genetik inceleme yöntemi sonucunda oluşuturulan DNA profillerinin, bu bakımdan kişisel veri niteliği taşıdığı ve özel yaşama dâhil olduğunu kabul eden AİHM, ayrıca DNA profilleri ile hücre örnekleri arasında bir ayrım yapmıştır. DNA profilleri, hücre örneklerinin incelenmesiyle üretilmekte ve bir şifre şeklinde ifade edilmektedir. Bu bakımdan daha az kişisel veri

108 Dava, istinaf mahkemesi önüne geldiğinde yargıç Lord Waller konuya ilişkin olarak; biyolojik örneklerin, parmak izlerine göre çok daha fazla ve detaylı kişisel veri barındırdığını, gelecekte bir gün örnekler üzerinde yapılacak bilimsel incelemelerin sonucunda bir kişinin bir suçu işlemeye ne kadar yatkın olduğunun belirlenebileceğini, saklanan örneklerin bu amaçla veya başka amaçlarla kullanılabilmesi için yasa değişikliği yapılabileceğini, hatta kanunun izin vermediği şekillerde kullanılması riskinin de bulunduğunu; ancak bunlara mukabil örneklerin saklanması sonucu yeni bir inceleme yapılmasına ve DNA belirtileri ortaya çıkararak veri tabanlarında hız, hassasiyet ve maliyete ilişkin avantajlar sağlanmasına, hukuki hata ya da araştırma ve tedavi hataları halinde ek inceleme yapılabilmesine imkân yaratılacağını, neticede bu avantajlar ile özgürlük arasında bir denge kurulması gerektiğini belirterek, her kanun ve uygulama değişikliğinin sözleşmeye uygun olması gerektiği, henüz ortada bulunmayan bir hukuka aykırılığın varmış sayılmasının yanlış olduğu, bu yüzden de sözü edilen risklerin büyük olmadığı, bu risklerin cezai fiillerin takip edilmesi ve önlenmesi açısından söz konusu olacak avantajlar ile telafi edileceği gibi tespitlerde bulunmuştur.

109 AİHM kararında bahsi geçen Nuffield Council on Bioethics (1991 yılında Nuffield Vakfı tarafından oluşturulan doktor, hukukçu, din adamı gibi kişilerden oluşan bağımsız bir kuruluş) raporunda; DNA verilerinin aile arayışı çerçevesinde kullanılmaya başlandığından, yani olay mahalinden alınan DNA örneklerinin ulusal veri tabanında kayıtlı olan örnekler ile karşılaştırıp uyum derecesine göre sınıflandırmasının yapıldığından bahsedilmiş, bu yolla yasaya aykırı şekilde akrabası ile evlenmiş kişilerin de tespit edildiği, tüm genetik ilişkilerin ortaya çıkarıldığı, ayrıca etnik köken değerlendirmesi yapıldığı belirtilmiştir.

110 Şeref Gözübüyük and Feyyaz Gölcüklü, Avrupa Insan Haklart Sözleşmesi ve Uygulaması (Turhan Kitabevi, Ankara 2009) 334. 
barındırmaktadır, ancak DNA profillerinin, bireyler arasındaki genetik ilişkilerin tespit edilmesini sağlayacak bir araç olmaları nedeniyle, bunların muhafaza ediliyor olması, bireyin özel yaşamına saldırı bulunduğuna karar verilmesi için yeterli görülmektedir. ${ }^{111}$ Genetik ve bilgi teknolojilerinde sürekli gelişmeler yaşanması karşısında bireyin, resmî makamlar tarafından muhafaza edilen özel bilgilerinin, gelecekte nasıl kullanılabileceğine ilişkin kaygı duyması meşru bir hak olarak kabul edilmiştir. AİHM tarafından, genetik bilgilere dayanan ve bugün için öngörülemeyen, ancak gelecekte var olabilecek özel yaşama müdahale ihtimalleri göz ardı edilmek istenmemiştir.

Sonuç olarak söz konusu davada AİHM, başvuruculara uygulandığı şekilde, suçlu olduğundan şüphelenilen fakat mahkûm edilmemiş kişilerin parmak izlerinin, biyolojik örneklerinin ve DNA profillerinin muhafaza edilmesinin genel ve farklılaştırılmamış niteliğinin, kamu çıkarları ve özel çıkarlar arasında adil bir denge sağlamadığını, söz konusu muhafaza etme işleminin, başvuranların özel yaşamlarına saygı gösterilmesi haklarına orantısız şekilde müdahale oluşturduğunu ve bunun demokratik bir toplumda gerekli olarak görülemeyeceğini belirtmiş ${ }^{112}$, bu nedenlerle hem hücre örneklerinin hem de DNA profillerinin muhafaza edilmesinin AİHS md. 8/1 kapsamında başvuranların özel yaşamlarına saygı gösterilmesi hakkına saldırı teşkil ettiği görüşüne varmıştır. AİHS md. 14 açısından ise ayrıca inceleme yapılmasına gerek olmadığına karar verilmiştir.

Anılan bu kararda yer verilen bir diğer önemli husus, kişisel verilerin kaydedilmesi ve kullanılması açısından bazı kriterlerin belirlenmiş olmasıdır. Buna göre, DNA örneklerinin de dâhil olduğu kişisel verilerin kaydedilebilmesi için bunun kanunla öngörülmüş olması, meşru bir amaca dayanması ve ayrıca demokratik toplum gereklerine uygun düşmesi gerekmektedir. AİHM, yasaların düzenlenişi bakımından, süre, stoklama, kullanım, üçüncü kişilerin erişimi, verilerin gizliliği ve bütünlüğü ile imhasına yönelik hususların ve bunlara aykırılık söz konusu olmaması için yeterince güvencenin sağlanmasını aramaktadır. Suçların tespit edilmesi ve önlenmesi meşru amaç olarak kabul görmektedir. Burada ilk etapta veri toplanması yoluyla belli bir kişi ile işlediğinden şüphe edilen suç arasında bağlantı kurmak amaçlanırken, verilerin muhafaza edilmesi, gelecekteki suçluların kimliğinin belirlenmesine yönelik olmaktadır. Üstün bir kamusal yararı karşılamak amacı varsa ve bu amaca ulaşmak için meşru ve orantılı bir şekilde müdahale uygulanıyorsa, bu takdirde demokratik toplumda gerekli olma koşulunun

111 Case of S. and Marper v. The United Kingdom (paragraph 75).

112 Case of S. and Marper v. The United Kingdom (paragraph 125); Suterwalla (n 80) 198. 
da sağlanmış olacağı belirtilmiştir. ${ }^{113}$

S. ve Marper v. Birleşik Krallık kararının iç hukukta önemli yansımaları olmuştur. 2012 yılında ülkede yürürlüğe giren Özgürlüklerin Korunmas1 Yasas1 (Protection of Freedoms Act) çerçevesinde, hakkında beraat hükmü verilen kişilerin verilerinin NDNAD sisteminden silinmesi kabul edilmiştir. ${ }^{114}$ Yalnızca bir suç nedeniyle mahkûm olan kişilerin DNA profillerinin ve parmak izlerinin saklanması imkânı kalacak şekilde daralmaya gidilmiştir. ${ }^{115} \mathrm{Bu}$ doğrultuda, Ceza Adaleti ve Kamu Düzeni Kanunu'nda yer alan, verilerin saklanmasına ilişkin md. 57 yürürlükten kaldırılmıştır. ${ }^{116}$ Birleşik Krallık İçişleri Bakanlığı tarafından hazırlanan ulusal DNA veri tabanına ilişkin yıllık raporda, kararın hemen ardından kabul edilen yeni yasanın uygulanması çerçevesinde NDNAD sisteminden 1 milyondan fazla kişinin DNA profilinin silindiği açıklanmıştır. ${ }^{117}$

Özgürlüklerin Korunması Yasası uyarınca getirilen bir diğer önemli yenilik de tüm DNA örneklerinin alındıktan sonraki altı ay içinde imha edilmesi gerekliliğinin tanınması olmuştur. Bu sürenin, verinin analiz edilmesi ve veri tabanında kullanılmak üzere profilinin üretilmesi açısından yeterli olduğu söylenebilecektir. ${ }^{118}$

S. ve Marper v. Birleşik Krallık kararında yalnızca DNA örneklerinin değil, diğer kişisel verilerin toplanması ve saklanması bakımından da önemli kriterler belirlenmiş olması hem Birleşik Krallık’ta gelecekte gerçekleştirilecek uygulamalar açısından hem de diğer ülkeler açısından önemli bir yol gösterici olma niteliği taşımaktadır. ${ }^{119}$ Fakat elbette ki bu kararı eleştirenler de bulunmaktadır. İngiliz doktrininde yer alan bir görüş tarafından, AİHM kararında, masum kişilerin verilerinin saklanmasına karş1

113 Case of S. and Marper v. The United Kingdom (paragraph 99).

$114<$ https://assets.publishing.service.gov.uk/government/uploads/system/uploads/attachment_data/file/320005/ 9781474106412_WEB.pdf> accessed 23 July 2019.

115 Namık Kemal Topçu, Ingiliz Ceza Muhakemesi Hukukunda Soruşturma Evresi (Adalet Yayınevi, Ankara 2018) 105.

$116<$ https://www.gov.uk/government/publications/protection-of-freedoms-act-2012-dna-and-fingerprintprovisions--2/protection-of-freedoms-act-2012-dna-and-fingerprint-provisions-january-2019> accessed 23 July 2019.

117 National DNA Databse Strategy Board Annual Report 2012-13<https:/www.gov.uk/ government/uploads/ system/uploads/attachment_data/file/252885/NDNAD_Annual_Report_2012-13.pdf $>$ accessed 23 July 2019.

118 Topçu (n 116) 105. Süreler konusunda ayrıntılı tablo için bkz. < https://www.gov.uk/government/ publications/ protection-of-freedoms-act-2012-dna-and-fingerprint-provisions/protection-of-freedoms-act-2012-howdna-and-fingerprint-evidence-is-protected-in-law> accessed 20 July 2019.

119 Suterwalla (n 80) 204. 
çıkılmasının, daha fazla sayıda verinin muhafaza edilebilmesi ve ileride işlenebilecek suç faillerin tespiti imkânları bakımından engel teşkil ettiği ve ayrıca, AİHM'in diğer ülke örneklerine çok fazla atıfta bulunmasının, İngiltere'nin sahip olduğu teknoloji ile kıyaslandığında bu ülkelerin imkânlarının kısıtlı olması nedeniyle, doğru bir mukayese teşkil etmediği belirtilmiştir. ${ }^{120}$ Buna mukabil, kararda belirtilen hususları destekleyenler, AIIHM tarafından sergilenen yaklaşımın, demokratik bir devlet ile polis devleti arasındaki farkları ortaya koymaya hizmet ettiğini ve üzerinde durduğu hususların son derece yerinde olduğunu savunanlar da bulunmaktadır. ${ }^{121}$

Birleşik Krallık aleyhine, S. ve Marper davasından sonra, yine DNA örneklerinin saklanması konusunu esas alan bir diğer önemli dava, Goggins ve Diğerleri v. Birleşik Krallık $^{122}$ davası olmuştur. Bu davada 8 ayrı başvurucu, DNA örneklerinin, parmak izlerinin ve bunlarla ilintili verilerin toplanması ve saklanmasının, AİHS md. 8. açısından ihlâl teşkil ettiğinden yakınmıştır. ${ }^{123}$

Birleşik Krallık, savunmasında, Mayıs 2010 tarihli hükümet planında, DNA veri tabanları için İskoç modelinde düzenlenen koruma yöntemlerinin benimseneceğine yer verildiğini ifade etmiştir. Bu yaklaşımın gerekçesi olarak ise, AİHM tarafından S. ve Marper davası açısından inceleme yapılırken, Avrupa Konseyi Bakanlar Komitesi’nin

120 Bu yöndeki görüşler için bkz. Swergold (n 100) 196-197.

121 George J Annas, 'Protecting Privacy and the Public-Limits on Police Use of Bioidentifiers in Europe' (2009) 361 (2) The New England Journal of Medicine 201.

122 Case of Goggins and Others v The United Kingdom (19 July 2011. Applications nos. 30089/04, 14449/06, 24968/07, 13870/08, 36363/08, 23499/09, 43852/09 and 64027/09).

$123 \mathrm{Bu}$ kişilerden, cinsel saldırı ve çevreye rahatsızlık vermek gibi çeşitli suçlar sonucunda veya sebebi tam olarak belirlenemeyen șekilde polis tarafından parmak izi ve DNA örnekleri alınmıștır ve bu kișilerin fotoğrafları çekilmiştir. Bu işlemler 1984 tarihli "Police and Criminal Evidence Act (PACE)"e dayanılarak yapılmıştır. Bu kişilerden bazıları yalnızca gözaltına alınıp bırakılmış, bazıları hakkındaki suçlamalar daha sonra düşürülmüştür, fakat hepsinin ortak noktası; kişilerden alınan örneklerin daha sonra imha edilmemiş olmasıdır. 
(92) 1 sayılı tavsiye kararında ${ }^{124}$ belirtilen hususlara en uygun modelin İskoç modeli ${ }^{125}$ olduğununun belirtilmesi gösterilmiştir.

AİHM, Goggins ve Diğerleri davası bakımından da, kendisinden şüphe edilen, fakat suçu işlediği kanıtlanmamış olan kişilerin, hücre örnekleri ve DNA profillerinin saklanmasının, kamusal çıkarlar ile bireysel çıkarlar arasında bulunması gereken adil dengeyi bozduğunu belirtmiş̦tir. Bu nedenle, verilerin saklanmasının başvurucuların özel yaşamın gizliliğine saygı duyulması hakkına uygunsuz bir müdahale teşkil ettiğini ve bunun demokratik toplumun gerekliliklerine aykırı olduğunu ifade etmek suretiyle, AİHS md. 8 açısından ihlâl bulunduğuna karar vermiştir.

AİHM ayrıca, DNA profillerinin, kişiye isnat edilen suçun niteliği ve önemi veya

124 Avrupa Konseyi Bakanlar Komitesi’nin, “Ceza Yargılaması Sistemi Çerçevesinde DNA Analizlerinin Kullanılması" başlıklı R (92) 1sayılı, 10 Şubat 1992 tarihli tavsiye kararı. Kararın orijinal metni için bkz. $<$ https://wcd.coe.int/com.instranet.InstraServlet? command=com.instranet. CmdBlobGet\&InstranetImage $=1518265 \&$ SecMode $=1 \&$ DocId $=601410 \&$ Usage $=2>$ accessed 23 July 2019. (92) 1 sayılı tavsiye kararında; DNA analiz yöntemlerinde yaşanan teknik gelişmelerin sağladığı avantajlar karşısında kişi temel hak ve özgürlüklerinin korunması açısından oluşturulması gereken denge esas alınmıştır. Kararın ikinci maddesi, bu tür uygulamaların bir suç soruşturması veya kovuşturması çerçevesinde gerçekleştirilebileceğini belirterek öncelikle konuya ilişskin bir sınırlama getirmiştir. 3. maddede amaca bağl1lık kuralı getirilerek, verilerin soruşturma veya kovuşturma işlemleri dışında kullanılamayacağı belirtilmiş, bunun tek istisnası olarak veri sahibi kişinin kendisine verilmesi talebinde bulunması gösterilmiştir. Medikal amaçlar ile kişilerden alınan örneklerin soruşturma veya kovuşturma amaçlarıyla kullanılamayacağ belirtilmiştir. Ayrıca, bu verilerin istatistiki amaçlarla kullanılmasına da izin verilebileceği, fakat bunun için bireyin kimliğinin kesinlikle tespit edilemeyeceği durumun yaratılması istenmektedir. Tavsiye Kararı'nın veri korunmasına ilişkin 7. maddesinde; elde edilen verilerin, Veri Koruma Sözleşmesi'ne, özellikle polis işlemleri açısından veri korunmasına iliş̧kin tavsiye kararına ve diğer tüm tavsiye kararlarına uygun biçimde, yani kısacası Avrupa Konseyi standartlarına uygun biçimde korunması gerektiği ifade edilmiştir. Tavsiye Kararı'nda ayrıca; bireylerden alınan DNA örneklerinin ilgili davada kullanılıp nihai kararın oluşturulması ardından, bağlantılı amaçlar ile kullanılması lazım değilse saklanmayıp silinmesi ve bunu sağlayacak tedbirlerin alınmasının gerekliliği belirtilmiş̦tir (md. 8). Bununla birlikte aynı maddede, DNA analiz sonuçlarının ve bunlardan kaynaklanan diğer bilgilerin; veri sahibinin, diğer kişilerin hayatına, vücut bütünlüğüne veya güvenliğine yönelik ciddi suçlar nedeniyle mahkûm olması durumunda saklanmaya devam edilebileceği, bu tür veri depolama işlemlerinin iç hukukta düzenlenmiş olması gerektiği belirtilmiştir. Uzun süre muhafaza edilebilecek veri kategorisinde ise; kişinin bu konuda isteğinin bulunması durumu ve olay yerinde bulunup da bir birey ile ilişkilendirilmemiş örnek bulunması durumu gösterilmiştir. Madde 8 ayrıca, devlet güvenliği söz konusu olduğunda, üye devletlerin iç hukukunun verilerin saklanmasına izin verebileceğini belirtilmiştir. Bunun anlamı, bir suçtan mahkûm edilmemiş kişilerin bile verilerinin saklanabileceğidir. Tabii böyle durumların, sıkı koşullar ile iç hukukta düzenlenmiş olması ihtiyacı bulunmaktadır.

125 İskoç modelinde; DNA, parmak izi ve diğer fiziksel deliller polis tarafından, verinin alınmasını gerektiren olayla bağlantılı işlemlerin tamamlanması tarihinden itibaren 3 yıl boyunca saklanabilmektedir. Bu sürenin sonunda gerekli görülmesi halinde Emniyet Müdürü bu verilerin 2 yıla kadar daha saklanmasına karar verebilir ve bu uzatma işlemi her dönem sonunda tekrarlanabilir. Sistemin çalışma prensibi gereği bir verinin saklanmaya başlaması tarihinden itibaren 3 yılın dolması yaklaşınca uyarı yapılmaktadır. Bu aşamada Emniyet Müdürü, verinin daha uzun süre saklanmasına gerek olup olmadığına karar vermektedir. Bu karar, veri sahibi kişinin kamu açısından yarattığı tehlike dikkate alınarak verilmektedir. İmha kararı verilirse hem örnekler hem de bunlara göre oluşturulan profiller imha edilecektir. Süre uzatım kararına karşı, verisi saklanan bireyin 21 gün içinde şerif müdürüne başvurma imkanı vardır. Eğer başvurusu kabul edilirse, kişinin verileri en kısa zaman içinde yok edilir. Bu konuda ayrıntılı bilgi için bkz. Guidance on the Retention and Use of Forensic Data and Samples Under the Provisions of the Criminal Procedure (Scotland) Act 1995 and the Criminal Justice (Scotland) Act $2003<$ http://www.scotland.gov.uk/ Resource/Doc/347326/0115604. pdf $>$ accessed 23 July 2019. 
şüpheli ya da sanığın yaşı dikkate alınmadan saklanmasının masumiyet karinesini zedelediğini, çünkü bu verilerin mahkûm olan kişiler ile aynı yöntem uygulanarak elde edildiğini vurgulamış ve tüm bunların hukuka aykırılık teşkil ettiğini belirtmiştir. ${ }^{126}$ Özel yaşama ilişkin diğer kararlarında da gördüğümüz üzere AİHM, kişisel veriler ne şekilde elde edilmiş olursa olsun, sonradan kullanılıp kullanılmamalarından da bağımsız olarak, resmî makamlar tarafından muhafaza edilmeleri ya da kaydedilmelerinin, yani sistematik olarak biriktirilmelerinin, ilgili bireyin özel hayatı bakımından doğrudan sonuçları olacağını kabul etmektedir.

Her iki kararda da gördüğümüz üzere AİHM, suçla mücadele konusunda yöntemin faydalarını da vurgulamakla birlikte, muhafaza etme işleminin süreyle sınırlı olmaması, delillerin suç işlediğinden şüphe edilen kişinin, işlediği suçun türü ve ağırlığından bağımsız şekilde muhafaza edilmesini kabul etmemektedir. Özellikle beraat etmiş bir kişinin, ulusal DNA veri tabanındaki örneklerinin silinmesini ya da imha edilmesini talep edebilmesi için herhangi bir imkânın bulunmaması ya da böyle bir imkân varsa da yetersiz kalmasını da ihlâl olarak kabul etmektedir. Belirlenen bu kriterlere uygunluk, özel nitelikli kişisel verilerin uluslararası standartlarda korunması bakımından büyük önem taşımaktadır. Bu nedenle, kanaatimizce, ülkemizde bir DNA veri bankası kurulması durumunda, mukayeseli hukuk örnekleri ile birlikte AİHM tarafından belirlenen standartlara uygunluğun sağlanması da büyük bir önem arz etmektedir.

\subsection{Amerika Birleşik Devletleri}

Moleküler genetik inceleme yöntemine sıkça başvurulan ve bu hususta oldukça gelişmiş bir teknolojiden yararlanan ülkelerden biri de Amerika Birleşik Devletleri olmaktadır. Öyle ki, dünyanın en büyük DNA veri tabanı, Federal Soruşturma Bürosu FBI'ın CODIS (Combined DNA Index System) olarak adlandırılan sistemidir ve bu sistem ABD'de bulunan, yerel ölçekli, eyalet düzeyindeki ve federal suç laboratuvarlarının tümü arasında, analiz sonuçlarının iletimi, birbirleriyle karşılaştırılması ve suçlar arasında bağlantı kurulmasına olanak sağlamaktadır. ${ }^{127}$ CODIS verileri üzerinden ayrıca, kayıp kişilerin bulunması, kimlik tespiti ve kimlik tespiti yapılamadığı durumlarda ise aile araştırması amaçlarıyla da sorgulama yapılabilmektedir. Ancak aile araştırması, birinci derece yakınlar ile sınırlı tutulan istisnai bir uygulama olarak kabul edilmektedir. ${ }^{128}$

126 Ayhan Bozlak, Avrupa İnsan Hakları Mahkemesi Kararları Çerçevesinde Türk Ceza Hukukunda Özel Hayatın Korunmast (Adalet Yayınevi, Ankara 2013) 101.

$127<$ http://www.fbi.gov/about-us/lab/biometric-analysis/codis> accessed 22 July 2019.

$128<$ http://www.fbi.gov/about-us/lab/biometric-analysis/codis> accessed 22 July 2019. 
Sisteme kaydedilen veriler, federal bir suç nedeniyle gözaltına alınan ve tutuklanan her kişi ile gönüllülere ait DNA örneklerinin analizinden oluşmaktadır. Veri sahibi kişinin, yargılama sonunda beraat etmesi veya ceza muhakemesinin düşme kararı ile sonlanması durumlarında, kendisinin veya yasal temsilcisinin yazılı başvurusu yolu ile sistemden silinmeyi talep etme hakkı bulunmaktadır. Bu yöndeki talep hakkı, 2005 yılında yürürlüğe giren DNA Parmak İzi Yasası (DNA Fingerprint Act) ile tanınmıştır. Ancak talepte bulunan kişi sayısının azlığı nedeniyle, sistemdeki veri sayısında pek azalma yaşanmadığ 1 da belirtilmektedir. ${ }^{129}$

ABD'de 1990 y1lında 14 eyalette başlatılan pilot bir uygulama olan CODIS, zaman içinde 50'den fazla ülkenin kullandığı bir yazılım hâline dönüşmüştür ve dünyanın en gelişmiş DNA veri bankası sistemini oluşturmaktadır. Bu sistemde, veri sahiplerini belirleyecek isim, doğum tarihi veya sosyal güvenlik numaras1 gibi bilgiler yer almamaktadır. DNA profili, incelenen numunenin numarası ve DNA analizini yapan personelin bilgilerinden oluşacak şekilde muhafaza edilmektedir. Ayrıca, özel nitelikli kişisel verilerin güvenliğini sağlamak adına, söz konusu bu sisteme yalnızca CODIS kullanmaya yetkili ve FBI tarafından onaylanmış kişilerin giriş yapmasına izin verilmektedir. Verilerin hangi kişiye ait olduğunun belirlenmesini sağlayan tüm unsurlar ortadan kaldırıldıktan sonra, bu verilerin istatistikî amaçla kullanımına da izin verilebilmektedir. ${ }^{130}$

Amerikan Sivil Özgürlükler Birliği (ACLU) tarafindan, teknolojiden yararlanmanın gereklerine olan inançla birlikte, DNA veri tabanlarındaki her genişlemenin ve her yeni kullanım türünün özel yaşama dair çok daha fazla gizlilik ihlâli yaratacağından endişe duyulduğu ifade edilmiş ve bu nedenle CODIS'e de temkinli yaklaştıkları belirtilmiştir. Zira ifade ettikleri üzere, şüphelilerden alınan veriler ile oluşturulan toplu bir DNA veri tabanının, belki biraz mübalağalı da olsa, "cesur yeni dünya" $\mathrm{da}^{131}$ olduğu gibi, genetik bilginin rutin olarak toplanmasının suistimal ve ayrımcılığa yol açacak biçimde kullanıldığı bir oluşum yaratması ihtimali bulunmaktadır. ${ }^{132}$

$129<$ https://www.nij.gov/topics/forensics/evidence/dna/pages/collection-from-arrestees.aspx> accessed 26 July 2019.

$130<$ http://www.fbi.gov/about-us/lab/biometric-analysis/codis> accessed 22 July 2019.

131 Aldous Huxley’in Cesur Yeni Dünya adlı romanında, biyoteknolojinin insan doğasını tamamen değiştirebilecek hâle geldiği bir dünya düzeninden bahsedilmektedir. Romanda, istenilen özelliklere sahip insanların yaratıldığı ve bunların ne kadar "insan” olduğunun sorgulandığı bir dünya kurgulanmıştır.

$132<$ https://www.aclu.org/technology-and-liberty/aclu-warns-privacy-abuses-government-plan-expand-dnadatabases> accessed 23 July 2019. 
FBI ise, CODIS üzerindeki verilerin gizliliğinin sağlandığını ve bu yazılımın, fiziksel olarak güvenli bilgisayarlarda bulunduğunu, ayrıca sisteme erişimin yalnızca onu kullanmaya yetkili ve FBI tarafından onaylanan kişilerle sınırlı olduğunu, bu doğrultuda yalnızca ceza adaleti kurumlarının erişebileceği bir alan ağının kurulduğunu belirtmekte, sisteme izinsiz olarak girilmesi veya verilerin ifşa edilmesi durumunda ise 250.000 \$'a kadar para cezası uygulanacağına dikkat çekmektedir. ${ }^{133}$ Doktrinde, her ne kadar internet çağında hiçbir elektronik veri tabanının üst düzeyde güven sağlayamayacağı belirtilse de, CODIS'e ilişkin olarak kişisel verilerin korunması ya da özel yaşamın gizliliği bakımından, aleni veya gizli herhangi bir ihlâlin yaşanmadığına dikkat çekilmekte, bu nedenle de sırf verilerin sistemde saklanıyor olmasının bir tehdit oluşturduğunu ifade etmenin makul olmadığı dile getirilmektedir. ${ }^{134}$

Aktarılan durum karşısında, ABD'de uygulanan sistem açısından, kişisel verilerin korunması bakımından önemli tedbirler alındığı, ancak temel eksikliğin verilerin silinmesi konusunda yaşandığını görmekteyiz. Zira beraat eden kişilerin, sisteme kayıtlı olan verilerinin otomatik olarak silinmesi yerine, bu kişilere bir külfet yaratılarak talep mecburiyetinin getirilmesi, talepte bulunulmadığı sürece kişisel verilerin yasal olsa da, adil olmayan bir şekilde, muhafazasına devam edilmesi anlamı taşımaktadır.

\subsection{Diğer Bazı Ülkeler}

Avrupa Birliği üyesi ülkelerin sınıraşan suçlar ve terörle mücadele gayeleri ile DNA profillerini paylaştıkları Prüm Sistemi ${ }^{135}$ haricinde, Avrupa Konseyi üyesi devletlerin çoğu, ceza muhakemesinde etkinliğin sağlanabilmesi adına, kendi iç hukuklarında moleküler genetik inceleme yöntemine ilişkin yasal düzenlemelere sahip olarak bu yöntemi uygulamakta ve kurdukları ulusal DNA veri bankalarından istifade etmektedirler.

Bu ülkelerden biri olan Fransa'nın, DNA veri bankası FNAEG'de (Fichier National des Empreintes Génétiques), 2018 y1lı verilerine göre, 2,9 milyon veri yer almaktadır. ${ }^{136}$ Bu veri tabanının oluşturulmasının amaçları, ceza muhakemesinde etkinliği sağlamak ve kayıp kişilerin bulunması olarak belirtilmiştir. Ceza muhakemesi hukuku açısından,

$133<$ https://www.fbi.gov/services/laboratory/biometric-analysis/codis/codis-and-ndis-fact-sheet> accessed 23 July 2019.

134 Patrick Haines, 'Embracing the DNA Fingerprint Act' (2007) 5 Journal on Telecommunications and High Technology Law 651.

135 Konu hakkında ayrıntılı bir inceleme için bkz. Filipe Santos and Helena 'Machado, Patterns of Exchange of Forensic DNA Data in the European Union Through the Prüm System' (2017) 57 (4) Sci Justice 307.

$136<\mathrm{https}: / /$ www.cnil.fr/fr/fnaeg-fichier-national-des-empreintes-genetiques > accessed 22 July 2019. 
Fransız Ceza Muhakemesi Kanunu'nun 706-55 maddesinde yer alan listede gösterilen, insanlığa karşı suçlar, işkence, yaralama ve uyuşturucu suçları gibi bazı ağır suçların faillerinin DNA profilleri FNAEG'de saklanmaktadır. ${ }^{137}$

FNAEG sistemi üzerinde saklanan DNA profillerinin, kişisel verilerin korunması açısından ortaya koyduğu durum, AİHM içtihadına da yansıyan bir husus olmuştur. AİHM, Aycaguer v. Fransa kararında ${ }^{138}$, basit bir yaralama nedeniyle iki aylik hapis cezasına mahkûm edilen başvurucunun DNA örneklerinin FNAEG sistemine kaydedilmesini reddetmesi nedeniyle para cezasına mahkûm edilmesinin, AİHS md. 8 kapsamında özel yaşamın gizliliği hakkını ihlâl ettiğine karar vermiştir. Zira AİHM, bazı ağır nitelikli suçların faillerinin sisteme kaydedilmesini makul görürken, en hafif suçlarda bile sisteme kayıt yönteminin amacı aştığını, üstelik verilerin silinmesini talep etme hususunda herhangi bir düzenleme öngörülmemiş olmasının demokratik bir toplumun gereklerine aykırılık teşkil ettiğini belirtmiştir. ${ }^{139}$

$137<$ https://www.cnil.fr/fr/fnaeg-fichier-national-des-empreintes-genetiques> accessed 22 July 2019.

138 Case of Aycaguer v. France (22 June 2017. Application no. 8806/12).

139 Karara konu olayda başvurucu, katıldığı bir mitingde göstericiler ve jandarma arasında yaşanan gerginlik sırasında gözaltına alınmış, elindeki şemsiye ile jandarmalardan birini yaraladığı iddiasıyla yargılanmış, suçlamaları ve hatta bir şemsiye taşıdığını inkar etmesine rağmen, iki aylık hapis cezasına mahkûm edilmiştir. Mahkûmiyeti nedeniyle başvurucudan DNA örneği alınmak istenmiş, ancak başvurucu bunu reddetmiş̧ir ve bu gerekçeyle ayrıca yargılanmış ve bu kez de para cezasına mahkûm edilmiştir. Başvurucunun kararı iç hukukta temyiz etmesi üzerine, temyiz mercii AİHM'in S. and Marper v. United Kingdom kararına atıf yapmış, ancak somut olayda başvurucu hükümlü bir kişi olduğundan, konunun farklı şekilde değerlendirilmesi gerektiğine vurgu yapmış ve kararı onamıştır. İç hukuk yollarının tüketilmesi ardından, biyolojik örneklerinin FNAEG sistemine kaydedilmek istyenmesinin ve bunu reddetmesi nedeniyle cezalandırılmasının AİHS md. 8'in ihlal edildiği gerekçesi ile başvurucu AİHM'e başvurmuştur. FNAEG cinsel suç faillerine ilişkin DNA profillerinin saklandığı bir sistem iken zamanla neredeyse tüm suçları kapsayacak şekilde genişletilmiştir ve en ağır suçlardan en hafif suçlara kadar hepsini kapsayacak bu şekildeki bir genişleme meşru kabul edilemeyecektir. İşlediği suçun niteliği göz önünde bulundurulduğunda DNA örneğinin kırk yıl boyunca saklanmasının orantısız olduğunu (parag 22), üstelik devletin neden böyle bir saklama ihtiyacı duyduğunu açıklamak konusunda yetersiz kaldığını (parag 23) ileri sürmüştür. Ayrıca, veri bankasının bağımsızlık garantisinden uzak olduğu, çünkü savcı denetiminde olduğuna da vurgu yapıllmıştır (parag 24). Başvurucunun bu diiaları karşısında hükümet, özel yaşamın gizliliği hakkına bir müdahalenin söz konusu olduğunu inkar etmemekle birlikte, bunun yasal bir zemine dayandırıldığını ifade ederek savunma yapmıştır (parag 26). FNAEG sisteminin Anayasa Konseyi tarafından onaylanmış olduğunu, düzensizliğin ve suçun önlenmesi meşru amacına odaklanmış olduğunu ifade etmiştir (parag 27). Hükümet ayrıca, maksimum veri saklama süresinin kırk yıl olması nedeniyle, mahkûmların verilerin silinmemesinin herhangi bir ihlale yol açmadığını, veri sahibine herhangi bir yükümlülük getirmediğini ve yalnızca tekerrür durumlarında kullanıldığını belirtmiştir (parag 31). AİHM değerlendirmesinde, özellikle FNAEG'nin kuruluş amacına uygun şekilde, cinsel suç faillerinin cezalandırılması ve bu suçların önlenmesine yardımcı veri bankalarının oluşturulmasını olumlu karşıladığını, ancak bunun genişletilerek veri toplama imkanının tüm suçlara yayılmasının ve muhafaza süresinin uzatılmasının bir ihlal olduğunu belirtmiştir (parg 34). Saklanan verilerin silinmesine ilişkin bir başvuru imkanının tanınmamış olması da verilerin korunması açısından kamu yararı ile özel çıkarlar arasında bir denge kurulamaması anlamına gelecek şekilde yorumlanmıştır (parag 45). Neticede AİHM, bu koşullar altında başvurucunun DNA veri tabanı sistemine kaydedilmeyi reddetmesi nedeniyle mahkûm edilmesinin, Sözleşme md. 8'i açıkça ihlal ettiğini, özel yaşamın gizliliği hakkına yönelik orantısız bir müdahale teşkil ettiğini ve bu nedenle demokratik bir toplumda gerekli olduğunun savunulamayacağını gerekçe göstermek suretiyle, Sözleşme'nin 8'nci maddesinin ihlal edildiğine karar vermiştir. 
Yine Avrupa Konseyi üyesi ülkelerden olan İtalya'da, 2009 y1lında yürürlüğe giren kanun ile İtalyan Ulusal DNA Veri Bankası kurulmuştur. Bu veri bankasında, CODIS ile aynı yazılım kullanılarak olay yerinden ve ilgili kişilerden alınan DNA örneklerinin mukayesesi yapılabilmektedir. ${ }^{140}$ İtalya açısından, özel nitelikli kişisel verilerin korunmasına ilişkin olarak dikkat çekilen bir önlem, ilgili ceza davası ile bağlantısı olan herhangi bir kişinin bu sisteme doğrudan erişimine izin verilmemiş olması şeklinde açıklanmaktadır. ${ }^{141}$

Avrupa Konseyi'nin diğer üye ülkeleri Belçika'da, kanunda gösterilen belirli ağır suç faillerinin DNA profilleri mahkûmiyet durumunda 30 yıl boyunca saklanmakta; İrlanda'da beş yıldan fazla hapis cezasını gerektiren suçların mahkûmlarının DNA örnekleri sınırsız süreyle saklanmakta; Danimarka'da ise belli suçlardan mahkûm olan kişilerin DNA profilleri bu kişilerin ölümünden iki yıl sonrasına veya ilgili kişinin seksen yaşına kadar saklanmaktadır. ${ }^{142}$ Kısaca değindiğimiz bu ülkeler, Avrupa Konseyi üyesi olmaları nedeniyle belirlenen uluslararası kriterlere uygunluk dışında, kendi iç hukuk sistemlerinde gerek moleküler genetik inceleme yöntemi gerekse ulusal DNA veri bankaları bakımından birbirinden oldukça farklı esaslar uygulamaktadır. ${ }^{143}$

Ulusal DNA veri bankasına sahip olan ülkeler arasında farklı bir uygulama benimseyen Kanada'da ise, DNA veri bankasının farklı kategorileri esas alan bir tasnife dayandığ 1 görülmektedir. Bu sistem 2000 yılında kurulduğunda, hükümlülerin DNA profillerinden oluşan hükümlü DNA veri endeksi ve Kanada genelindeki olay yeri inceleme ekipleri tarafindan elde edilen bulgulardan oluşan suç mahalli endeksi olmak üzere, iki ayrı endeks üzerinden veri girişi yapılırken, 2018 yılında DNA Kimlik Belirleme Kanunu'nda yapılan yasal değişiklik ile bunlara beş yeni endeksin daha eklendiği belirtilmektedir. Bunlar; mağdur endeksi, gönüllü donör endeksi, kayıp kişiler endeksi, kayıp yakınları endeksi ve insan kalıntıları endeksi olarak belirlenmiştir. Böyle bir ayrımın yapılmasının, ceza adalet sistemi içinde çalışan kişilere, olayların çözümünde ek imkânlar sunduğu

140 Renato Biondo and Francesco De Stefano, 'Establishment of Italian national DNA database and the central laboratory: Some aspects’ (2011) 3 (1) Forensic Science International: Genetics Supplement Series 236.

141 Ibid 236.

142 Filipe Santos, Helena Machado and Susana Silva, 'Forensic DNA Databases in European Countries: Is Size Linked to Performance?’ (2013) 9 (12) Society and Policy <http://www.lsspjournal.com/content/9/1/12> accessed 23 July 2019.

143 Avrupa Konseyi standartları çerçevesinde İsviçre hukukunda veri tabanlarının ele alınışına ilişkin kapsamlı bir inceleme için bkz. Begüm Bulak Uygun, 'Databases and Criminal Procedures in Switzerland and Turkey with Regard to European Council's Standarts' (2017) 5 (2) Ceza Hukuku ve Kriminoloji Dergisi (Journal of Penal Law and Criminology). 
ifade edilmektedir. ${ }^{144}$ Gerçekten de bu şekilde bir kategorizasyon, sisteme kayıtlı DNA profilleri üzerinden araştırma yapacak olan görevlilerin işlerini kolaylaştırıp sonuca ulaşmak bakımından hız sağlarken, bir yandan da araştırma yapılan kategori dışında kalan kişilerin özel nitelikli verileri üzerinden uğrayabileceği hak ihlâllerini en düşük seviyeye çekmektedir. Belirtilen nedenlerle, DNA veri bankası sistemlerinde yapılacak olan tasniflerin faydalı olduğunu düşünmekteyiz.

Görüldüğg̈ üzere, gelişmiş ülkelerde DNA veri tabanlarında, özel nitelikli kişisel veri kategorisinde yer alan DNA profilleri, ceza muhakemesi işlemleri sırasında ilgiliden alınmak suretiyle veya diğer yollar ile elde edilmekte ve saklanmaktadır. Bu hususta her ülkenin kendine özgü bir sistemi bulunduğu da dikkat çekmektedir. Öyle ki, kimi ülkeler kullanıma ihtiyaç duyulmayan verileri sistemlerinden silerken, kimi ülkeler ise veri sahibinin ölmesinden sonra dahi belli bir süre boyunca muhafaza yolunu izlemektedir. Her birinin kendi içinde kişisel verilerin korunması hususunda eleştirilecek noktaları bulunmakla birlikte, hiçbiri S. ve Marper kararı öncesinde Birleşik Krallık tarafından uygulandığı şekilde, doku örneklerini süresiz olarak saklamak şeklinde ağır bir temel hak ihlâli yolunu izlememiştir. Bu tablo karşısında, özel nitelikli kişisel verilerin korunması bağlamında, temel hak ve özgürlüklere ilişkin ihlâl teşkil edebilecek unsurların, AİHM incelemesi aranmaksızın gözden geçirilip düzeltilmesi, henüz DNA veri bankasına sahip olmayan ülkelerin ise, suçlarla etkin bir şekilde mücadele gayesiyle hareket ederken, diğer yandan da kişisel verilerin korunması hususunda en yüksek standartları sağlayabilmek adına, mukayeseli hukuktaki örnekleri dikkatlice incelemek suretiyle yasal düzenleme yapması ve bunları hayata geçirmesi gerekmektedir.

\section{Sonuç}

DNA, üç harften ibaret bir kısaltma olan, ancak yapısında sonsuz bilgiler barındıran ve yapılacak moleküler genetik incelemeler sonucunda, sahibine ait özel nitelikli kişisel verileri ortaya koyan bir oluşumu ifade etmektedir. Ceza muhakemesi hukuku bağlamında ele alındığında ise, kişinin değiştiremeyeceği ve bu yüzden de özellikle suç faillerinin tespit edilmesi hususunda adlî makamlara büyük bir avantaj sağlayan önemli bir delil çeşidi teşkil etmektedir.

Türk ceza muhakemesi hukuku açısından, moleküler genetik inceleme yapılabilmesinin önkoşulu, beden muayenesi hükümleri gereğince vücuttan örnek

144 National DNA Data Bank Annual Report 2017-2018 <http://www.rcmp-grc.gc.ca/pubs/nddb-bndg/indexeng.htm> accessed 23 July 2019. 
alınmasıdır. Bu nedenle, CMK'da moleküler genetik inceleme yapılabilecek suçlar açısından herhangi bir kısıtlama getirilmemiş olmasına rağmen, üst sınırı iki yıldan daha az hapis cezasını gerektiren suçlarda, kişi üzerinde iç beden muayenesi yapılamayacağını, kişiden kan veya benzeri biyolojik örnekler ile saç, tükürük, tırnak gibi örnekler alınamayacağını belirten CMK md. 75/5 hükmü gereğince, moleküler genetik inceleme yöntemine başvurulabilmesi için de ortada yaptırım olarak en azından iki yıldan daha fazla hapis cezasının öngörüldüğü bir suç bulunması gerekmektedir.

Moleküler genetik inceleme yöntemine başvurulabilmesi açısından şüphesiz ki işlenen suçun niteliği de önem taşımaktadır. Hayata ve vücut dokunulmazlığına karşı suçlar ya da cinsel dokunulmazlığa karşı suçlar açısından bu yöntemin uygulanması önemli ve elde edilebilecek deliller bakımından daha uygun olacak iken, ceza kanununda düzenlenen kimi suçların niteliği açısından bu yönteme başvurmak mümkün olmayabilecektir. Bu bakımdan örneğin zimmet, ihaleye fesat karıştırma ya da suç işlemek amacıyla örgüt kurma gibi suçlarda DNA'ya ilişkin veri elde edilmesi, çok istisnai durumlar haricinde mümkün olmayacaktır.

CMK'da yer verilen düzenlemeleri, diğer kanun ve yönetmelikler ile bağlantıl1 olarak incelediğimizde, moleküler genetik inceleme yöntemine başvurulması sonucunda ortaya çıkan özel nitelikli kişisel verilerin korunması hususunda önemli mekanizmaların benimsendiği görülmektedir. CMK'da öngörülen zorunluluk ve amaca bağlılık ilkeleri bu açıdan önem taşımaktadır. Moleküler genetik incelemeler, yukarıda ilgili bölümlerde izah edildiği üzere yalnızca zorunluluk durumlarında ve kanunda belirtilen amaçların gerçekleştirilebilmesi uğruna başvurulabilen bir yöntem teşkil etmektedir. Bu iki ilke kabul edilerek uygulama kapsamına yönelik bir kısıtlama da getirilmiş olmaktadır. Bununla birlikte, hem CMK' da hem Yargıtay kararlarında görüldüğü üzere, moleküler genetik inceleme yapılabilmesi için mutlaka hâkim kararı bulunması gerekmektedir. Temel hak ve özgürlüklere ilişkin bir müdahalenin bu şekilde hâkim kararına bağlanmış olması bir gerekliliktir ve bu açıdan kanaatimizce düzenleme yerindedir.

Diğer yandan, moleküler genetik inceleme yapacak olan bilirkişinin objektifliğinin sağlanması ve inceleme yapılması bakımından getirilen yükümlülükler, inceleme sonuçlarının gizliliğine ilişkin düzenlemeler ve verilerin imhasına dair hükümler hep birlikte değerlendirildiğinde, özel nitelikli kişisel veriler açısından önemli bir koruma sağlandığı görülecektir. Ancak elbette ki, önemli olan, gerçek anlamda bir hukuki korumanın sağlanmasıdır ve bunun için sadece yazılı kurallar getirilmesi yetmeyip hukuka bağlılık anlayışı ile bunların uygulanması gerekmektedir. 
DNA verileri yoluyla çözüme ulaştırılabilecek ağır nitelikli suçlar dikkate alındığında, moleküler genetik inceleme yönteminin önemi daha da anlaşılır hâle gelmektedir. Fakat moleküler genetik inceleme yönteminin, biyoteknolojik ilerlemelerden faydalanmak suretiyle, ceza muhakemesinin amaçlarına ulaşabilmesi bakımından daha etkin olmasını sağlayacak yöntem, mukayeseli hukukta gelişmiş ülkelerde gördüğümüz üzere, ülkemizde de ulusal DNA veri bankası kurulması olacaktır. Elbette ki bu veri bankaları, özel nitelikli kişisel verileri konu edindiğinden, hassas bir yaklaşım sergilenmesi ve en üst hukuki korumayı sağlayacak şekilde düzenleme yapılması gerekmektedir. Zira ancak bu şekilde, demokratik bir toplumda, toplumun çıkarları ile bireylerin çıkarları arasında olması gereken denge sağlanabilecektir.

$\mathrm{Bu}$ bakımdan hatırlatmak gerekir ki, bir kişiden alınan hücre örnekleri ile bu örneklerin incelenmesi sonucu oluşturulan DNA profilleri birbirinden farklı hususları ifade etmektedir. Moleküler genetik inceleme sonucu oluşturulan profil daha sonra değiştirilemezken ve üzerinde yeni incelemeler yapılamazken, hücre örneklerinin saklanması durumunda yeni incelemeler yapılması, gelişen tıp ve teknoloji uygulamaları sonucu belki de bugün için bilinemeyen yeni sonuçlara varılması dahi mümkün olabilecektir. Bu nedenle de, özel nitelikli kişisel verilerine ilişkin koruma isteme hakkına sahip bireylerin, belki kendilerinin bile sahip olmadığı bilgilere başkaları tarafından erişilmesi imkânı sağlayan DNA örneklerini devlete belirsiz koşullarda teslim etmesini beklemek, hukuk devleti ilkeleri açısından mümkün olmayacaktır.

İşte bu sebeple atılması gereken ilk adım, ulusal DNA veri bankası kurulması için yasal bir dayanak hazırlanması olacaktır. Bu amaçla hazırlanacak bir kanunun, daha evvel hazırlanan, ancak kadük hâle gelen tasarının eleştirilen yanlarını dikkate alarak oluşturulması gerekmektedir. Üstelik, yalnızca kadük tasarıya ilişkin eleştirilerin değil, uzun yıllardır ulusal DNA veri bankalarına sahip olan ülkelerin mevzuatının ve uygulamalarının, ayrıca konuya ilişkin AİHM içtihatları ile belirlenen hususların yakından incelenmesi önem arz etmektedir. Zira yalnızca bu şekilde hem bireylerin temel hak ve özgürlüklerine dair bir ihlâl meydana gelmemesi hem de ceza muhakemesinde biyoteknolojinin sunduğu imkânlardan genişşekilde yararlanılması, ayrıca uluslararası standartlara erişilmesi ve hatta bunların ilerisine geçilmesi mümkün olabilecektir.

Hazırlanacak olan yasa tasarısında, özel nitelikli kişisel verilerin korunmasının asla ikinci planda kalmış bir amaç olarak görülmemesi gerekmektedir. Bu nedenle, her yönüyle büyük sakıncalar meydana getiren bir uygulama olan ve AİHM'in S. ve 
Marper kararı öncesine kadar Birleşik Krallık tarafından uygulandığı şekliyle, DNA hücre örneklerinin saklanması değil, yalnızca moleküler genetik inceleme sonucu oluşturulan profillerin saklanması esas alınmalıdır. Yasal bir dayanağın mevcudiyetinin ardından, dikkat edilmesi gereken ilk ve en önemli husus bu olmalıdır.

AİHM kararlarını incelediğimizde görülmektedir ki mahkeme, DNA profillerinin saklanmasını suçla mücadele açısından olumlu bir husus olarak değerlendirmektedir, fakat bu uygulamanın kişisel verilerin korunması amacını ön planda tutacak şekilde, yalnızca belirli ağırlıktaki suçlar açısından söz konusu olacak ve suistimallere izin verilmeyecek şekilde düzenlenmesi gerektiğini kabul etmektedir. Bu nedenle, hangi suçların faillerine ait DNA profillerinin sistemde saklanacağının belirlenmesi önem taşımaktadır. Ayrıca verilerin hangi koşullarda saklanacağı, bilgilere kimlerin nasıl erişeceği, kişisel verilerin korunması açısından yaşanabilecek ihlâllere karşı nasıl önlemler alınacağı ve herhangi bir ihlâl söz konusu olması durumunda uygulanacak yaptırımlar net bir şekilde belirtilmelidir.

Kanaatimizce, mukayeseli hukukta incelediğimiz uygulamalardan, ABD'de söz konusu olduğu gibi, DNA veri bankasına yetkisiz kişilerin girmesi veya özel nitelikli kişisel verilerin korunmasına ilişkin herhangi bir ihlâl yaşanması durumunda, yüksek miktarda para cezasının da dâhil olduğu caydırıcı cezaların uygulanması gerekmektedir. Ülkemizde DNA veri bankası kurulması durumunda, burada saklanacak olan profillerin, kişisel verilerin korunmasına ilişkin hükümler kapsamında dolaylı olarak korunması ile yetinilmeyip doğrudan doğruya bu yönde gerçekleşebilecek ihlâllerin ayrı bir suç olarak düzenlenmesi daha uygun olacaktır. DNA veri bankasında saklanan veriler bakımından herhangi bir bilgi sızıntısı olursa veya bu bilgiler amaç dışında ya da kötüye kullanılırsa, temel hak ve özgürlükler açısından çok ağır ihlâllere yol açacağından, öngörülecek yaptırımların da aynı ağırlıkta olması gerekmektedir. Görevi dolayısıyla bu verilere erişim kolaylığına sahip bulunan kişilerin fail olması durumunun da cezayı ağırlaştırıcı nitelikli bir hâl olarak kabul edilmesi gerekmektedir.

DNA veri bankası kurulması bakımından dikkate değer bir diğer uygulama ise, Kanada tarafından detaylı şekilde uygulanan tasnif yöntemi olmaktadır. Gerçekten de, hükümlülere, gönüllülere, kadınlara ve erkeklere ait DNA profillerine ilişkin farklı endeksler oluşturulması, amaca ulaşmak bakımından büyük fayda sağlayacak bir usul teşkil etmektedir. Bu yöntem ile hız ve kolaylığın yanında, araştırma konusu olan suçun kapsamı dışında kalan kişilerin özel nitelikli kişisel verilerinin korunması da sağlanmış olacaktır. 
Üzerinde durulması gereken bir başka önemli konu da DNA veri bankasında saklanan profillerin silinmesini talep etme hakkının tanınması gerekliliğidir. Bu husus, AİHM'in Fransa aleyhine hüküm verdiği Aycaguer v. Fransa kararında açıkça belirtilmiştir. Hangi durumlarda verilerin silineceği kanun ile belirlense dahi, gerekçelerini sunmak koşulu ile kişilere ayrıca ve açıkça bilgilerinin silinmesini talep etme hakkı tanınmalıdır.

Görüldüğü üzere, konunun kapsamı ve hassasiyeti, yapılacak olan değerlendirmelerin de aynı doğrultuda kapsamlı ve hassas olmasını gerektirmektedir. Doktrinimizde genel olarak DNA veri bankası kurulması gerektiği görüşü yer alsa da konuya çekinceyle yaklaşanlar da bulunmaktadır. Eşleştirme yöntemiyle suç faillerinin tespit edilmesini kolaylaştırmak bakımından büyük fayda sağlayacak olan bu oluşum, özel nitelikli kişisel verilerin korunması konusunda gereken özen gösterildiği takdirde, herhangi bir olumsuzluğa yol açılmadan hukukumuza dâhil edilebilecektir. Üstelik esas amaçlarla kıyasla geri planda kalan, ama yine de önem taşıyan bir husus da saklanan DNA profilleri sayesinde kimliğinin kolayca tespit edilebileceğini bilen suç failleri açısından meydana gelecek caydırıcılık etkisi olacaktır.

Neticede, bireylerin temel hak ve özgürlüklerinin korunması beklentisi ile toplumun çıkarları arasında orantılılık sağlanması noktasında, tüm kişisel verilerin, fakat en çok da özel nitelikli kişisel verilerin korunması açısından, akıllarda herhangi bir soru işareti bırakmayacak tedbirler alındıktan uygulamaya geçmek gerekmektedir. Bu nedenle, DNA örnekleri üzerinde yapılan moleküler genetik incelemelerin yasada belirlenen esaslara uygun şekilde gerçekleştirilmesi, gelecek açısından ise, ulusal DNA veri bankası kurulması ihtiyacının giderilmesi durumunda, uzun yıllardır bu veri bankalarından faydalanan ülkelerin mevzuatı ve uygulamaları detaylı şekilde incelenmek suretiyle, uluslararası standartların da üstüne çıkılarak örnek bir modelin hayata geçirilmesi gerekmektedir.

Finansal Destek: Yazar bu çalışma için finansal destek almamıştır.

\section{Kaynakça}

Aksoy İpekçioğlu, P, ‘Vücuttan Örnek Alma İşleminin Hukuki Niteliği ve Anayasaya Uygunluğu’ Prof. Dr. Nur Centel'e Armağan (Beta Yayınları, İstanbul 2013) 1157-1175.

Annas, George J, 'Protecting Privacy and the Public-Limits on Police Use of Bioidentifiers in Europe' (2009) 361 (2) The New England Journal of Medicine, 196-201.

Apiş, Ö, ‘Ceza Muhakemesi Hukukunda Şüpheli/Sanığın Beden Muayenesi ve Vücudundan Örnek Alınması’ (2012) 18 (1) MÜHFHAD 267-296.

Arısoy, Y / Eresen, Ç / Özbek, V. Ö, 'Yeni Yasal Düzenlemeler ve Moleküler Genetik İncelemeler' (2008) 28 (2) Türkiye Klinikleri Journal of Medical Sciences 178-181. 
Aydın, S. E, AİHM İçtihatları Bağlamında Kişisel Verilerin Kaydedilmesi Suçu (On İki Levha Yayıncılık, İstanbul 2015).

Aygörmez Uğurlubay, G. A, 'Almanya, İsviçre ve Avusturya Hukuku Bağlamında Türk Ceza Muhakemesi Hukukunda Adli DNA Analizleri’ (2017) 5 (2) Ceza Hukuku ve Kriminoloji Dergisi (Journal of Penal Law and Criminology) 29-87.

Batur, N, ‘Ceza Yargılamasında Moleküler Genetik İnceleme’ (2016) 126 TBB Dergisi 69-94.

Biondo, R / De Stefano, F, 'Establishment of Italian national DNA database and the central laboratory: Some aspects', (2011) 3 (1) Forensic Science International: Genetics Supplement Series 236-237.

Bozlak, A, Avrupa İnsan Hakları Mahkemesi Kararları Çerçevesinde Türk Ceza Hukukunda Özel Hayatın Korunmast (Adalet Yayınevi, Ankara 2013).

Bulak Uygun, B, 'Databases and Criminal Procedures in Switzerland and Turkey with Regard to European Council's Standarts' (2017) 5 (2) Ceza Hukuku ve Kriminoloji Dergisi (Journal of Penal Law and Criminology) 89-106.

Büken, E, 'Adli Tipta Genetik Araştırmalar' (2009) 22 İKU (İyi Klinik Uygulamalar) Dergisi 33-42.

Centel, N / Zafer, H, Ceza Muhakemesi Hukuku (Beta, İstanbul 2018).

Combined DNA Index System (CODIS) of FBI

$<$ https://www.fbi.gov/services/laboratory/biometric-analysis/codis/codis-and-ndis-fact-sheet $>$

$<$ http://www.fbi.gov/about-us/lab/biometric-analysis/codis $>$

Convention for the Protection of Individuals with regard to Automatic Processing of Personal Data (ETS No 108) $<$ http://conventions.coe.int/Treaty/en/Treaties/Html/108.htm>

Donay, S, Ceza Muhakemesi Kanunu Şerhi (Beta, İstanbul 2009).

Elmas, I / Ersoy, G, 'Adli Olgulardan Biyolojik Örnek Alınması ve Moleküler Genetik İncelemelerde Yasal Boyut' (2009) 22 Klinik Gelişim Dergisi Adli Tıp Özel Sayısı 111-113.

Erbaş, R, 'The Tension between Genome Privacy and Criminal Justice in the Wake of DNA Databases' (2017) 5 (2) Ceza Hukuku ve Kriminoloji Dergisi (Journal of Penal Law and Criminology) 163-178.

European Commission, <https://ec.europa.eu/info/law/law-topic/data-protection/reform/what-personal-data_en>

Gödekli, Mehmet, 'Türk Ceza Muhakemesinde Maddi Gerçeğe Ulaşmanın Ön Koşulu Olarak Hukuka Aykırı Delillerin Değerlendirilmesi Yasağı' (2016) 65 (3) Ankara Üniversitesi Hukuk Fakültesi Dergisi 1815-1924.

Gökcen, A / Balcı, M / Alşahin, M. E / Çakır, K, Ceza Muhakemesi Hukuku (Adalet Yayınevi, Ankara 2018).

Gözübüyük, Ş / Gölcüklü, F, Avrupa İnsan Hakları Sözleşmesi ve Uygulaması (Turhan Kitabevi, Ankara 2009).

Graham, E. A. M, 'DNA reviews: the national DNA database of the United Kingdom' (2007) 3 (4) Forensic Science, Medicine, and Pathology 285-288.

Haines, P, 'Embracing the DNA Fingerprint Act' (2007) 5 Journal on Telecommunications and High Technology Law 629-665.

Hancı, H / Kocaoğlu, S. S, 'Savunma Adli Tıp Akademisi TBB-ATA’Adli Tıp ve Ceza Hukuku (Seçkin Yayıncılık, Ankara 2012).

HUDOC European Court of Human Rights, <https://hudoc.echr.coe.int/eng\#\{“ documentcollectionid2":[“GRANDCHAMBER","CHAMBER”]\}>

Kazancı İçtihat Bilgi Bankası, http://www.kazanci.com/kho2/ibb/giris.html

Kılınç, D, ‘Anayasal Bir Hak Olarak Kişisel Verilerin Korunması' (2012) 61 (3) AÜHFD 1089-1169.

Kızılarslan, H, 'Hukuka Aykırı Delil Açısından Vücudun Muayenesi ve Örnek Alma İşlemleriyle İlgili 5271 S. CMK Düzenlemesi ve Uygulamada Sorunlar' Ceza Muhakemesi Kanununun 3 Y1lı (TCHD Yayınları No 11, İstanbul 2009).

Kızılarslan, H, Vücudun Muayenesi \& Örnek Alma (Kızılarslan Serisi I, Ankara 2007).

Kunter, N / Yenisey, F / Nuhoğlu, A, Açıklamalı Ceza Muhakemesi Kanunu (Beta, İstanbul 2013). 
Küzeci, E, Kişisel Verilerin Korunması (Turhan Kitabevi, Ankara 2010).

Mahmutoğlu, F. S, 'Beden Muayenesi ve Vücuttan Örnek Alınması', <http://fsmahmutoglu.av.tr/ pdf/76b00da1de336791f454b4977f6319d9cdf4656d7818071225.pdf>

Mahmutoğlu, F. S, 'Moleküler Genetik İncelemenin Ceza Yargılaması Hukuku Bağlamında Analizi', <http:// fsmahmutoglu.av.tr/pdf/27b485a20728432f3c6b2f169f7a8f80c 62998517818071225.pd>

Mumcu, A / Küzeci, E, İnsan Haklarl ve Kamu Özgürlükleri (Turhan Kitabevi, Ankara 2011) .

National DNA Data Bank of Canada Annual Report of 2017-2018<http://www.rcmp-grc.gc.ca/pubs/nddb-bndg/ index-eng.htm>

Napper, Robin, 'A National DNA Database the United Kingdom Experience' (2000) 32 (2) Australian Journal of Forensic Sciences 65-69.

Özbek, V. Ö, ‘Ceza Muhakemesi Hukukunda DNA Analizi’, <http://www.hukuki.net/ www.saglikhukuku.net/ bilgi/a044.asp>

Özbek, V. Ö, 'DNA Verileri ve Türkiye Milli DNA Veri Bankası Kanunu Tasarısı Hakkındaki Görüşlerimiz' (2007) 1 Ceza Hukuku Dergisi 47-76.

Özbek, V. Ö, ‘Tıp Ceza Hukukunda DNA İncelemesi’ V. Türk-Alman Tıp Hukuku Sempozyumu-Tıp Ceza Hukukunun Güncel Sorunları (Türkiye Barolar Birliği Yayınları, Ankara 2008).

Özbek, V. Ö, Ceza Muhakemesi Hukuku (Seçkin Yayıncılık, Ankara 2006).

Özbek, V. Ö, CMK İzmir Şerhi (Seçkin Yayıncılık, Ankara 2005).

Öztürk, B / Tezcan, D / Erdem, M. R et al, Nazari ve Uygulamalı Ceza Muhakemesi Hukuku (Seçkin, Ankara 2018).

Parlar, A / Hatipoğlu, M, 5271 Sayılı Ceza Muhakemesi Kanunu Yorumu, vol 2 (Ankara 2008).

Polat, O, Klinik Adli Tıp (Seçkin Yayıncılık, Ankara 2007).

Santos, F / Machado, H / Silva, S, 'Forensic DNA Databases in European Countries: Is Size Linked to Performance?' (2013) 9 (12) Society and Policy <http://www.lsspjournal.com/content/9/1/12>

Santos, F/ Machado, H, 'Patterns of Exchange of Forensic DNA Data in the European Union Through the Prüm System’ (2017) 57 (4) Sci Justice 307-313.

Schroeder, F. C / Verrel, T, Ceza Muhakemesi Hukuku, (Salih Oktar trs, Yetkin Yayınları, Ankara 2019).

Semizoğlu, İ, Adli DNA Analizleri (Adalet Yayınevi, Ankara 2013).

Soyaslan, D, Ceza Muhakemesi Hukuku (Yetkin Yayınevi, Ankara 2018).

Suterwalla, A, 'Collection and Retention of Personal Data', in Human Rights in the Investigation and Prosecution of Crime (Oxford University Press, Oxford 2009) 185-206.

Swergold, J. M, 'To Have and To Hold: The Future of DNA Retention in the United Kingdom' 33 (1) Boston College International and Comparative Law Review 179-200.

Şahin, C / Göktürk, N, Ceza Muhakemesi Hukuku II (Seçkin Yayıncılık, Ankara 2019).

TC Anayasa Mahkemesi, Kararlar Bilgi Bankası, <https://www.anayasa.gov.tr/tr/kararlar-bilgi-bankasi/> (2015/32 E 2015/102 K sayılı ve 12/11/2015 tarihli karar).

TC Resmî Gazete, <http://www.resmigazete.gov.tr/> (01/06/2005 Tarih, 25832 Sayı ve 22/07/2005 Tarih, 25883 Say1).

Topçu, N. K, Ingiliz Ceza Muhakemesi Hukukunda Soruşturma Evresi (Adalet Yayınevi, Ankara 2018).

Tuğ, A, 'Adli DNA Bankalarına Toplumun Yaklaşımı' (2007) 21 (2) Adli Tıp Dergisi 1-10.

Turhan, F, ‘Ceza Muhakemesinde Beden Muayenesi ve Tıp Hukuku (Özellikle AİHM Kararları Işı̆̆ında Şüpheli veya Sanığın Zorla Muayenesi Konusunun Değerlendirilmesi)’ V. Türk-Alman Tıp Hukuku SempozyumuTıp Ceza Hukukunun Güncel Sorunları (TBB Yayınları, Ankara 2008).

Turhan, F, Ceza Muhakemesi Hukuku (Asil Yayın Dağıtım, Ankara 2006). 
Türk Tabipler Birliği, <http://www.ttb.org.tr/haberarsiv_goster.php?Guid=665acfee-9232-11e7-b66d$1540034 \mathrm{f} 819 \mathrm{c}>$

Uygun, O, Kamu Hukuku İncelemeleri (XII Levha Yayıncılık, İstanbul 2011).

Ünver, Y / Hakeri, H, Ceza Muhakemesi Hukuku (Adalet Yayınevi, Ankara 2018).

Ünver, Y / Hakeri, H, Ceza Muhakemesi Hukuku, vol 1 ( $8^{\text {th }}$ Edn, Adalet Yayınevi, Ankara 2013).

Wallace, H, 'The UK National DNA Database: Balancing crime detection, human rights and privacy' (2006) 7 EMBO Reports 26-30.

Yaşar, O, Yeni İçtihatlarla Uygulamalı ve Yorumlu Ceza Muhakemesi Kanunu vol 1 (Seçkin Yayınları, Ankara 2011).

Yenisey, F / Oktar, S, Alman Ceza Muhakemesi Kanunu Strafprozeßordnung (StPO) Almanca Metin-Türkçe Çeviri (2 ${ }^{\text {nd }} \mathrm{Ed}$, Beta, İstanbul 2015)

Zöller, M. A / Thörnich, D, 'Rechtliche Möglichkeiten und Grenzen der Ausweitung von DNA-Analysen im Strafverfahren’ (2017) 6 ZIS 331-340. 